Board of Governors of the Federal Reserve System

International Finance Discussion Papers

Number 675

July 2000

\title{
DO INDICATORS OF FINANCIAL CRISES WORK? AN EVALUATION OF AN EARLY WARNING SYSTEM
}

\author{
Hali J. Edison
}

NOTE: International Finance Discussion Papers are preliminary materials circulated to stimulate discussion and critical comment. References to International Finance Discussion Papers (other than an acknowledgment that the writer has had access to unpublished material) should be cleared with the author or authors. Recent IFDPs are available on the Web at www.bog.frb.fed.us. 


\title{
DO INDICATORS OF FINANCIAL CRISES WORK? \\ AN EVALUATION OF AN EARLY WARNING SYSTEM
}

\author{
Hali J. Edison*
}

\begin{abstract}
The object of this paper is to develop an operational early warning system (EWS) that can detect financial crises. To achieve this goal the paper analyzes and extends the early warning system developed by Kaminsky, Lizondo, and Reinhart (1998) and Kaminsky and Reinhart (1999) that is based on the "signal" approach. This system monitors several indicators that tend to exhibit an unusual behavior in the periods preceding a crisis. When an indicator exceeds (or falls below) a threshold, then it is said to issue a "signal" that a currency crisis may occur within a given period. The model does a fairly good job of anticipating some of the crises in 1997/1998, but several weaknesses to the approach are identified. The paper also evaluates how this system can be applied to an individual country. On balance, the results in this paper are mixed, but the results suggest that an early warning system should be thought of as a useful diagnostic tool.
\end{abstract}

Keywords: Currency crises, vulnerability indicators, Asian crisis, balance of payments crisis, crisis prediction

JEL Classification: F31, F47

\footnotetext{
*The author is a senior economist in the Division of International Finance. The views in this paper are solely the responsibility of the author and should not be interpreted as reflecting the views of the Board of Governors of the Federal Reserve System or of any other person associated with the Federal Reserve System. The author thanks Andrew Berg, Neil Ericsson, Jon Faust, William Helkie, David Hendry, David Howard, Steven Kamin, Graciela Kaminsky, Catherine Pattillo, Carmen Reinhart, and Jonathan Wright for helpful comments and discussion. Research assistance by Pao-Lin Tien, Hayden Smith, and Michael Sharkey is greatly appreciated.
}

Correspondence to Hali J. Edison, Stop 24, Federal Reserve Board, Washington, D.C. 20551. Telephone: +1-202- 452-3540, Fax: +1-202-452-6424 Email: hali.edison@frb.gov 


\section{Introduction}

The financial crises that erupted in east Asia in the second half of 1997 after the devaluation of the Thai baht are the latest in a series of episodes of financial turmoil. In the 1990s, currency crises have occurred in Europe (the 1992-1993 crises in the European Exchange Rate Mechanism), in Latin America (the 1994-1995 peso crisis) and in Asia, Russia, and once again in Latin America. ${ }^{1}$ Financial crises have a large impact on the real economy, especially a loss in output, and frequently the effects have spilled over to other economies. There is reason to believe that many of the same forces have been at work in different crises, including the buildup of unsustainable fiscal and external imbalances and the misalignment of asset prices, especially exchange rates. In view of the large costs that economies undergo in a financial crisis, the challenge some crises may pose to the international financial system and more generally, the sense that there may be common elements underlying financial crises, researchers have been focusing on developing models that could help policymakers anticipate problems and react appropriately.

This study develops, evaluates and attempts to improve upon an econometric model known as an "early warning system" (EWS) - that may be used to help anticipate crises. The purpose of this paper is to determine the extent to which implementation of an early warning system would enhance our capacity to identify future trouble spots among emerging market countries.

What is an early warning system? An early warning system consists of a precise

\footnotetext{
${ }^{1}$ See Kamin (1999) for a comparison of the scope and impact of three emerging market financial crises since 1982.
} 
definition of a crisis and a mechanism for generating predictions of crises. ${ }^{2}$ Different researchers have adopted alternative approaches to address a number of conceptual and practical issues that arise concerning both the definition of a crisis and the means of predicting it.

In this paper a crisis is defined as an episode in which an attack on the currency leads to a sharp depreciation of the currency, a large decline in international reserves, or a combination of both these effects. The definition is intended to be comprehensive, including successful and unsuccessful attacks on the currency under different exchange rate regimes, including fixed exchange rates, crawling pegs or exchange rate bands.

To generate predictions this paper uses the "signal extraction" approach, following the work of Kaminsky, Lizondo, and Reinhart (1998) [henceforth KLR], Kaminsky and Reinhart (1999)[henceforth KR], and Berg and Pattillo (1999a and 1999b) [henceforth BP]. This system involves monitoring the evolution of a number of economic indicators that tend to behave systematically differently prior to a crisis and determining whether these indicators have reached levels historically associated with heightened probabilities of a future crisis.

The innovations I make in this paper are modest. First, I expand the country coverage and add several explanatory variables. Second, I examine regional differences and test the robustness of the results to changes in crisis definition. Third, I consider the performance of this algorithm for an individual country. Fourth, I compare the existing algorithm with a similar, but simpler, algorithm that does not require information using other countries.

The results of my empirical work confirm prior findings that historically countries that

\footnotetext{
${ }^{2}$ Some authors, especially Berg and Pattillo, have stressed predicting a crisis. In this paper I strive to stress that the goal of the early warning system is to identify countries that need to be scrutinized further. The distinction is essentially a matter of semantics. In fact, at times I use the two terms: predicting a crisis and a country entering a zone of vulnerability - interchangeably.
} 
have come under attack tend to share a number of common characteristics. Furthermore, the Asian economies, according to the early warning system I develop, exhibited signs of vulnerability months before the crisis started in July 1997 . This result suggests that an early warning system offers some guidance in systematically analyzing the data and helps to identify zones of vulnerability. On the other hand, the model frequently missed crises or predicted crises that did not occur. These results suggest that these models, while useful as a diagnostic tool, must be complemented by more standard country surveillance and cannot substitute for such surveillance.

The paper is organized as follows. Section 2 provides a brief description of the related literature. Section 3 addresses the design of the system, describing the scope of the model, presenting the definition of a currency crash, and explaining the statistical methods. Section 4 implements the KLR approach and describes my replication of their 1970 - 1995 early warning system. Section 5 augments the KLR model, creating my benchmark model, and then evaluates the in-sample performance of the benchmark indicators and calculates the out-of-sample probabilities of a crisis. Section 6 provides a case study, using Mexico as an example, while section 7 considers aspects of the robustness of the findings. Finally, section 8 presents the conclusions.

\section{Related Literature}

Since the collapse of the European exchange rate mechanism (ERM), many studies have focused on modeling currency crises using multi-country data sets. Most of these studies divide the sample into periods of tranquility and periods of turbulence, but then use different econometric techniques, including event studies, probit analysis, and signal-extraction methods. 
Selected papers are discussed below.

This empirical literature on currency crises using multi-country data was pioneered by Eichengreen, Rose, and Wyplosz in a series of papers $(1994,1995,1996)$ [hereafter ERW]. ERW (1994 and 1995) focus on industrialized countries that peg, or had pegged, their exchange rates. ERW define a crisis as large movements in exchange rates, interest rates, and international reserves and then compare the behavior of a number of macroeconomic variables during crisis and tranquil periods. They find that the behavior of key macroeconomic variables for ERM countries vary across periods, but that these differences do not appear for non-ERM countries. These findings lead them to conclude, unlike many of the subsequent papers in the literature, that there are no clear early warning signals of speculative attacks.

Frankel and Rose (1996) [hereafter FR] shift the focus of this literature towards modeling currency crashes for developing countries using probit analysis on a panel of annual data for 105 countries from 1971 to 1992 . Their definition of a currency crisis differs from ERW in that they focus only on large exchange rate movements. FR's use of annual data permits them to look at variables such as the composition of external debt that are only available at that frequency. FR find that low levels of foreign direct investment, low international reserves, high domestic credit growth, high foreign interest rates, and the overvaluation of the real exchange rate increase the probability of a currency crash. These significant results lead FR to conclude that their model would provide an early warning of a currency crisis.

Following the Mexican crisis, Kaminsky and Reinhart (1999) develop an early warning system model to consider currency and banking crises, analyzing the links between the two. In a series of subsequent papers, Kaminsky, Lizondo, and Reinhart (1998) and Goldstein, Kaminsky 
and Reinhart (2000) [henceforth GKR] extend that research. Their work focuses on a mix of developed and emerging market economies - roughly 20 countries - using monthly data from 1970 to $1997 .{ }^{3}$ Each of these studies uses the signal extraction approach assessing the evolution of many macroeconomic and financial variables around the time of the crisis. They find that the overwhelming majority of crises have numerous weak economic fundamentals at their core, including a slowdown in economic activity, an overvalued exchange rate, reserve loss, and high ratio of broad money (M2) to international reserves. These findings lead the authors to conclude that banking and currency crises in emerging markets do arrive with some early warnings. The predictive power of their model is greater for currency crises than for banking crises.

Berg and Pattillo (1999a, b, and c) and Masson, Borensztein, Berg, Milesi-Ferretti and Pattillo (2000) in a series of papers evaluate existing models and develop an "improved" early warning model for use at the IMF. The first two papers by BP (1999a and 1999b) evaluate and compare the predictive powers of three models including those developed by FR, Sachs, Tornell and Velasco (1996), and KLR. In particular, these papers evaluate the models by posing the question: if the IMF had been using these models in 1996, how well would they have been able to predict the Asian crisis. In conducting the experiment, they augment the KLR model by adding a few additional explanatory variables and by adjusting slightly the countries included in their sample. In addition, they embed the KLR variables in a multivariate probit model and compare this model with the KLR model results. The subsequent BP papers and Masson et al paper refine the multivariate probit model first developed in BP (1999a). The two main refinements the authors make are: to limit the model to five explanatory variables and to include

\footnotetext{
${ }^{3}$ GKR expand the KLR sample of countries to 25 and extend the data through 1998.
} 
the ratio of short-term debt (as provided by the BIS) to reserves as one of these explanatory variables. This parsimonious model, though yielding mixed results, is currently being used informally to update IMF management.

In addition to these studies, the private sector has also produced research to help forecast the probabilities of large currency depreciations. A model by Goldman Sachs (GS), which has received considerable attention, uses a hybrid of the BP and KLR approach. They rely on discrete indicator variables which are then embedded in a probit equation. The performance of the GS model has been quite reasonable signaling crises at the short horizon ( 3 months) for Brazil, Ecuador, and Turkey. However the model failed to predict the significant pressure on the Colombian currency.

\section{Implementation of an Early Warning System}

The design of an early warning system requires considering the scope of the model (country coverage, choice of explanatory variables, and time dimensions), the definition of a crisis (the statistical dating of the crises) and the statistical methodology (signal extraction versus probit analysis). In this paper, for the most part, I have followed the framework of Kaminsky, Lizondo and Reinhart, deviating at times to improve the model's performance. This section discusses the implementation of their model.

\subsection{Scope of the Model}

The first set of issues relates to defining the scope of the model. Even though many of these issues are fairly basic, such as single country analysis versus multi-country analysis, the decisions made can influence the overall results.

\section{Country Coverage}


Most recent empirical studies of crises examine the experience of several countries over many crisis episodes. For a country to be included in an empirical study, it usually has to have experienced at least one financial crisis. This selection criteria could introduce some "selection" bias, but with a large and diverse sample this bias should be relatively small. Initially, I examine the twenty countries, both developed and emerging market economies, used in KLR. These twenty countries form three regional groups: Latin America (Argentina, Bolivia, Brazil, Colombia, Chile, Mexico, Peru, Uruguay, and Venezuela), Asia (Indonesia, Malaysia, the Philippines, and Thailand) and other (Denmark, Finland, Israel, Norway, Spain, Sweden and Turkey). ${ }^{4}$ Section 5 expands the sample to include several additional emerging market economies that have experienced a financial crisis during the sample period under consideration.

\section{Choice of Indicator Variables}

In the signals approach, which was pioneered by KLR, vulnerability to crisis is signaled when one or more "indicator variable" deviates significantly from its behavior during non-crisis periods. I start the study using the indicator variables reported in the KLR study, which were chosen by theoretical consideration and by their availability on a monthly basis for all countries and time periods. Those variables can be grouped into four major categories: current account indicators, capital account indicators, real sector indicators, and financial indicators. Below is a list of the variables considered:

- Current account indicators: deviations of the real exchange rate from the trend, the value of imports, and the value of exports. ${ }^{5}$

\footnotetext{
${ }^{4}$ Note that Korea was not in the original KLR sample.
}

${ }^{5} \mathrm{KLR}$ use a terms of trade indicator. This variable was not easy to construct consistently across countries and therefore was dropped from the analysis. 
- Capital account indicators: foreign exchange reserves, the ratio of M2 to foreign exchange reserves, and the domestic - foreign real interest rate differential on deposits.

- Real sector indicators: industrial production and index of equity prices.

- Financial indicators: M2 multiplier, the ratio of domestic credit to nominal GDP, the real interest rate on deposits, the ratio of lending-to-deposit interest rates, excess real M1 balances, and commercial bank deposits. ${ }^{6}$

For most of these variables, the monthly value of the indicator was defined as the percentage change in the level of the variable with respect to its level a year earlier. KLR argue that filtering the data by using the 12-month percentage change ensures that the units are comparable across countries and that the transformed variables are stationary, with well-defined moments, and free from seasonal effects. This filter was not used for: the deviation of the real exchange rate from the trend, the "excess" of real M1 balances, and the interest rates variables.

Table 1 provides more information on the indicators used in the basic framework and in the expanded model. ${ }^{7}$ The first column shows the category headings and the second column provides the name of the variable. The third column reports whether high (upper) or low (lower) values of each variable would signal that the economy is vulnerable to a currency crisis. The fourth column briefly summarizes the economic rationale for the variable. For example, Table 1 classifies the deviation of the real exchange rate from the trend - where the real exchange rate is defined as the nominal bilateral exchange rate (foreign currency/dollar) adjusted for relative

\footnotetext{
${ }^{6}$ This study does not consider data on structural problems such as banking, corporate governance, or corruption. Data on these issues are hard to obtain, especially for a large number of countries.

${ }^{7} \mathrm{~A}$ fifth category is reported in Table 1 representing global or external variables. In the expanded model, I consider global variables such as G-7 output, U.S. output, U.S. interest rates and oil prices.
} 
prices - a current account variable. Large misalignments (negative movements) of the real exchange rate are often associated with currency crisis and hence a large negative deviation (real appreciation) of the real exchange rate from the trend is considered a leading indicator. Another example from Table 1 is industrial production, which is catalogued as a real sector variable. Theory suggests that sharp declines (lower tail) in domestic output are often associated with crises.

\section{Time Period}

A third aspect to the scope of the model relates to considerations of timing. There are many dimensions to this issue, including the selection of historical data that are used to calibrate the model, the selection of a crisis window (the time interval over which one is predicting a crisis), and the frequency of the data. The results of our modeling will depend heavily on the choices made here. In this paper I follow the choices made by KLR. The historical data horizon initially is 1970 - 1995, which is then expanded to include data to the end of 1998. The data are reported at monthly frequency and the crisis window is set at 24 months. Section 5 and 7 modify some of these initial selections to examine the robustness of the results.

\subsection{What are we trying to Predict? The Definition of a Currency Crisis}

A second set of issues relates to the identification of a crisis. One question is whether to use a crisis indicator that varies with the severity of the crisis, or whether to adopt a truncated or 0/1 dichotomy (no crisis/crisis). In this paper, following the choices made by many prior researchers, I use the latter approach. A second question is whether to define a crisis on the basis of events in the foreign exchange market alone, or to take a broader set of events into consideration. I follow KLR in identifying a crisis as a period of extreme movements in an 
exchange market pressure index (defined below). Several arbitrary assumptions are made to construct this dating scheme. Consequently in section 7, I examine the robustness of the model results to an alternative dating scheme.

\section{The Operational Definition of a Crisis}

A crisis is defined as a period of extreme pressure in the foreign exchange market. ${ }^{8}$ Following the work of others, an exchange market pressure index is constructed for each country. ${ }^{9}$ The indices are calculated as the weighted average of percent changes in the bilateral nominal exchange rate and the percent change in foreign reserves, with weights such that the two components of the index have equal sample volatility. The exchange market pressure index is as follows: $:^{10}$

$$
e m p_{t}=\% \Delta e_{t}-\alpha_{1} \% \Delta r_{t}
$$

Where $e_{t}$ denotes the foreign currency per numeraire currency (either U.S. dollars or German marks $)^{11}$ at time $t, r_{t}$ denotes foreign reserves, $\alpha_{l}$ is the ratio of the standard deviation of the rate of change of the exchange rate to the standard deviation of the rate of change of reserves (e.g., $\left.\sigma_{e} / \sigma_{r}\right)$. Note that changes in the exchange rate enter with a positive weight and changes in reserves have a negative weight, so that both depreciations of the exchange rate and declines in

${ }^{8}$ Ideally, a measure of this pressure should stem from a model of exchange rate determination. However much research has underscored the inadequacy of exchange rate models.

${ }^{9}$ This is based on the model developed by Girton and Roper (1977).

${ }^{10}$ Eichengreen, Rose, and Wyplosz $(1994,1995,1996)$ in their analysis of currency crises in developed economies include domestic interest rates in this definition. The lack of a consistent set of data for developing countries preclude the inclusion of interest rates in the market pressure index.

\footnotetext{
${ }^{11}$ Most of the sample was prior to EMU and hence the mark was used as the numeraire. After 1999, the numeraire currency became the Euro.
} 
reserves raise the index of exchange market pressure. ${ }^{12}$

A crisis is defined as an event where this index rises above an extreme value:

$$
\begin{aligned}
\text { Crisis } & =1 \text { if } \quad \text { emp }>2.5 \sigma_{\text {emp }}+\mu_{\text {emp }} \\
& =0 \text { otherwise }
\end{aligned}
$$

Where $\sigma_{e m p}$ and $\mu_{e m p}$ are the sample standard deviation and sample mean of emp respectively. A crisis is said to occur when the pressure index is more than 2.5 standard deviations above the mean. ${ }^{13}$ Although the choice of 2.5 as a threshold value is somewhat arbitrary, the cataloging of crises obtained by this method tends to follow closely the chronology of currency market disruptions described in the literature (see KLR and KR).

\section{A look at the Crises Identified}

To give a sense of how these financial pressure indices work, Figure 1 displays the financial pressure index (solid line) for Mexico over the past twenty-five years. The horizontal (dashed) line is the threshold. When the pressure index exceeds this value, it indicates a crisis. In the case of Mexico four episodes are identified: September 1976, February 1982, December 1982, and December 1994. These episodes are consistent with the dates when Mexican currency crises are generally understood to have taken place.

This index of foreign exchange pressure was constructed for each of the 20 countries in

\footnotetext{
${ }^{12}$ Following Kaminsky and Reinhart, for countries in the sample that had hyperinflation the construction of the index was modified. While a 100 percent devaluation may be traumatic for a country with low-to-moderate inflation, a devaluation of that magnitude would not be traumatic during hyperinflation. A single index for countries with hyperinflation episodes would miss sizable devaluations and reserve losses during moderate inflation periods, because the historic mean is distorted by high-inflation episodes. To avoid this problem, the sample is divided according to whether inflation in the previous six months was higher than 150 percent and then constructed an index for each subsample.

${ }^{13}$ KLR and BP use 3 standard deviations rather than 2.5 standard deviations. I found that 2.5 standard deviations lead to the identification of more crises and were more consistent with those of KLR.
} 
the KLR sample over the 1970 - 1995 period. When the index exceeded the threshold as described in equation (2), a crisis was identified. ${ }^{14}$ Figure 2 plots the financial pressure index and the threshold variable for all 20 countries. The index and the threshold vary across countries. It should be noted that those countries that experienced hyperinflation have two threshold levels, one for periods of normal inflation and one for periods of high inflation.

Table 2 shows the distribution of those crises over time, including data on the expanded sample, covering 28 countries from January 1970 to December 1999 . Column 5 reports the aggregate numbers, while columns 2 - 4 give the distribution by region. On this basis, between 1970 and 1999 there were 94 episodes (3.1 per year) in which countries that experienced currency crises were identified. The table does not reveal any secular trend in currency crises. The frequency of crises peaks during the early 1980's, with 5 crises per year in 1980-1984, compared to 2.9 crises per year in 1970-1979 and 3 crises per year in 1995-1999. ${ }^{15}$ A similar pattern was revealed for the different regions.

\subsection{How are the predictions generated?}

A third set of issues pertains to the statistical methods used to generate the prediction of future crises. ${ }^{16}$ Two approaches are often used: the signal extraction approach (also known as

\footnotetext{
${ }^{14}$ The 20 countries are: Argentina, Bolivia, Brazil, Chile, Colombia, Denmark, Finland, Indonesia, Israel, Malaysia, Mexico, Norway, Peru, Philippines, Spain, Sweden, Thailand, Turkey, Uruguay, and Venezuela.

${ }^{15}$ Table 3 reports the actual KLR dates (column 1) and those I obtain replicating their study (column 2). KLR report 72 currency crises whereas I find 70 crises. There is no obvious pattern or explanation as to why my results do not match KLR. For some countries the same crises are identified, but for other countries different dating schemes emerge. I address some of these discrepancies in subsequent sections.

${ }^{16}$ Three different approaches have been used in the literature. Sachs, Tornell, and Velasco (1996), Tornell (1998), and Glick and Rose (1999) analyze the incidence of currency crises across groups of countries at a point in time, but not over time. This cross-section approach may shed light on common factors that generated the crisis but it does not help predict future crises. The other two approaches both estimate probabilities using a panel data set (across time and across countries). One approach uses a non-parametric technique of signal extraction (Kaminsky
} 
the indicators approach) and the regression and/or probit analysis approach. The former is based on monitoring a large set of indicators and evaluating whether the behavior of those variables differs around the crisis episode; while the latter uses more classical estimation techniques.

\section{Signal Extraction Method}

This section describes the indicators or signal-extraction method used by KLR. In general, the KLR approach is univariate, in that each variable is analyzed separately. This approach involves monitoring these variables, country by country, and identifying when a variable deviates from its "normal" level beyond a certain "threshold" value. For these extreme values a variable is said to issue a warning signal about a possible currency crisis. A "good" signal is one that is followed by a crisis within a signaling horizon or crisis window of so many months. When a variable issues a signal and a crisis does not follow within the crisis window, it is considered a "bad" signal or noise. KLR calculate the optimal threshold to be one that minimizes the noise-to-signal ratio, which is the ratio of bad signals to good signals.

Let $X$ be defined as an indicator variable. $X$ is said to "signal" a crisis in period $t$ if in that period the indicator crosses the critical threshold, Xbar. The signaling state is characterized by

$$
\left(S_{t}=1\right) \text { if }\left(\left|X_{t}\right|>|X b a r|\right)
$$

and Reinhart (1999) and Kaminsky, Lizondo and Reinhart (1998), while the other approach employs a probit regression (Frankel and Rose (1996), Berg and Pattillo (1998) and Kamin and Babson (1999)). The explanatory variables can be the same in both of these approaches. 
If $X$ does not exceed this threshold, $X b a r$, then there is no signal.

$$
\left(S_{t}=0\right) \text { if }\left(\left|X_{t}\right| \leq \mid \text { Xbar } \mid\right)
$$

Note that for some of the variables a decline in the indicator below some value indicates an increase in the probability of a crisis, while for other variables the rise above the threshold value indicates an increase in the probability of a crisis. Thus, the conditions in equations 3 and 4 are expressed in terms of the absolute values of their variables and their threshold levels.

\section{Thresholds and Performance of Indicators}

This signal-extraction method requires defining a signaling horizon, a threshold level, and then classifying the signals. The signaling horizon or crisis window is the period within which the indicator would be expected to have an ability for anticipating crises. KLR somewhat arbitrarily define this period as 24 months, which is consistent with other windows applied by other investigators, and is fixed for all indicators. The threshold level is defined so as to maximize the signaling performance of each indicator.

The outcome for an indicator can be considered in terms of a two by two matrix, shown in Table 4. For each variable there are four possible categories. A variable can issue a signal (row 1), indicating it is above (or below) the threshold, or it fails to issue a signal (row 2). A variable that issues a signal and a crisis follows within 24 months is considered a good signal (cell A). A variable that issues a signal and a crisis does not follow is considered noise or a "bad" signal (cell B). A variable that does not issue a signal and a crisis follows is a "missed" signal (cell C) and an indicator variable that does not issue a signal and no crisis follows is a "good silent" signal (cell D). 
For any variable and any given threshold level, the monthly signals issued by that variable can be placed into cells A, B, C, or D. The key to the signal extraction approach is to choose the threshold level so as to strike a balance between the risks of having many bad signals and the risk of missing many crises. The thresholds are calculated to minimize the noise-tosignal ratio. In terms of the matrix this implies minimizing the ratio: $[\mathrm{B} /(\mathrm{B}+\mathrm{D})] /[\mathrm{A} /(\mathrm{A}+\mathrm{C})] .{ }^{17}$ To obtain the "optimal" threshold a grid search is performed: the noise-to-signal ratio is calculated for a range of potential threshold values and that value which minimizes the noise-tosignal ratio becomes the threshold chosen for that variable.

It should be noted that thresholds are defined relative to the percentile of the distribution of the indicator by country. For example, if the optimal threshold for reserves is the 10th percentile, then one determines the value of reserves at the 10th percentile of its distribution for each country. The actual value varies across countries, but the percentile is the same. ${ }^{18}$

The box below illustrates the country-specific threshold (critical) values for reserve loss and export growth for Korea, Mexico, and Thailand. Both of these variables are considered to

${ }^{17}$ The decision rule to minimize the noise-to-signal ratio can also be put in the context of more standard statistical testing, using type I and type II errors. Let the null hypothesis $\left(\mathrm{H}_{0}\right)$ be equal to when a crisis occurs and the alternative hypothesis $\left(\mathrm{H}_{\mathrm{A}}\right)$ be when no crisis occurs. From Table $4, \mathrm{H}_{0}$ is equal to $\mathrm{A}+\mathrm{C}$ and $\mathrm{H}_{\mathrm{A}}$ is equal $\mathrm{B}+\mathrm{D}$. The size of a type $\mathrm{I}$ error is defined as the probability of rejecting $\mathrm{H}_{0}$ given that $\mathrm{H}_{0}$ is true $\left[\mathrm{P}\left(\right.\right.$ reject $\mathrm{H}_{0} / \mathrm{H}_{0}$ is true $\left.)\right]$. The type I error is then defined as $\mathrm{C} /(\mathrm{A}+\mathrm{C})$. If a country experiences only one crisis and the crisis window was 24 , then the type I error would be equal to the number of times an indicator did not signal as a ratio of 24. Similarly, the size of a type II error is the probability of not rejecting $\mathrm{H}_{0}$ when $\mathrm{H}_{0}$ is false [P(not reject $\mathrm{H}_{0} / \mathrm{H}_{0}$ is false)]. This is called a false signal and is equal to $\mathrm{B} /(\mathrm{B}+\mathrm{D})$. The selection of the appropriate threshold is difficult. One does not want to select too wide a threshold, including behavior that is close to normal or too narrow. The noise-to-signal ratio is defined to be the minimum of the ratio of type II errors to one minus the size of type I errors, which is expressed as $[\mathrm{B} /(\mathrm{B}+\mathrm{D})] /[1-\mathrm{C} /(\mathrm{A}+\mathrm{C})]$.

\footnotetext{
${ }^{18}$ To do this one calculates the empirical distribution for each country and from this one determines the value of Xbar.
} 
issue a signal if their values fall in the bottom 10 percent of their distribution for any particular country. However, because the distribution of these variables differs from country to country, so, too, do their threshold levels. A 5 percent annual decline in export growth would signal a crisis in Korea and Thailand. In Mexico, a decline of export growth greater than 6 1/2 percent would signal a crisis. Similarly, a 25 percent loss of foreign reserves would signal a crisis in Korea and Thailand, but not Mexico.

\begin{tabular}{|lcc|}
\hline & \multicolumn{2}{c|}{$\begin{array}{c}\text { Example of country-specific thresholds } \\
\text { Country }\end{array}$} \\
Critical Value for Export Growth & Critical Value for Reserve Loss \\
Korea & -0.8 & 22.2 \\
Mexico & -6.5 & 49.5 \\
Thailand & -4.5 & 9.2 \\
\hline
\end{tabular}

Other information besides the noise-to-signal ratio, can be derived from the matrix reported in Table 4. One can see that the "perfect" indicator is one in which $\mathrm{B}=0$, the noise-tosignal ratio would be zero. A "bad" indicator is one in which $\mathrm{A}=0$, then the noise-to-signal ratio is infinity. The results, usually, fall somewhere in between these two extreme cases. ${ }^{19}$ Other metrics that can be derived from Table 4 include the number of good signals issued as a percentage of total number of months a good signal could have been issued $[\mathrm{A} /(\mathrm{A}+\mathrm{C})]$, and the conditional probability that a crisis signals $[\mathrm{A} /(\mathrm{A}+\mathrm{B})]$.

In the following two sections indicators are assessed individually on the basis of two

${ }^{19}$ Note that although one might define a perfect indicator as one in which the variable signals every month prior to the crisis this typically would not be achieved. For example, the KLR sample spans twenty-five years or roughly 300 months. If the country in question had four crises, this would imply that $\mathrm{A}+\mathrm{C}$ equals 96 observations. Note that if the optimal threshold is the 10 th percentile and the sample size is 300 , then the largest value cell A can take on would be 30 . 
criteria: the noise-to-signal ratio, which is the ratio of bad signals to good, and the share of crises called correctly, or, more precisely, the fraction of crises in which the indicator signals at least once within the crisis window. Indicators can easily be ranked as top performers based on one criterion, but be ranked poorly based on the other. The difference in performance stems from how these two criteria weight the signals. Both criteria positively value correctly predicted crises, but the noise-to-signal ratio penalizes false alarms, that is, false positives, whereas the share of crises predicted correctly penalizes missed signals, that is, false negatives.

In subsequent sections, I use these methods to develop and provide evidence on the relative merits of a broad range of indicators.

\section{Implementation of the KLR Model}

This section discusses my attempt to reproduce the KLR bivariate results.

\subsection{Replication of KLR}

Table 5 presents information on the performance of individual indicators. ${ }^{20}$ Two sets of results are reported: my results (left-hand side) and the original KLR results (right-hand side). ${ }^{21}$ Column 1 shows the number of crises for which data on the indicator are available. Seventy crises are identified in my replication; KLR identified 72 crises. The data on some indicators either are not available or are missing in parts of the sample. For example, in the replication sample, data for six indicators (reserves, exports, real exchange rate, M2 multiplier, M2/reserves, and imports) existed for all 70 crises. In the original sample there were only three indicator

\footnotetext{
${ }^{20} \mathrm{~A}$ detailed table showing the results by a crisis-by-crisis, indicator-by-indicator basis is available from the author. Appendix Table A contains this information for the enlarged sample, hence for brevity it was omitted for the replicated sample.

${ }^{21}$ Column 1 of Table 3 gives the actual KLR crisis dates and column 2 of Table 3 reports my dates for the same time horizon.
} 
variables for which data existed for all 72 crises (reserves, exports, and the real exchange rate). In both samples the ratio of lending to deposit interest rates had the least number of crises to be used in the analysis, 36 crises for the replication sample and only 33 for the original sample.

Column 2 displays the size of the critical region where the noise-to-signal ratio is at a minimum, which is determined using a grid search over the range 0.1 to 0.2 . For a large majority of the variables the critical value is at the minimum value of 10 percent. This translates into examining extreme values at the tail of the distribution. For two variables in my sample, the lending-to-deposit ratio and stock prices, the critical value is at the maximum of twenty percent, which entails using a larger part of the sample.

The third column in Table 5 reports the noise-to-signal ratio, calculated as the ratio of false signals as a portion of the months in which there is no crisis $[\mathrm{B} /(\mathrm{B}+\mathrm{D})]$ relative to the good signals which is the proportion of months in which there was a crisis $[\mathrm{A} /(\mathrm{A}+\mathrm{C})]$. The best indicator based on the lowest noise-to-signal ratio is the real exchange rate. This result is consistent across both sets of results. Ratios that are equal to or greater than one imply that the indicator is not very good at signaling a crisis. KLR find that three indicators (commercial bank deposits, lending/deposit rate ratio, and imports) are not useful indicators. These three indicators in my sample, as well as the real interest rate differential, yield noise-to-signal ratios above one.

Column 4 reports the share of crises correctly called. For my sample, only 7 of the 14 indicators signaled at least once within the crisis window. By contrast, in the original KLR sample 13 of the 14 indicators signaled at least once within the crisis window for at least half of the crises. The best indicator based on this criteria differ between the two results. The export indicator is the "best" performer in my sample, while the real interest rate is the best performer in 
the KLR sample

The final column in the table contains the conditional probability of the crisis, or the probability that a crisis will occur given that the indicator is signaling that it will and is calculated as $\mathrm{A} /(\mathrm{A}+\mathrm{B})$. Like the noise-to-signal ratio, the conditional probability indicates the performance of the variable - in this case the higher the conditional probability the better the indicator. For example the conditional probability is 59 percent for the real exchange rate, but only 8 percent for the ratio of lending to deposit interest rates.

Overall, the results reported in Table 5 are similar to those presented in KLR. We both find that the top three indicators are: the real exchange rate, exports, and the ratio of M2 to foreign exchange reserves. However, there are some differences, mainly in the ranking of the performance of the indicator. There may be several reasons for the differences in the results. First, the raw data and the data transformations differ. Despite the fact that both data sets are derived from the same source, the International Monetary Funds IF Statistics, the data sets were created nearly two years apart and revisions to individual time series are quite common.

Moreover, two indicators require considerable data transformations, the deviation of the real exchange rate from the trend and the excess demand for money, and despite attempts to replicate the original transformations it is clear that I was not able to do so.

Second, it is not clear how KLR accounted for missing data within the crisis window. In my treatment, I attempted to correct the total number of observations and the elements in each cell in Table 4 for missing values. In addition, I attempted to take account of signals in overlapping crises windows. Finally, it should be noted that BP also had trouble replicating the KLR results. 


\section{Extensions and Modifications to the KLR Study}

In this section I expand the KLR study by adding countries and indicator variables. In particular, I add eight countries to the original twenty countries (Korea, Portugal, South Africa, Greece, India, Pakistan, Sri Lanka and Singapore) and I consider seven additional indicator variables (U.S. output, G-7 output, U.S. interest rates, oil prices, the level of M2/foreign exchange reserves, the change in short-term debt/foreign exchange reserves, and the level of short-term debt/foreign exchange reserves). ${ }^{22}$

\subsection{The Benchmark Model: In-Sample Results}

Table 6 provides summary information on the performance of the individual indicators, and is similar to Table $5 .{ }^{23}$ The results are computed for the expanded sample of countries over the horizon January 1970 to April 1995. Note that the last eight months in 1995 are dropped from the sample to provide a large enough window to evaluate the predictive capabilities of the model for the 1997 - 1999 crises.

Column 1 gives the number of crises per indicator. With an additional eight countries the number of crises identified increases to 91 from 70 . As before the number of crises per variable

\footnotetext{
${ }^{22}$ More specific details about the data can be found in the data appendix. Briefly, the two income variables are measured as the annual growth in US and G-7 countries' income. The change in the U.S. interest rate is the 12month change in the U.S. 3- month treasury bill rate, while oil price changes are 12-month percentage change in world oil prices. In section 4, I use the 12-month percentage change in M2/reserves: in this section I also include the level of the ratio of M2/reserves. Finally, I introduce two more indicator variables, the level and the 12-month percentage change in the ratio of short-term debt (BIS) to foreign exchange reserves.

${ }^{23}$ For a detailed analysis see appendix Table A which shows the results on a crisis-by-crisis and indicatorby-indicator basis. Each column gives the results for a particular variable. It contains information on the number of missing values and the number of times there was a signal during the crisis window. In the case of reserves, two crisis had all 24 observations missing, hence there are only 89 crises in the reserve calculation. For each indicator variable there is a set of summary statistics reported including, percentage of crises called, noise-to-signal ratio, probability of a crisis, size of the critical region, number of countries and number of crises.
} 
analyzed varies, ranging from 12 to 91 crises. $^{24}$ Column 2 reports the number of countries that have data for each variable. For many indicators, there are data for all 28 countries. However, for some indicators several countries did not have data.

Column 3 displays the size of the critical region, where the noise-to-signal ratio is at a minimum, which is determined using a grid search over the range 0.1 to 0.2 . For more than half the variables the critical region is calculated to fall at the 10 percent level, the smallest critical region. Column 4 reports the noise-to-signal ratio for each of the variables, ranging from 0.26 to 2.7. The noise-to-signal ratio is less than one for all the new variables and there are only modest differences between the earlier results due mainly to changes in threshold level. There are two exceptions: imports and the real interest differential, where the noise-to-signal ratio falls for both variables. I discuss the performance (ranking) of the indicators below.

The conditional probability of a crisis, given in column 5, varies across variable, ranging from one-half to less than one tenth. These probabilities correspond to the performance of the noise-to-signal ratios and are much in line with those reported earlier. Finally, column 6 gives the share of crises for which the indicators issued at least one signal during the twenty-four months prior to the crisis. With the larger sample, I find that more than half of the variables issue at least one signal in the crisis window prior to the crisis. The results from the enlarged sample are approximately the same as those in the replication sample.

\section{Performance of the Individual Indicators}

The performance of each indicator is assessed on the basis of two criteria: the signal-to-

\footnotetext{
${ }^{24}$ The number of crises that we have for the indicator variable short-term debt/reserve ratio is quite limited as we have no data prior to 1986 and the data are available for only 9 of the 28 countries.
} 
noise ratio (the inverse of the noise-to-signal ratio - column 4 in Table 6), which is the ratio of good signals to noise, and the share of crises called correctly (column 6 in Table 6) or more precisely, the fraction of crises in which the indicator signals at least once within the crisis window. The upper panel of Figure 3 ranks the indicators based on the signal-to-noise criterion, computed for the 28 countries in the benchmark model. The real exchange rate, measured as the deviation from its trend, is ranked the top performer; its signal-to-noise ratio is about eight times that of the worst-performing indicator. The next best performer is the 12-month percent change in the ratio of short-term debt to reserves.

The lower panel of the exhibit presents the performance of the indicators based on the share of crises called correctly, ordered by the signal-to-noise rankings in order to facilitate comparison with the upper panel. Using this criterion, the best indicator is the 12-month percent change in the ratio of short-term debt to reserves. It issued at least one signal prior to 11 of the 12 crises for which there are data for this indicator. The next best indicator is export growth, shown in bold halfway down the panel, which predicted 72 percent of 89 crises. The real exchange rate is ranked 15 th using this criterion even though it was the best indicator based on the signal-to-noise criterion. This change in ranking reflects the fact that prior to several crises, the real exchange rate was overvalued for extended periods, yielding a large number of good signals and hence a high signal-to-noise ratio. However, for many crises the real exchange rate did not provide any signal at all, yielding a low ranking in terms of correct calls.

Several conclusions emerge from examining the performance of this expanded early warning system model. The additional eight countries and slight adjustment to in-sample size resulted in modest changes. The seven additional indicator variables all had noise-to-signal 
ratios lower than 1 , suggesting that they are informative. The expanded country coverage had no impact on the dating of crises as this is done on a country-by-country basis, but did affect the selection of the optimal threshold, as one minimizes the aggregate noise-to-signal ratio for all countries. Consequently, the threshold percentile for some variables changed and some results were modified slightly.

\subsection{The Benchmark Model: Out-of-Sample Results}

In the following discussion I examine combining information from the benchmark model on the various indicators and estimate the probability of a crisis on the signals simultaneously.

\section{Construction of Composite Crisis Indicators}

In principle, the greater the number of indicators signaling a future crisis, the higher the probability that such a crisis will actually occur. Therefore, one straightforward way of capturing the vulnerability of the economy to a crisis is to keep a scorecard of the number of signals being issued. As Kaminsky (1998) has described, there are a number of different ways one can combine individual indicators to create a composite indicator of vulnerability. In what follows I consider two of these methods.

The first composite index is based on summing the number of indicators signaling at any point in time that there is a crisis. The first composite indicator $\left(I_{t}^{l}\right)$ is defined as follows:

$$
I_{t}^{1}=\Sigma S_{t}^{j}
$$

where $S_{t}$ is equal to one if variable $j$ crosses the threshold in period $t$ and zero otherwise. The composite index derived from equation (5) simply tallies the number of signals. So, if four 
indicators were above (below) their optimal threshold, each of the corresponding $S_{\mathrm{t}}$ would be one and the index $I_{t}$ would equal four.

While this method provides some aggregate information, it does not fully utilize the information gained from the previous bivariate analysis. In contrast, the second index weights more heavily the signals issued by indicators shown to have more reliable forecasting performance. The weights it uses are the inverses of the noise-to-signal ratios of the univariate indicators. Indicators with low noise-to-signal ratios receive a larger weight relative to those variables with a high noise-to-signal ratio. The second composite indicator is defined as follows:

$$
I_{t}^{2}=\Sigma S_{t}^{j} / \omega^{j}
$$

where $\omega^{\mathrm{j}}$ is the noise-to-signal ratio of variable $j$.

Tables 7 and 8 report the evolution of these composite indicators for some Latin American and Asian countries, respectively. ${ }^{25}$ The composite indicators reported in the tables cover the time period May 1995 to December 1999. Their values may be interpreted as out-ofsample predictions, insofar as the threshold levels for the individual indicators and the weights used to aggregate them into composite indicators were estimated using data from January 1970 to April 1995. For each country, I report the number of indicators available (column 1), the total number of good signals (column 2 - composite indicator one) and the noise-to-signal weighted index (column 3 - composite indicator two). The maximum value for composite indicator one is

${ }^{25}$ The composite indicators I report are constructed using only 16 of the 21 indicator variables. I use this subset of the indicators because some of the indicators are not informative and others are simply substitutes for one another. 
16, which occurs when all signals are flashing. The maximum value for composite indicator two is 27.1 , the sum of the signal-to-noise ratio when all signals are flashing.

Table 7 gives the results for three Latin American countries (Argentina, Brazil, and Mexico). For Brazil, every month from December 1995 to August 1999 at least two indicators and often more were signaling, particularly in the runup to January 1999 when the exchange rate peg was abandoned. The behavior of the composite indicators differs from Mexico over much of this time period. From May 1995 to December 1995, the indicators showed the Mexican economy remained vulnerable after its 1994 crisis. However, tranquility returned, no variable signaled in Mexico in 1996, and the composite indicators were zero. In contrast, Argentina showed signs of vulnerability, starting in June 1998.

Table 8 contains the same predictive information for five Asian countries (Indonesia, Korea, Malaysia, Philippines, and Thailand). The results for these countries are more striking than those for Latin America. For Korea, Malaysia, the Philippines, and Thailand a number of variables showed signs that the economies were becoming more vulnerable prior to the summer of 1997. In Thailand, for example, the number of indicators signaling increased to 6 in May and June 1997, just two months prior to the devaluation of the baht. The Thai weighted composite index for those months was close to 10 . In contrast, the model does poorly in attempting to capture the fragility of Indonesia as few indicators issued signals prior to the crisis.

\section{Probabilities of a Currency Crisis}

While the composite indicators described above may be informative, it is difficult to infer from their values the likelihood that a country will experience a crisis. However, it is possible to calculate for each value of the composite index an associated probability of future crisis. For the 
weighted composite index I calculate these probabilities using the following formula:

$$
P\left(C_{t, t+h} \mid I_{i}^{2}<I_{t}^{2}<I_{j}^{2}\right)=\frac{\sum \text { Months with } I_{i}^{2}<I_{t}^{2}<I_{j}^{2} \text { given a crisis occurs within } h \text { months }}{\text { Months with } I_{i}^{2}<I_{t}^{2}<I_{j}^{2}}
$$

where $P$ denotes probability, $C_{t, t+h}$ is the occurrence of a crisis in the interval $[t, t+h]$, h is the crisis window (24 months), $I^{2}$ is the weighted index and the subscripts $i$ and $j$ denote upper and lower intervals for the composite index indicator. $P\left(C_{t, t+h} / I_{i}^{2}<I_{t}^{2}<I_{j}^{2}\right)$ denotes the probability that a crisis will occur within $h$ months at time $t$, given that the composite indicator $I_{t}^{2}$ falls within the range $I_{i}^{2}$ and $I_{j}^{2}$.

Table 9 reports the conditional probabilities of a currency crisis that are associated with different values of the weighted composite index. The odds of a currency crisis increase as the signs of vulnerability of the economy increase, especially in the higher categories. Given this method, the highest probability of a crisis for all the countries is 50 percent. This result is quite common in the literature: typically researchers find the estimated probabilities are quite low. One explanation for this finding is that frequently indicators are signaling and no crisis follows. Another explanation is that the period following the crisis is included in the tranquil period, but it takes time for macroeconomic adjustment and the economy to return to 'normal'. ${ }^{26}$

We consider two ways of analyzing these probabilities. First, we examine the probabilities across countries at two points in time (a cross-country comparison). Second, we report the probabilities over time for a subset of these countries (intertemporal comparison).

\footnotetext{
${ }^{26}$ Therefore, one could recalculate the probabilities adjusting for the aftermath window. This is clearly an interesting idea, but if implemented it would require adjusting the other statistics such as the noise-to-signal ratios. These adjustments are beyond the scope of the current paper.
} 
Figure 4 presents out-of-sample crisis probabilities at two points in time-December 1996 and July 1999-for 21 countries in the sample. The countries are ranked in descending order based on their crisis probabilities in 1996. The countries associated with the highest probabilities in December 1996 were: Pakistan, South Africa, Brazil and Colombia. These countries were followed closely by Malaysia, Philippines, Turkey and India. Most of these countries experienced full-blown crises in 1997/8, or experienced persistent macroeconomic and financial difficulties in recent years, only India has not experienced financial disruption of varying degrees. On the other hand, estimated probabilities were considerably lower for two other major crisis countries: Indonesia and Korea.

Taking a look at these same 21 countries in July 1999, we see a very different picture. The probabilities for most countries have decreased, consistent with the more benign outlook for emerging market countries. Only for Venezuela, Indonesia, Singapore, and Argentina are increases in crisis probabilities registered.

Table 10 takes a closer look at these probabilities and the signals that are flashing for the 21 countries for December 1996. The first column gives the country name and the second column reports the crisis aggregate probability. The columns 6 - 20 indicate which indicator is signaling a crisis. Take, for example, Brazil. The aggregate probability of a crisis was 33 percent and three variables (stock prices, bank deposits and excess money demand) were contributing to the elevated probability.

Figure 5 presents another look at this same data, plotting the crisis probabilities for the 
eight countries reported in Table 7 and 8 for the period January 1990 to July $1999 .^{27}$ A noticeable feature of these graphs is that the probabilities are quite jagged. In general the figures highlight some of our earlier findings. The probabilities are quite low for Argentina throughout the period, partially because it did not experience a crisis. Note that immediately following the Mexican crisis, and immediately prior to the Brazilian crisis, Argentina's probabilities are elevated. For Brazil, the probability of a crisis is elevated in 1997 and increases immediately before January 1999. Turning to the figures on Asia we find that for all of the countries, the probabilities are higher, on average, during the signaling window preceding the start of the financial crisis in 1997 than their average for the decade.

In summary, I find that the composite index was elevated in many countries prior to the 1997 crisis, especially those in Asia. It was also elevated prior to Mexico's 1994 crisis and Brazil's 1999 crisis. Nonetheless, the composite index can hardly be relied upon as an exclusive measure of vulnerability. The index has two main drawbacks: it is highly variable and it is hard to interpret the probabilities.

\section{Case Study: An Evaluation of Indicators Approach for Mexico}

To provide a sense of how this approach can be implemented in practice, this section examines the usefulness of the indicators approach for a single country and uses Mexico as an example. In addition, a crude alternative method of generating thresholds and hence calculating signals is considered for comparison.

\footnotetext{
${ }^{27}$ The data from January 1990 to April 1995 should be treated as in-sample probabilities and the data from May 1995 to August 1999 should be treated as out-of-sample probabilities.
} 


\section{A Closer Look at the Indicators}

Figure 6 presents data on Mexican indicators. The upper portion of the Figure 6 contains six panels, displaying the evolution of selected individual indicators-the solid lines-with their estimated thresholds as the dashed lines. The shaded period is January 1993 to December 1994, representing the 24-month signaling window preceding the peso crisis. The upper left panel shows that the real exchange rate variable was above-although only slightly-the upper threshold nine times in the crisis window, signaling vulnerability. The panels for reserves, the M2-toreserves ratio, and the short-term-debt-to-reserves ratio show that these variables signaled only once-in December 1994, just as the crisis began to unfold. The remaining two indicators are the equity index and excess money balances. Each of these variables crosses the threshold several times during the crisis window.

Table 11 reports on the performance of all the Mexican indicators. Each row has six columns and contains information about an individual indicator. The first four columns show the number of times a signal was issued in the 24-month window preceding the indicated crisis. The last two columns present aggregate information, namely, the threshold level and the country's aggregate noise-to-signal ratio. Take for example the row marked reserves, measured as 12month percentage change. According to column 5, a decline of more than 50-percent (per annum) in reserves is the 'optimal' threshold, such that larger declines in reserves signal a crisis. Given this information we see that reserves registered 'large' year-over-year losses in 8 months of the 24-month window prior to the December 1982 crisis and once in the 24-month window prior to the December 1994 crisis. The overall performance of this indicator is given by the noise-to-signal ratio. For Mexico, the noise-to-signal ratio is 0.86 , which is higher than the 
multi-country average of 0.53 .

Based on the noise-to-signal criteria, eight of the twenty variables (reserves, real exchange rate, equity prices, imports, excess M1 real balances, U.S. growth, level of M2/reserves, and G-7 growth) appear useful for Mexico. The noise-to-signal ratio is zero for the real exchange rate, because all 31 extreme observations occurred during one of the four crisis windows. The remaining indicators did not perform very well for Mexico or were not readily available.

The lower panel in Figure 6 displays the resulting 24-month-ahead probabilities of a crisis for Mexico for the entire period, with the period after May 1995 containing out-of-sample probabilities. A striking feature of this figure is that the calculated probabilities (the solid line) are quite jagged and the probabilities are not always higher during the 24-month windows prior to currency crises (the shaded areas) than during the non-crisis periods. However, the dashed lines, the average probabilities of a crisis inside and outside the crisis windows, show that the probability of a crisis is indeed elevated inside the crisis windows relative to outside the crisis windows. This result suggests that the model provides some useful information about Mexico's vulnerability to a crisis.

\section{An Alternative Method}

The information obtained from the above exercise may be useful for a country analyst, but it requires a fair bit of work as the threshold information is derived from pooling information for all the countries. Instead I consider a similar, but simpler approach, that requires only country specific information. The method defines the threshold to be the mean of the indicator 
plus (or minus) 1.5 of its standard deviations. ${ }^{28}$ I chose 1.5 standard deviation because it yielded a reasonable number of observations, but not too many observations. It should be noted that this method does have a drawback, namely, the thresholds are sample dependent. It is conceivable to improve this single country method, but it is beyond the scope of this current paper.

For this exercise, I consider a subset of the indicators using twelve of the original indicator variables, which are transformed in the same way. Table 12 reports the number of "signals," the threshold value, and the number of observations contained in each of the 24-month crisis windows Five of the twelve indicators (reserves, exports, the real exchange rate, M2/reserves, and imports) perform reasonably well, each issuing at least one signal prior to at least one crisis. The other indicators perform poorly, partly because the total number of signals (good + bad) is quite small. Figure 7 plots the results, drawing the indicator variable and the alternative threshold level. Many of these threshold levels are close to those reported using the pooled information.

Overall, the results of the alternative method together with the individual country results from the EWS might provide a country analyst with some useful information. It is not clear from this analysis whether this information yields more accurate and earlier predictions of vulnerability than other methods might.

\section{Sensitivity Analysis}

One of the problems with the signal extraction approach is that one cannot use standard statistical tests to evaluate the robustness of the results reported in section 4 and 5 . In this section I study the robustness of the results. In particular, I analyze whether the benchmark

\footnotetext{
${ }^{28}$ Steve Kamin suggested this type of measure.
} 
model is robust to regional differences and to changes in crisis definition.

\subsection{Regional Differences}

To analyze how robust these results are across regions, I reconsider the performance of the indicators by examining two regional groups: Latin America (Argentina, Bolivia, Brazil, Colombia, Mexico, Peru, Uruguay, Venezuela, and Chile) and Asia (Indonesia, Korea, Malaysia, Philippines, Thailand, India, Pakistan, Sri Lanka, and Singapore). I conduct this comparison using the expanded data set for the sample period, January 1970 to May 1995.

Table 13 gives a summary of the results for the two regions. For each region the maximum number of countries analyzed at one time is nine and the maximum number of crises is 28 for Latin America and 25 for Asia. For both regions, the top indicator, based on noise-tosignal ratio, is the deviation from trend of the real exchange rate. The other top performers are those found in the benchmark model with slightly different rankings: level of M2/reserves, change in short-term debt/reserves, level of short-term debt/reserves, change in reserves, and change in M2/reserves

Differences across the regions are also evident. The performance of the indicators vary between the regions based on the share of crises called. For Latin America the top 3 indicators using this performance measure are: exports (93 percent), changes in short-term debt to reserves (88 percent) and changes in reserves (79 percent). For Asia the top performers are changes in short-term debt to reserves (100 percent), changes in M2 multiplier (83 percent), and the change in the ratio of domestic credit to GDP (63 percent). Another notable difference between the regions, besides differences in the ranking, is that the general performance of the indicators seems better for Latin America than for Asia, as noise-to-signal ratios are on the whole lower and 
the share of crises called is higher.

\subsection{The Crisis Index}

The method used to identify crises has several drawbacks. One of these drawbacks is that the method is sample dependent. When a large change occurs - such as a crisis which leads to large movements in exchange rates or foreign reserves - the sample mean and the sample variance can change substantially, leading to changes in the dating scheme. Table 3 reports on different dating schemes, highlighting some of the potential problems.

The first column of Table 3 reports the original KLR dates. Column 2 reports the crisis dates I have identified using data from January 1970 to April 1995, while column 3 reports the dating scheme for the sample January 1970 to December 1999. For most countries the dates of crises are unchanged when the sample is increased. However, for five Asian countries in particular (Korea, Malaysia, Thailand, Pakistan, and Singapore), the dating of crises changes when the sample in expanded. For example, it was reported that Malaysia in the earlier sample had five crises prior to April 1995, while in column 3 (larger sample), only one crisis in 1997 is identified. This difference stems from the large changes in the exchange rate and foreign reserves that occurred after the 1997 crisis. This big change in crisis dating seems to arise only after a big crisis, which seems to be a drawback for a method that is trying to predict crises.

To cope with this problem one needs to use a method that is not sample dependent. In this paper, I consider using the Frankel-Rose method, which arbitrarily specifies a threshold. FR define a crisis as a nominal depreciation of the currency of at least 25 percent and that this depreciation exceeds the previous year's change by a margin of at least 10 percent. Columns 4 and 5 of Table 3 give the dates of the crises for the two different time periods. All of the crises 
identified in column 4 are identified again when the sample is expanded as shown in column 5.

A comparison between the two dating methods -- KLR (column 3) and FR (column 5) -shows that there are many differences in the dating of crises between the two methods. The FR method does not pick up many crises in the EMS countries (e.g., Denmark, Finland, and Sweden), while it tends to identify more crises for many of the Latin American countries such as Brazil and Peru. For a few countries, both methods tend to pick out the same dates (see for example Indonesia and Colombia).

\subsection{Recalculate results using alternative dating scheme}

Table 14 reports the results of the crisis-prediction model using the FR dating scheme for the sample January 1970 - December 1995 for the expanded list of countries. As shown in Table 3, five countries in this sample are not associated with crises prior to December 1995 and hence are effectively dropped from the analysis; consequently, only 23 countries are used in the evaluation of the performance of the indicators. Once again the top indicator using the noise-tosignal criterion, is the deviation of the real exchange rate from trend. Based on this same performance measure, the other top performers are: equity price changes, export growth, and changes in the ratio of short-term debt to reserves. As we have reported before, the ranking of the indicators is different using the share of crises correctly called. Based on this measure the top indicators are: changes in short-term debt to reserves, exports and equity prices. Overall, the performance of the indicators seem invariant to the dating methods.

\section{Conclusions}

This paper develops an early warning system and identifies which variables tend to indicate that a country might be vulnerable to a financial crisis. In particular, it develops a 
benchmark model. This model is evaluated based on the in-sample performance of the indicators and also the out-of-sample probabilities of a crisis. The model is shown to be helpful in identifying vulnerabilities. This assessment of vulnerabilities can be applied to an individual country over time, as shown in the case study for Mexico, or across a group of countries at a particular point in time.

The performance of the early warning system is mixed. The model gives rise to many false alarms, largely because the sample contains mostly observations within non-crisis periods. Nevertheless, subjecting the benchmark model to several robustness tests, including examining regional differences and alternative dating schemes, I find some differences emerge across regions but that the performance of the indicators is reasonably robust. However, research into early warning systems is still in its initial stages and there remains scope for improving the models in several dimensions.

Going forward I hope to continue to explore improvements to the early warning system. One line of research includes analyzing the time series properties of the exchange rate market pressure variable and the indicator variables. The current design of the early warning system implicitly assumes that these variables are normally distributed and uses this assumption to study the behavior of outliers which are associated with crises. A detailed analysis of the statistical properties of the data would assist in the reformulation of the models.

In refining the early warning system, it might be useful to explore alternative statistical methods. For example, the IMF uses a similar system, but estimates the probability of a crisis using a probit model. This methodology as well as using an alternative regime switching model, which also includes as an explanatory variable the duration of the exchange rate regime, should 
be investigated. One always has to keep in mind that the accuracy of such a system is likely to be highly imperfect. The goal would be to improve the performance by addressing as many of the statistical shortcomings as possible.

While experimenting with and refining the early warning system, additional explanatory variables should be considered. An example of some of the additional variables are: the volatility of the exchange rate, the volatility of interest rates, changes in the inflation rate, and variables that capture contagion. The more volatile are inflation, interest rates, and exchange rates, the higher are the risks for financial institutions. An explanatory variable characterizing the financial and trade links between countries might also improve the performance of the model as the occurrence of financial crises in other countries could trigger a financial crisis domestically.

Several general conclusions emerge from this study: Currency crises by their nature are uncertain and hence are difficult to predict. Some variables provide early indications, but there are many false alarms. The early warning model helps to identify the countries that are most vulnerable to crisis, but the model does relatively poorly at predicting the exact timing of crises.

The current analysis provides insight into which variables should merit more scrutiny. In particular, I find that some of the more important indicators of vulnerability are: a marked appreciation of the real exchange rate (relative to trend), a high ratio of short-term debt to reserves, a high ratio of $\mathrm{M} 2$ to reserves, substantial losses of foreign exchange reserves, and sharply declining equity prices. Finally, it cannot be emphasized enough that these models, while useful as a diagnostic tool, must be complemented by more standard country surveillance and cannot substitute for such surveillance. 


\section{References:}

Berg, Andrew and Catherine Pattillo,1999a "Predicting currency crises: the indicators approach and an alternative," Journal of International Money and Finance, August, 18:4, 561 - 586.

Papers, June, 46:2, 107 - 138. , 1999b "Are currency crises predictable? A test, " IMF Staff

system approach," unpublished, Washington D.C., International Monetary Fund.

Eichengreen, Barry, Andrew Rose, and Charles Wyplosz, 1994, "Speculative attacks on pegged exchange rates: An empirical exploration with special reference to the European monetary system," NBER Working Paper No. 4898, Cambridge, National Bureau of Economic Research.

The antecedents and aftermath of speculative attacks," Economic Policy, October, 249 - 312. , (1995), "Exchange market mayhem: , 1996, "Contagious currency crises,"

NBER Working Paper No. 5681, Cambridge, National Bureau of Economic Research.

Frankel, Jeffrey and Andrew Rose, 1996, "Currency crashes in emerging markets: An empirical treatment," International Finance Discussion Paper No. 534, Board of Governors of the Federal Reserve System, January.

Girton, Lance and Don Roper, 1977, "A monetary model of exchange market pressure applied to postwar Canadian experience," American Economic Review, September, pp 537 - 548.

Glick, Reuven and Andrew Rose, 1999, "Contagion and trade: Why are currency crises regional?" Journal of International Money and Finance, August, 18:4, 603 - 618.

Goldstein, Morris, Graciela Kaminsky, and Carmen Reinhart, 1999, "Assessing financial vulnerability: An early warning system for emerging markets," unpublished manuscript, Washington, DC: Institute for International Economics.

Kamin, Steven, 1999, "The current international financial crisis: how much is new?" Journal of International Money and Finance, August, 18:4, 501 - 514.

Kamin, Steven and Oliver Babson, 1999, "The contribution of domestic and external factors to Latin American devaluation crises: An early warning systems approach," unpublished, Washington, D.C., Board of Governors of the Federal Reserve.

Kaminsky, Graciela, 1998, "Currency and banking crises: A composite leading indicator," 
unpublished, Washington, D.C., Board of Governors of the Federal Reserve System.

Kaminsky, Graciela, and Carmen Reinhart, 1999, "The twin crises: The causes of banking and balance of payments problems," American Economic Review, June, 89:3, 473 - 500.

Kaminsky, Graciela, Saul Lizondo and Carmen Reinhart, 1998, "Leading indicators of currency crises," International Monetary Fund Staff Papers, 45, 1-48.

Masson, Paul, Eduardo Borensztein, Andrew Berg, Gian Maria Milesi-Ferretti and Catherine Pattillo, 1999, "Anticipating balance of payments crises: The role of early warning systems," unpublished manuscript, Washington D.C., International Monetary Fund.

Sachs, Jeffrey D., Aaron Tornell, Andres Velasco, 1996, "Financial crises in emerging markets: The lessons from 1995," Brookings Papers on Economic Activities, pp 147 - 198.

Tornell, Aaron, 1998, "Common fundamentals in the tequila and Asian crises," Harvard University, unpublished. 


\section{Data Appendix}

Primary Data Source: International Financial Statistics (IFS). Other sources noted by indicator. Unless otherwise noted, we used a 12-month percent change measure for each variable.

\begin{tabular}{|c|c|}
\hline The Indicator & Source and Definition \\
\hline 1. Foreign Exchange Reserves & IFS line 1L.d \\
\hline 2. Exports & IFS line 70_d \\
\hline 3. Real Exchange Rates & $\begin{array}{l}\text { Nominal bilateral exchange rate - Line } 00 \mathrm{ae} \text {. The real exchange rate is the nominal } \\
\text { exchange rate ( } \mathrm{fx} / \$ \text { rate), adjusted for relative consumer prices. An appreciation of } \\
\text { the } \mathrm{fx} \text { is a decline in the real exchange rate. Indicator is measured as deviation from } \\
\text { trend. }\end{array}$ \\
\hline 4. Index of Equity Prices & IFS line 62 \\
\hline 5. Commercial Bank deposits & IFS line 24 plus line 25 [deflated by CPI] \\
\hline 6. Output Index & Industrial Production IFS line 66 \\
\hline 7. Excess real M1 balances & $\begin{array}{l}\text { Defined as M1 (IFS line 34) deflated by consumer prices (IFS line 64) less an } \\
\text { estimated demand for money. Demand for real money balances is estimated as a } \\
\text { function of real GDP (interpolated IFS line 99b.p), domestic consumer price } \\
\text { inflation, and time. }\end{array}$ \\
\hline 8. M2 Multiplier & The ratio of M2 (IFS lines 34 plus 35) relative to base money IFS line 14. \\
\hline 9. M2/Reserves & IFS lines 34 plus 35 relative to reserves IFS line 1L.d \\
\hline 10. Domestic Credit/GDP ratio & $\begin{array}{l}\text { Total Domestic credit IFS line } 32 \text { which was then divided by nominal GDP } \\
\text { (quarterly or annual GDP (IFS line 99B) interpolated to monthly). }\end{array}$ \\
\hline 11. Real Interest Rate & Deposit interest rate (IFS line 601) deflated by consumer price inflation (IFS line 64) \\
\hline 12. Real Interest Rate Differential & $\begin{array}{l}\text { The interest rate differential is constructed as the difference between real rates for the } \\
\text { domestic and foreign country, using real [lending] interest rates. Domestic rates are } \\
\text { compared with interest rates in the United States [Germany if domestic central bank } \\
\text { is in Europe.] }\end{array}$ \\
\hline 13. Lending to Deposit Ratio & Lending interest rate IFS line 60p divided by deposit interest rate IFS line 601 \\
\hline 14. Imports & IFS line 71_d \\
\hline 15. Foreign G-7 Growth & Weighted average of G-7 real GDP growth \\
\hline 16. US Interest Rate & IFS line 60c \\
\hline 17. World Oil Price & IFS line 00176aaz \\
\hline 18. Short-Term Debt/Reserves & $\begin{array}{l}\text { Short-term debt is from the BIS and is debt with maturity less than } 1 \text { year measured } \\
\text { semi-annually. Foreign exchange reserves is IFS line } 1 \text { d. }\end{array}$ \\
\hline
\end{tabular}




\begin{tabular}{|c|c|c|c|}
\hline \multirow[b]{2}{*}{ Category } & \multicolumn{3}{|c|}{$\begin{array}{c}\text { Table } 1 \\
\text { Interpretation of Leading Indicators }\end{array}$} \\
\hline & Indicator & Tail & Comments \\
\hline \multirow[t]{3}{*}{ Current Account } & deviation of the real exchange rate & lower & $\begin{array}{l}\text { Real exchange rate over-valuations ( -) are } \\
\text { linked to currency crisis }\end{array}$ \\
\hline & imports & upper & $\begin{array}{l}\text { Weak external sector is part of currency } \\
\text { crisis }\end{array}$ \\
\hline & exports & lower & $\begin{array}{l}\text { Weak external sector is part of currency } \\
\text { crisis }\end{array}$ \\
\hline \multirow[t]{4}{*}{ Capital Account } & foreign exchange reserves & lower & $\begin{array}{l}\text { Loss of foreign reserve characteristic of } \\
\text { currency crisis ala Krugman. }\end{array}$ \\
\hline & M2/foreign exchange reserves & upper & $\begin{array}{l}\text { Expansionary monetary policy and/or sharp } \\
\text { decline in reserves are associated with the } \\
\text { onset of a crisis }\end{array}$ \\
\hline & real interest rate differential & upper & $\begin{array}{l}\text { High world interest rates may lead to } \\
\text { reversal of capital flows }\end{array}$ \\
\hline & short-term debt/reserves & upper & $\begin{array}{l}\text { Increases in short term debt and/or sharp } \\
\text { declines in reserves are associated with crises }\end{array}$ \\
\hline \multirow[t]{2}{*}{ Real Sector } & industrial production & lower & Recessions often precede financial crises \\
\hline & equity indices & lower & $\begin{array}{l}\text { Burst of asset price bubbles often precede } \\
\text { financial crises }\end{array}$ \\
\hline \multirow[t]{6}{*}{ Domestic Financial } & M2 multiplier & upper & Rapid growth of credit \\
\hline & domestic credit/GDP & upper & $\begin{array}{l}\text { Credit expands prior to crisis and contracts } \\
\text { after. }\end{array}$ \\
\hline & domestic real interest rates & upper & $\begin{array}{l}\text { High real interest rates could signal a } \\
\text { liquidity crunch or have been increased to } \\
\text { fend off a speculative attack }\end{array}$ \\
\hline & excess real M1 balances & upper & $\begin{array}{l}\text { Loose monetary policy can lead to currency } \\
\text { crisis }\end{array}$ \\
\hline & commercial bank deposits & lower & Loss of deposits occur as crisis unfolds \\
\hline & lending/deposit interest rates & upper & $\begin{array}{l}\text { Lending rates tend to rise prior to crisis, } \\
\text { reflecting decline in loan quality }\end{array}$ \\
\hline \multirow[t]{4}{*}{ Global } & G-7 output & lower & Foreign recessions often precede crises \\
\hline & US output & lower & US recession often precedes crises \\
\hline & US interest rate & upper & $\begin{array}{l}\text { Rate increases often associated with capital } \\
\text { outflows }\end{array}$ \\
\hline & Oil prices & upper & High oil prices are associated with recessions \\
\hline
\end{tabular}




\section{Number of Identified Crises by Region: 1970-1999}

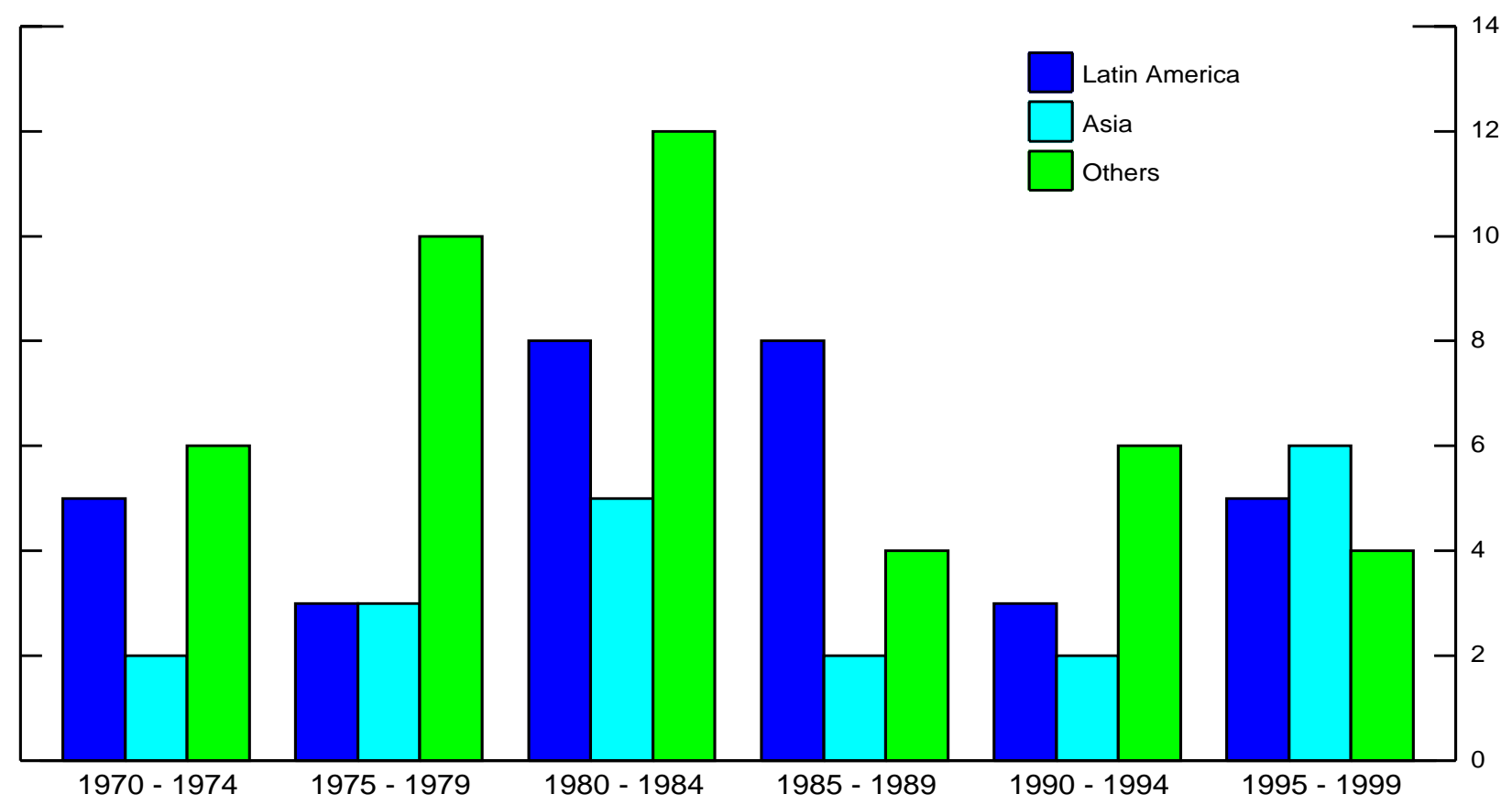

$\begin{array}{lcccc}\text { Years } & \text { Latin America } & \text { Asia } & \text { Other } & \text { Number of Crises } \\ 1970-1974 & 5 & 2 & 6 & 13 \\ 1975-1979 & 3 & 3 & 10 & 16 \\ 1980-1984 & 8 & 5 & 12 & 25 \\ 1985-1989 & 8 & 2 & 4 & 14 \\ 1990-1994 & 3 & 2 & 6 & 11 \\ 1995-1999 & 5 & 6 & 4\end{array}$

Note: The numbers reported in the table summarize the data for the expanded sample (28 countries) and the entire historical sample (1970-1999). See Table 3 for details on the dating of individual country crises.

Source: Author's calculation. 


\begin{tabular}{|c|c|c|c|c|c|}
\hline \multicolumn{6}{|c|}{$\begin{array}{c}\text { Table } 3 \\
\text { Crisis Dates }\end{array}$} \\
\hline \multirow[b]{2}{*}{ Country } & \multicolumn{3}{|c|}{ Exchange Rate Pressure Index } & \multicolumn{2}{|c|}{ Devaluation Episodes } \\
\hline & $\begin{array}{l}\text { Original KLR } \\
\text { Dates }\end{array}$ & $\begin{array}{c}\text { Replication of } \\
\text { KLR Crisis Date } \\
1970 \text { - } 1^{1995}{ }^{1}\end{array}$ & $\begin{array}{c}\text { Replication of } \\
\text { KLR Crisis Date } \\
1970 \text { - } 1999\end{array}$ & $\begin{array}{l}\text { Frankel - Rose } \\
\text { Method 1970 - } \\
1_{1995^{2}}\end{array}$ & $\begin{array}{c}\text { Frankel - Rose } \\
\text { Method 1970 - } \\
1999\end{array}$ \\
\hline \multirow[t]{7}{*}{ 1. Argentina } & Jun-70 & Mar-75 & Mar-75 & Mar-75 & Mar-75 \\
\hline & Jun-75 & Jul-82 & Jul-82 & Apr-81 & Apr-81 \\
\hline & Feb-81 & Apr-89 & Apr-89 & Jul-84 & Jul-84 \\
\hline & Jul-82 & Dec-89 & Dec-89 & May-87 & May-87 \\
\hline & Sep-86 & & & & \\
\hline & Apr-89 & & & & \\
\hline & Feb-90 & & & & \\
\hline \multirow[t]{3}{*}{ 2. Bolivia } & Nov-82 & Nov-82 & Nov-82 & Oct-72 & Oct-72 \\
\hline & Nov-83 & Nov-83 & Nov-83 & Feb-82 & Feb-82 \\
\hline & Sep-85 & Sep-85 & Sep-85 & & \\
\hline \multirow[t]{7}{*}{ 3. Brazil } & Feb-83 & & & Jun-76 & Jun-76 \\
\hline & Nov-86 & Sep-82 & Sep-82 & May-79 & May-79 \\
\hline & Jul-89 & Mar-90 & Mar-90 & Dec-81 & Dec-81 \\
\hline & Nov-90 & Nov-90 & Nov-90 & Feb-83 & Feb-83 \\
\hline & Oct-91 & Oct-91 & Sep-91 & Jun-87 & Jun-87 \\
\hline & & & Jan-99 & Apr-92 & Apr-92 \\
\hline & & & & & Jan-99 \\
\hline \multirow{4}{*}{ 4. Colombia } & Mar-83 & Jan-85 & Jan-85 & Jun-85 & Jun-85 \\
\hline & Feb-85 & & Sep-97 & & Nov-97 \\
\hline & & & Sep-98 & & \\
\hline & & & Jul-99 & & \\
\hline \multirow[t]{4}{*}{ 5. Denmark } & May-71 & Jun-73 & Jun-73 & no data & no data \\
\hline & Jun-73 & Nov-79 & Nov-79 & & \\
\hline & Nov-79 & Aug-93 & Aug-93 & & \\
\hline & Aug-93 & & & & \\
\hline \multirow[t]{4}{*}{ 6. Finland } & Jun-73 & Jun-73 & Jun-73 & Feb-78 & Feb-78 \\
\hline & Oct-92 & Apr-77 & Apr-77 & Sep-92 & Sep-92 \\
\hline & Nov-91 & Oct-82 & Oct-82 & & \\
\hline & Sep-92 & Sep-92 & Sep-92 & & \\
\hline \multirow{4}{*}{ 7. Indonesia } & Nov-78 & Nov-78 & Nov-78 & Dec-78 & Dec-78 \\
\hline & Apr-83 & Apr-83 & Apr-83 & Apr-83 & Apr-83 \\
\hline & Sep-86 & Sep-86 & Sep-86 & Oct-86 & Oct-86 \\
\hline & & & Dec-97 & & Sep-97 \\
\hline \multirow[t]{4}{*}{ 8. Israel } & Nov-74 & Nov-74 & Nov-74 & Nov-74 & Nov-74 \\
\hline & Nov-77 & Nov-77 & Nov-77 & Nov-77 & Nov-77 \\
\hline & Oct-83 & Oct-83 & Oct-83 & Nov-79 & Nov-79 \\
\hline & Jul-84 & Jul-84 & Jul-84 & Oct- 83 & Oct-83 \\
\hline \multirow[t]{4}{*}{ 9. Korea } & & Jun-71 & & & \\
\hline & & Dec-74 & & Sep-80 & Sep-80 \\
\hline & & Jan- 80 & Jan-80 & & Nov-97 \\
\hline & & & Nov-97 & & \\
\hline \multirow[t]{6}{*}{10 Malaysia } & Jul-75 & Nov-73 & & no data & \\
\hline & & Nov-78 & & & Oct-97 \\
\hline & & Mar-80 & & & \\
\hline & & Feb-85 & & & \\
\hline & & Dec-92 & & & \\
\hline & & & Jul-97 & & \\
\hline \multirow[t]{6}{*}{ 11. Mexico } & Sep-76 & Sep-76 & Sep-76 & Sep-76 & Sep-76 \\
\hline & Feb-82 & Feb-82 & Feb-82 & Feb-82 & Feb-82 \\
\hline & Dec-82 & Dec-82 & Dec-82 & Jul-85 & Jul-85 \\
\hline & Dec-94 & Dec-94 & Dec-94 & Dec-94 & Dec-94 \\
\hline & & & & & Aug-98 \\
\hline & & & & & \\
\hline
\end{tabular}




\begin{tabular}{|c|c|c|c|c|c|}
\hline \multirow{2}{*}{$\begin{array}{l}\text { Table } 3 \text { continued } \\
\text { Country }\end{array}$} & \multicolumn{3}{|c|}{ Exchange Rate Pressure Index } & \multicolumn{2}{|c|}{ Devaluation Episodes } \\
\hline & $\begin{array}{l}\text { Original KLR } \\
\text { Dates }\end{array}$ & $\begin{array}{l}\text { Replication of } \\
\text { KLR Crisis Date } \\
1970-1995^{1}\end{array}$ & $\begin{array}{c}\text { Replication of } \\
\text { KLR Crisis Date } \\
1970 \text { - } 1999\end{array}$ & $\begin{array}{c}\text { Frankel - Rose } \\
\text { Method 1970 - } \\
\text { 1995 }^{2}\end{array}$ & $\begin{array}{c}\text { Frankel - Rose } \\
\text { Method } 1970 \text { - } \\
1999\end{array}$ \\
\hline \multirow[t]{7}{*}{ 12. Peru } & Jun-76 & Jun-76 & Jun-76 & Jun-76 & Jun-76 \\
\hline & & & & Feb-81 & Feb-81 \\
\hline & Oct-87 & Oct-87 & Oct-87 & Jul-82 & Jul-82 \\
\hline & & & & Jan-85 & Jan-85 \\
\hline & & & & Oct-87 & Oct- 87 \\
\hline & & & & Sep-90 & Sep-90 \\
\hline & & & & Mar-93 & Mar-93 \\
\hline \multirow[t]{4}{*}{ 13. Philippines } & Feb-70 & Oct-83 & Oct- 83 & & \\
\hline & Oct-83 & Jun-84 & Jun-84 & Jun-83 & Jun-83 \\
\hline & Jun-84 & Feb-86 & Feb-86 & & Sep-97 \\
\hline & & & Dec-97 & & \\
\hline \multirow[t]{4}{*}{ 14. Portugal } & & Mar-76 & Mar-76 & & \\
\hline & & Feb-77 & Feb-77 & Feb-77 & Feb-77 \\
\hline & & Jun-82 & Jun-82 & Jul-82 & Jul-82 \\
\hline & & Jun-83 & Jun-83 & & \\
\hline \multirow[t]{5}{*}{ 15. South Africa } & & Sep-75 & Sep-75 & Feb-76 & Feb-76 \\
\hline & & Jul-84 & Jul-84 & Dec-81 & Dec-81 \\
\hline & & Aug-85 & Aug-85 & Jul-84 & Jul-84 \\
\hline & & May-86 & May-86 & & Oct-96 \\
\hline & & & Jun-98 & & Jun-98 \\
\hline \multirow[t]{6}{*}{ 16. Spain } & Feb-76 & Jun-73 & Jun-73 & & \\
\hline & Jul-77 & Feb-76 & Feb-76 & & \\
\hline & Dec-82 & Jul-77 & Jul-77 & Jul-77 & Jul-77 \\
\hline & Sep-92 & Mar-83 & Mar-83 & Jul-93 & Jul-93 \\
\hline & May-93 & Sep-92 & Sep-92 & & \\
\hline & & Mar-95 & Mar-95 & & \\
\hline \multirow[t]{4}{*}{ 17. Sweden } & Aug-77 & Aug-77 & Aug-77 & & \\
\hline & Sep-81 & Sep-81 & Sep-81 & Mar-78 & Mar-78 \\
\hline & Oct-82 & Oct-82 & Oct-82 & Feb-93 & Feb-93 \\
\hline & Nov-92 & Nov-92 & Nov-92 & & \\
\hline \multirow[t]{4}{*}{ 18. Thailand } & Nov-78 & Nov-78 & & no data & \\
\hline & Jul-81 & Jul-81 & & & Aug-97 \\
\hline & Nov-84 & Nov-84 & & & \\
\hline & & & Jul-97 & & \\
\hline \multirow[t]{9}{*}{ 19. Turkey } & Aug-70 & Aug-70 & Aug-70 & & \\
\hline & Jan- 80 & Jan- 80 & Jan-80 & Mar-78 & Mar-78 \\
\hline & Mar-94 & Mar-94 & Mar-94 & Jan-80 & Jan-80 \\
\hline & & & & Jan-82 & Jan-82 \\
\hline & & & & Jan-84 & Jan-84 \\
\hline & & & & Jan-88 & Jan-88 \\
\hline & & & & Feb-91 & Feb-91 \\
\hline & & & & Jan-94 & Jan-94 \\
\hline & & & & & Apr-96 \\
\hline \multirow[t]{6}{*}{ 20. Uruguay } & Dec-71 & Mar-72 & Mar-72 & Mar-72 & Mar-72 \\
\hline & Oct-82 & Nov-82 & Nov-82 & Nov-74 & Nov-74 \\
\hline & & & & Apr-77 & Apr-77 \\
\hline & & & & Nov-82 & Nov- 82 \\
\hline & & & & Dec-84 & Dec-84 \\
\hline & & & & Dec-89 & Dec-89 \\
\hline \multirow[t]{6}{*}{ 21. Venezuela } & Feb-84 & Mar-84 & Mar-84 & Mar-84 & Mar-84 \\
\hline & Dec-86 & Dec-86 & Dec-86 & Dec-86 & Dec-86 \\
\hline & Mar-89 & Mar-89 & Mar-89 & Mar-89 & Mar-89 \\
\hline & May-94 & & Dec-95 & May-93 & May-93 \\
\hline & Dec-95 & & & May-94 & May-94 \\
\hline & & & & & Mar-96 \\
\hline
\end{tabular}




\begin{tabular}{|c|c|c|c|c|c|}
\hline Table 3 continued & \multicolumn{3}{|c|}{ Exchange Rate Pressure Index } & \multicolumn{2}{|c|}{ Devaluation Episodes } \\
\hline Country & $\begin{array}{l}\text { Original KLR } \\
\text { Dates }\end{array}$ & $\begin{array}{c}\text { Replication of } \\
\text { KLR Crisis Date } \\
1970-1995^{1}\end{array}$ & $\begin{array}{l}\text { Replication of } \\
\text { KLR Crisis Date } \\
1970 \text { - } 1999\end{array}$ & $\begin{array}{c}\text { Frankel - Rose } \\
\text { Method } 1970 \text { - } \\
1_{1995^{2}}\end{array}$ & $\begin{array}{c}\text { Frankel - Rose } \\
\text { Method } 1970 \text { - } \\
1999\end{array}$ \\
\hline \multirow[t]{8}{*}{ 22. Chile } & Dec-71 & Jul-71 & Jul-71 & Jan-72 & Jan-72 \\
\hline & Aug-72 & Sep-72 & Sep-72 & May-73 & May-73 \\
\hline & & May-73 & May-73 & May-75 & May-75 \\
\hline & Oct-73 & Dec-74 & Dec-74 & Aug-82 & Aug-82 \\
\hline & Dec-74 & Jul-85 & Jul-85 & Jul-85 & Jul-85 \\
\hline & Jan-76 & & & & \\
\hline & Aug-82 & & & & \\
\hline & Sep-84 & & & & \\
\hline \multirow[t]{5}{*}{ 23. Norway } & Jun-73 & Jun-73 & Jun-73 & no data & no data \\
\hline & Feb-78 & Feb-78 & Feb-78 & & \\
\hline & May-86 & May-86 & May-86 & & \\
\hline & Dec-92 & Nov-92 & Nov-92 & & \\
\hline & & & Dec-97 & & \\
\hline \multirow[t]{5}{*}{ 24. Greece } & & Jan-83 & Jan-83 & Feb-81 & Feb-81 \\
\hline & & Oct- 85 & Sep-84 & Jan-83 & Jan-83 \\
\hline & & & Oct-85 & Dec-83 & Dec-83 \\
\hline & & & & Feb-85 & Feb-85 \\
\hline & & & & Jul-93 & Jul-93 \\
\hline \multirow[t]{2}{*}{ 25. India } & & Jul-91 & Apr-91 & Jul-91 & Jul-91 \\
\hline & & Mar-93 & Mar-93 & & \\
\hline \multirow[t]{2}{*}{ 26. Pakistan } & & May-72 & May-72 & May-72 & May-72 \\
\hline & & & & Oct- 82 & Oct-82 \\
\hline & & & & & \\
\hline & & & & & \\
\hline & & & & & \\
\hline & & & & & \\
\hline & & & & & \\
\hline & & & & & \\
\hline 27. Sri Lanka & & Nov-77 & Nov-77 & Nov-77 & Nov-77 \\
\hline 28. Singapore & & Dec-70 & Dec-70 & no data & no data \\
\hline & & Jul-75 & Jul-75 & & \\
\hline & & Nov-78 & & & \\
\hline & & Mar-80 & Mar-80 & & \\
\hline & & & Dec-97 & & \\
\hline
\end{tabular}

Notes: The KLR crises dates are derived from calculating an index of weighted average of exchange rate changes and reserve losses. The reading of this index that was 2.5 standard deviations or more above the mean was cataloged as a crises. The FR crises dates are define as a nominal depreciation of the currency of at least 25 percent and that this depreciation exceeds the previous year's change by a margin of at least 10 percent. 1. Crises are reported for the expanded sample and not just the KLR countries, using data thru April 1995. 2. Data from January 1970 - April 1995 are used to calculate Frankel-Rose crises.

Source: Author's calculation and Kaminsky, Lizondo and Reinhart (1998). 


\begin{tabular}{|l|c|c|}
\hline \multicolumn{3}{|c|}{ Table 4: Performance of an Indicator } \\
\hline & Crisis within 24 months & No crisis within 24 months \\
\hline Signal issued & A & B \\
\hline No signal issued & C & D \\
\hline
\end{tabular}

Note: Table gives a concise summary of the possible outcomes of a variable. We focus mainly on the entries of A and B, which are considered a signal (Cell A) and noise (Cell B). Note that a perfect indicator would have only entries in cells A and D. 


\begin{tabular}{|c|c|c|c|c|c|c|c|c|c|c|}
\hline \multicolumn{11}{|c|}{$\begin{array}{c}\text { Table } 5^{1} \\
\text { Performance of Indicators }\end{array}$} \\
\hline \multirow[b]{2}{*}{ Variables $^{4}$} & \multicolumn{5}{|c|}{ Rerun of KLR Sample ${ }^{2}$} & \multicolumn{5}{|c|}{ Original KLR Results ${ }^{3}$} \\
\hline & $\begin{array}{l}\text { Number of } \\
\text { Crises }^{5}\end{array}$ & $\begin{array}{l}\text { Critical } \\
\text { Region }^{6}\end{array}$ & \begin{tabular}{|l} 
Noise/Signal \\
Ratio $^{7}$
\end{tabular} & $\begin{array}{l}\text { Share of } \\
\text { Crisis Called }^{8}\end{array}$ & $\mathbf{P}(\text { Crisis/Signal })^{9}$ & $\begin{array}{l}\text { Number of } \\
\text { Crises }^{5}\end{array}$ & $\begin{array}{l}\text { Critical } \\
\text { Region }^{6}\end{array}$ & $\begin{array}{l}\text { Noise/Signal } \\
\text { Ratio }^{7}\end{array}$ & $\begin{array}{l}\text { Share of } \\
\text { Crisis Called }^{8}\end{array}$ & $\mathrm{P}(\text { Crisis/Signal })^{9}$ \\
\hline Reserves & 70 & 0.1 & 0.57 & 0.66 & 0.36 & 72 & 0.15 & 0.57 & 0.75 & 0.41 \\
\hline Exports & 70 & 0.1 & 0.52 & 0.77 & 0.39 & 72 & 0.1 & 0.42 & 0.85 & 0.49 \\
\hline Real Exchange Rate & 70 & 0.1 & 0.22 & 0.44 & 0.59 & 72 & 0.1 & 0.19 & 0.57 & 0.67 \\
\hline Index of Equity Prices & 41 & 0.2 & 0.57 & 0.62 & 0.32 & 53 & 0.11 & 0.47 & 0.64 & 0.49 \\
\hline Commercial Bank Deposits & 69 & 0.1 & 1.05 & 0.32 & 0.23 & 69 & 0.1 & 1.2 & 0.49 & 0.25 \\
\hline Output & 51 & 0.12 & 0.57 & 0.61 & 0.39 & 57 & 0.11 & 0.52 & 0.77 & 0.49 \\
\hline Excess M1 balances & 68 & 0.1 & 0.6 & 0.50 & 0.35 & 66 & 0.16 & 0.52 & 0.61 & 0.43 \\
\hline M2 Multiplier & 70 & 0.15 & 0.89 & 0.64 & 0.26 & 70 & 0.14 & 0.61 & 0.73 & 0.4 \\
\hline M2/Reserves & 70 & 0.1 & 0.54 & 0.63 & 0.37 & 70 & 0.13 & 0.48 & 0.80 & 0.46 \\
\hline Domestic Credit/GDP & 67 & 0.1 & 0.63 & 0.43 & 0.33 & 62 & 0.1 & 0.62 & 0.56 & 0.39 \\
\hline Real Interest Rates & 49 & 0.15 & 0.69 & 0.37 & 0.26 & 44 & 0.12 & 0.77 & 0.89 & 0.34 \\
\hline Real Int. Rate Differential & 49 & 0.1 & 1.2 & 0.18 & 0.17 & 42 & 0.11 & 0.99 & 0.86 & 0.29 \\
\hline Lending/Deposit Ratio & 36 & 0.2 & 2.3 & 0.28 & 0.08 & 33 & 0.2 & 1.69 & 0.67 & 0.18 \\
\hline Imports & 70 & 0.1 & 1.2 & 0.48 & 0.21 & 71 & 0.1 & 1.16 & 0.54 & 0.26 \\
\hline
\end{tabular}

Notes: 1. Estimation period January 1970 to December 1995 (320 observations) using 20 Countries (Argentina, Bolivia, Brazil, Colombia, Denmark, Finland, Indonesia, Israel, Malaysia, Mexico, Peru, Philippines, Spain, Sweden, Thailand, Turkey, Uruguay, Venezuela, Chile, and Norway). 2. Source: Author's calculations. 3. Source KLR (1998). 4. Variables are measured as 12-month percentage changes, except interest rates (12-month level change), real exchange rate (deviation from trend), and excess M1 (residual from M1 equation). 5. Number of crises for which data exist for this variable. 6. Critical region used to determine the "optimal threshold". 7. Ratio of false signals to total number of months there is no crisis relative to proportion of good signals- in terms of Table 4 this is: $[B /(B+D)] /[A /(A+C)]$. 8. Defined as the number of crises for which indicator issued at least one signal during the twenty-four months prior to the crisis. 9. Probability of a crisis: $\mathrm{A} /(\mathrm{A}+\mathrm{B})$ given a signal was issued. 


\begin{tabular}{|c|c|c|c|c|c|c|}
\hline \multicolumn{7}{|c|}{$\begin{array}{c}\text { Table } 6 \\
\text { Summary Results - Benchmark } \text { Model }^{1}\end{array}$} \\
\hline Variable $^{2}$ & Number of Crises ${ }^{3}$ & Number of Countries & Size of Critical Region ${ }^{4}$ & Noise-to-Signal Ratio ${ }^{5}$ & Probability of Crisis ${ }^{6}$ & Share of Crises Called \\
\hline Reserves & 89 & 28 & 0.1 & 0.53 & 0.36 & 0.66 \\
\hline Exports & 89 & 28 & 0.1 & 0.60 & 0.33 & 0.72 \\
\hline Real Exchange Rates & 91 & 28 & 0.1 & 0.26 & 0.53 & 0.44 \\
\hline Index of Equity Prices & 48 & 17 & 0.2 & 0.57 & 0.28 & 0.63 \\
\hline Commercial Bank Deposit & 75 & 25 & 0.1 & 0.94 & 0.21 & 0.35 \\
\hline Output Index & 66 & 21 & 0.14 & 0.59 & 0.34 & 0.68 \\
\hline Excess real M1 balances & 44 & 21 & 0.1 & 0.55 & 0.25 & 0.52 \\
\hline M2 Multiplier & 83 & 28 & 0.15 & 0.86 & 0.24 & 0.63 \\
\hline M2/Reserves & 83 & 28 & 0.1 & 0.52 & 0.34 & 0.61 \\
\hline Domestic Credit - GDP ratio & 72 & 25 & 0.2 & 0.75 & 0.25 & 0.67 \\
\hline Real Interest Rate & 60 & 23 & 0.2 & 0.66 & 0.26 & 0.53 \\
\hline Real Interest Diff. & 58 & 23 & 0.1 & 1 & 0.19 & 0.26 \\
\hline Lending/Deposit Ratio & 43 & 18 & 0.2 & 2.7 & 0.06 & 0.28 \\
\hline Imports & 89 & 28 & 0.1 & 0.88 & 0.25 & 0.52 \\
\hline US Output & 89 & 28 & 0.1 & 0.58 & 0.33 & 0.45 \\
\hline G-7 Output & 89 & 28 & 0.1 & 0.58 & 0.33 & 0.36 \\
\hline US Interest Rate & 89 & 28 & 0.1 & 0.97 & 0.23 & 0.37 \\
\hline Oil Prices & 89 & 28 & 0.1 & 0.99 & 0.23 & 0.28 \\
\hline Level of M2/Reserves & 86 & 28 & 0.12 & 0.47 & 0.36 & 0.50 \\
\hline Change in STD/Reserves & 12 & 8 & 0.12 & 0.4 & 0.15 & 0.92 \\
\hline Level of STD/Reserves & 14 & 9 & 0.12 & 0.47 & 0.13 & 0.57 \\
\hline
\end{tabular}

Notes: Estimation period January 1970 to April 1995 using 28 countries (Argentina, Bolivia, Brazil, Colombia, Denmark, Finland, Indonesia, Israel, Korea,

Malaysia, Mexico, Peru, Philippines, Portugal, South Africa, Spain, Sweden, Thailand, Turkey, Uruguay, Venezuela, Chile, Norway, Greece, India, Pakistan, Sri Lanka, and Singapore). 2. Variables are measured as 12-month percentage changes, except interest rates (12-month level change), real exchange rate (deviation from trend) and excess M1 ( residual from M1 equation). 3. Number of crises for which data exist for this variable. 4. Critical region used to determine the "optimal threshold" 5. Ratio of false signals to total number of months there is no crisis relative to proportion of good signals - in terms of Table 4 this is: $[\mathrm{B} /(\mathrm{B}+\mathrm{D})] /[\mathrm{A} /(\mathrm{A}+\mathrm{C})]$. 6. Probability of a crisis $\mathrm{A} /(\mathrm{A}+\mathrm{B})$ given a signal was issued. 7. Defined as the number of crises for which indicator issued at least one signal during the twenty-four months prior to the crisis.

Source: Author's calculations. 


\begin{tabular}{|c|c|c|c|c|c|c|c|c|c|}
\hline \multicolumn{10}{|c|}{ Table 7: Summary of Prediction: Latin America } \\
\hline & \multicolumn{3}{|c|}{ Argentina } & \multicolumn{3}{|c|}{ Brazil } & \multicolumn{3}{|c|}{ Mexico } \\
\hline Dates & $\begin{array}{c}\text { Number of } \\
\text { Available } \\
\text { Indicators }{ }^{1}\end{array}$ & $\begin{array}{c}\text { Number of } \\
\text { Signals }^{2}\end{array}$ & $\begin{array}{l}\text { Noise-to Signal } \\
\text { Weighted } \\
\text { Composite }^{3}\end{array}$ & $\begin{array}{c}\text { Number of } \\
\text { Available } \\
\text { Indicators }\end{array}$ & $\begin{array}{c}\begin{array}{c}\text { Number } \\
\text { of } \\
\text { Signals }^{2}\end{array}\end{array}$ & $\begin{array}{c}\text { Noise-to Signal } \\
\text { Weighted } \\
\text { Composite Index }\end{array}$ & $\begin{array}{c}\text { Number of } \\
\text { Available } \\
\text { Indicators }\end{array}$ & $\begin{array}{c}\begin{array}{c}\text { Number } \\
\text { of } \\
\text { Signals }^{2}\end{array}\end{array}$ & $\begin{array}{c}\text { Noise-to Signal } \\
\text { Weighted } \\
\text { Composite Index }\end{array}$ \\
\hline May-95 & 15 & 1 & 1.06 & 15 & 4 & 7.33 & 16 & 2 & 3.44 \\
\hline Jun-95 & 15 & 1 & 1.06 & 15 & 4 & 7.33 & 16 & 2 & 3.44 \\
\hline Jul-95 & 15 & 1 & 1.06 & 15 & 2 & 2.9 & 16 & 2 & 3.44 \\
\hline Aug-95 & 15 & 1 & 1.06 & 15 & 1 & 1.76 & 16 & 2 & 3.44 \\
\hline Oct-95 & 15 & 3 & 4.51 & 15 & 1 & 1.76 & 16 & 2 & 3.44 \\
\hline Nov-95 & 15 & 2 & 2.75 & 15 & 1 & 1.76 & 16 & 2 & 3.44 \\
\hline Dec-95 & 15 & 2 & 2.75 & 15 & 3 & 4.65 & 16 & 1 & 1.68 \\
\hline Jan-96 & 15 & 1 & 1.06 & 15 & 2 & 2.83 & 16 & 0 & 0 \\
\hline Feb-96 & 15 & 1 & 1.06 & 15 & 2 & 2.83 & 16 & 0 & 0 \\
\hline Mar-96 & 15 & 1 & 1.06 & 15 & 2 & 2.83 & 16 & 0 & 0 \\
\hline Apr-96 & 15 & 0 & 0 & 15 & 2 & 2.83 & 16 & 0 & 0 \\
\hline May-96 & 15 & 0 & 0 & 15 & 2 & 2.83 & 16 & 0 & 0 \\
\hline Jun-96 & 15 & 0 & 0 & 15 & 2 & 2.83 & 16 & 0 & 0 \\
\hline Sep-96 & 15 & 2 & 2.73 & 15 & 3 & 4.65 & 16 & 0 & 0 \\
\hline Oct-96 & 15 & 1 & 1.06 & 15 & 3 & 5.35 & 16 & 0 & 0 \\
\hline Nov-96 & 15 & 1 & 1.06 & 15 & 4 & 7.17 & 16 & 0 & 0 \\
\hline Dec-96 & 15 & 1 & 1.06 & 15 & 4 & 7.17 & 16 & 0 & 0 \\
\hline Jan-97 & 15 & 1 & 1.06 & 15 & 4 & 7.17 & 16 & 1 & 1.34 \\
\hline Feb-97 & 15 & 1 & 1.06 & 15 & 4 & 7.17 & 16 & 1 & 1.34 \\
\hline Mar-97 & 15 & 1 & 1.06 & 15 & 4 & 7.17 & 16 & 1 & 1.34 \\
\hline Apr-97 & 15 & 1 & 1.06 & 15 & 4 & 7.17 & 16 & 1 & 1.34 \\
\hline May-97 & 15 & 1 & 1.06 & 15 & 3 & 5.41 & 16 & 1 & 1.34 \\
\hline Jun-97 & 15 & 1 & 1.06 & 15 & 3 & 5.41 & 16 & 1 & 1.34 \\
\hline Jul-97 & 15 & 0 & 0 & 15 & 3 & 5.41 & 16 & 1 & 1.34 \\
\hline Aug-97 & 15 & 0 & 0 & 15 & 4 & 7.17 & 16 & 1 & 1.34 \\
\hline Sep-97 & 15 & 0 & 0 & 15 & 4 & 7.17 & 15 & 1 & 1.34 \\
\hline Oct-97 & 15 & 0 & 0 & 15 & 4 & 7.17 & 15 & 1 & 1.34 \\
\hline Nov-97 & 15 & 0 & 0 & 15 & 4 & 7.17 & 15 & 1 & 1.34 \\
\hline Dec-97 & 15 & 0 & 0 & 15 & 4 & 7.17 & 16 & 1 & 1.34 \\
\hline Jan-98 & 15 & 0 & 0 & 14 & 4 & 7.17 & 16 & 0 & 0 \\
\hline Feb-98 & 15 & 0 & 0 & 14 & 4 & 7.17 & 16 & 0 & 0 \\
\hline Jun-98 & 15 & 2 & 2.83 & 14 & 4 & 5.98 & 16 & 1 & 1.76 \\
\hline
\end{tabular}




\begin{tabular}{|c|c|c|c|c|c|c|c|c|c|}
\hline \multirow[b]{2}{*}{ Dates } & \multicolumn{3}{|c|}{ Argentina } & \multicolumn{3}{|c|}{ Brazil } & \multicolumn{3}{|c|}{ Mexico } \\
\hline & $\begin{array}{c}\text { Number of } \\
\text { Available } \\
\text { Indicators }^{1}\end{array}$ & $\begin{array}{c}\text { Number of } \\
\text { Signals }^{2}\end{array}$ & $\begin{array}{l}\text { Noise-to Signal } \\
\text { Weighted } \\
\text { Composite }^{3}\end{array}$ & $\begin{array}{l}\text { Number of } \\
\text { Available } \\
\text { Indicators }^{1}\end{array}$ & $\begin{array}{c}\text { Number } \\
\text { of } \\
\text { Signals }^{2}\end{array}$ & $\begin{array}{c}\text { Noise-to Signal } \\
\text { Weighted } \\
\text { Composite Index }\end{array}$ & $\begin{array}{c}\text { Number of } \\
\text { Available } \\
\text { Indicators }^{1}\end{array}$ & $\begin{array}{c}\text { Number } \\
\text { of } \\
\text { Signals }^{2}\end{array}$ & $\begin{array}{c}\text { Noise-to Signal } \\
\text { Weighted } \\
\text { Composite Index }\end{array}$ \\
\hline Jul-98 & 15 & 2 & 2.83 & 14 & 3 & 4.65 & 16 & 1 & 1.76 \\
\hline Aug-98 & 15 & 2 & 2.83 & 14 & 4 & 6.31 & 16 & 1 & 1.76 \\
\hline Sep-98 & 15 & 2 & 2.83 & 14 & 5 & 8.51 & 15 & 1 & 1.76 \\
\hline Oct-98 & 15 & 2 & 2.83 & 14 & 6 & 10 & 15 & 1 & 1.76 \\
\hline Dec-98 & 15 & 3 & 4.51 & 14 & 4 & 5.98 & 16 & 1 & 1.76 \\
\hline $\begin{array}{l}\text { Jan-99 } \\
\end{array}$ & 14 & 3 & 4.51 & 12 & 4 & 7.01 & 16 & 1 & 1.76 \\
\hline Feb-99 & 14 & 2 & 2.83 & 12 & 4 & 7.25 & 16 & 1 & 1.76 \\
\hline Mar-99 & 14 & 3 & 4.51 & 12 & 4 & 7.25 & 16 & 1 & 1.76 \\
\hline Apr-99 & 14 & 2 & 2.75 & 12 & 6 & 10.08 & 16 & 1 & 1.76 \\
\hline May-99 & 14 & 2 & 2.75 & 12 & 4 & 7.25 & 16 & 0 & 0 \\
\hline Jun-99 & 14 & 2 & 2.75 & 12 & 5 & 8.42 & 16 & 0 & 0 \\
\hline Jul-99 & 13 & 2 & 2.75 & 11 & 4 & 6.39 & 13 & 0 & 0 \\
\hline Aug-99 & 11 & 1 & 1.06 & 11 & 4 & 5.89 & 12 & 0 & 0 \\
\hline Oct-99 & 7 & 1 & 1.01 & 6 & 2 & 2.78 & 5 & 1 & 1.01 \\
\hline Nov-99 & 4 & 1 & 1.01 & 2 & 1 & 1.01 & 2 & 1 & 1.01 \\
\hline Dec-99 & 3 & 1 & 1.01 & 2 & 1 & 1.01 & 2 & 1 & 1.01 \\
\hline
\end{tabular}

Notes: The results are based on a subset of indicators reported in Table 6 . The indicators used in this table include: foreign exchange reserves, exports, deviation of the real exchange rate from trend, equity prices, commercial bank deposits, output, excess money supply, M2 multiplier, M2/reserves, short-term debt/reserves, domestic credit/GDP, real domestic interest rates, imports, G7 income growth, changes in US interest rates, and oil prices. 1. Number of available indicators for the time period. 2. Number of indicators that were signaling. 3. Weighted sum of indicators signal with weights given by the signal-to-noise ratio.

Source: Author's calculations. 


\begin{tabular}{|c|c|c|c|c|c|c|c|c|c|c|c|c|c|c|c|}
\hline \multicolumn{16}{|c|}{ Table 8: Summary of Prediction: Asia } \\
\hline & \multicolumn{3}{|c|}{ Indonesia } & \multicolumn{3}{|c|}{ Korea } & \multicolumn{3}{|c|}{ Malaysia } & \multicolumn{3}{|c|}{ Philippines } & \multicolumn{3}{|c|}{ Thailand } \\
\hline Dates & $\begin{array}{c}\text { Total } \\
\text { Number } \\
\text { of } \\
\text { Indicators }^{1}\end{array}$ & $\begin{array}{c}\text { Number of } \\
\text { Signals }^{2}\end{array}$ & $\begin{array}{c}\text { Weighted } \\
\text { Index }^{3}\end{array}$ & \begin{tabular}{|c|} 
Total \\
Number \\
of \\
Indicators $^{1}$
\end{tabular} & $\begin{array}{c}\text { Number of } \\
\text { Signals }^{2}\end{array}$ & $\begin{array}{c}\text { Weighted } \\
\text { Index }^{3}\end{array}$ & $\begin{array}{c}\text { Total } \\
\text { Number } \\
\text { of } \\
\text { Indicators }^{1}\end{array}$ & $\begin{array}{c}\text { Number of } \\
\text { Signals }^{2}\end{array}$ & $\begin{array}{c}\text { Weighted } \\
\text { Index }^{3}\end{array}$ & $\begin{array}{c}\text { Total } \\
\text { Number } \\
\text { of } \\
\text { Indicators }\end{array}$ & $\begin{array}{c}\text { Number of } \\
\text { Signals }^{2}\end{array}$ & $\begin{array}{c}\text { Weighted } \\
\text { Index }^{3}\end{array}$ & $\begin{array}{c}\text { Total } \\
\text { Number } \\
\text { of } \\
\text { Indicators }^{1}\end{array}$ & $\begin{array}{c}\text { Number of } \\
\text { Signals }^{2}\end{array}$ & $\begin{array}{c}\text { Weighted } \\
\text { Index }^{3}\end{array}$ \\
\hline May-95 & 14 & 0 & 0 & 16 & 1 & 3.83 & 16 & 3 & 7.64 & 15 & 2 & 2.5 & 15 & 3 & 6.99 \\
\hline Jun-95 & 14 & 0 & 0 & 16 & 1 & 3.83 & 16 & 4 & 8.78 & 15 & 1 & 1.16 & 15 & 2 & 5.17 \\
\hline Jul-95 & 14 & 0 & 0 & 16 & 2 & 4.9 & 16 & 4 & 8.98 & 15 & 2 & 2.5 & 15 & 2 & 5.17 \\
\hline Aug-95 & 14 & 0 & 0 & 16 & 1 & 3.83 & 16 & 3 & 5.15 & 15 & 1 & 1.34 & 15 & 3 & 6.93 \\
\hline Sep-95 & 14 & 0 & 0 & 16 & 2 & 4.9 & 16 & 2 & 3.81 & 15 & 1 & 1.34 & 15 & 2 & 5.59 \\
\hline Oct-95 & 14 & 0 & 0 & 16 & 1 & 3.83 & 16 & 3 & 5.57 & 15 & 3 & 4.26 & 15 & 2 & 5.59 \\
\hline Nov-95 & 14 & 1 & 1.68 & 16 & 3 & 6.58 & 16 & 3 & 6.33 & 15 & 3 & 4.26 & 15 & 2 & 5.59 \\
\hline Dec-95 & 14 & 1 & 1.68 & 16 & 4 & 9.1 & 16 & 1 & 1.91 & 15 & 0 & 0 & 15 & 2 & 5.59 \\
\hline Jan-96 & 14 & 0 & 0 & 16 & 2 & 4.9 & 16 & 3 & 6.25 & 15 & 2 & 2.5 & 15 & 1 & 3.83 \\
\hline Feb-96 & 14 & 0 & 0 & 16 & 2 & 5.65 & 16 & 3 & 6.25 & 15 & 4 & 7.48 & 15 & 2 & 5.65 \\
\hline Mar-96 & 14 & 1 & 1.51 & 16 & 3 & 7.33 & 16 & 3 & 6.25 & 15 & 2 & 5.17 & 15 & 3 & 7.32 \\
\hline Apr-96 & 14 & 0 & 0 & 16 & 2 & 5.65 & 16 & 4 & 10.08 & 15 & 3 & 6.99 & 15 & 1 & 3.83 \\
\hline May-96 & 14 & 0 & 0 & 16 & 2 & 5 & 16 & 4 & 10.08 & 15 & 2 & 5.17 & 15 & 3 & 7.41 \\
\hline Jun-96 & 14 & 1 & 1.51 & 16 & 2 & 5 & 16 & 4 & 9.95 & 15 & 2 & 5.17 & 15 & 3 & 7.26 \\
\hline Jul-96 & 14 & 0 & 0 & 16 & 3 & 6.66 & 16 & 3 & 8.26 & 15 & 2 & 5.17 & 15 & 2 & 5.59 \\
\hline Aug-96 & 14 & 0 & 0 & 16 & 4 & 8 & 16 & 2 & 6.36 & 15 & 2 & 5.17 & 15 & 2 & 5.59 \\
\hline Sep-96 & 14 & 0 & 0 & 16 & 4 & 6.58 & 16 & 3 & 7.7 & 15 & 3 & 6.93 & 15 & 3 & 7.26 \\
\hline Oct-96 & 14 & 0 & 0 & 16 & 2 & 3.1 & 16 & 2 & 5.17 & 15 & 3 & 6.93 & 15 & 3 & 6.66 \\
\hline Nov-96 & 14 & 0 & 0 & 16 & 3 & 4.26 & 16 & 2 & 5.17 & 15 & 2 & 5.17 & 15 & 4 & 8.32 \\
\hline Dec-96 & 14 & 0 & 0 & 16 & 3 & 4.26 & 16 & 2 & 5.17 & 15 & 2 & 5.17 & 15 & 3 & 6.66 \\
\hline Jan-97 & 14 & 0 & 0 & 16 & 4 & 5.93 & 16 & 3 & 6.99 & 15 & 3 & 6.93 & 15 & 3 & 6.66 \\
\hline Feb-97 & 14 & 0 & 0 & 16 & 6 & 10.27 & 16 & 3 & 6.99 & 15 & 1 & 3.83 & 15 & 4 & 8.32 \\
\hline Mar-97 & 14 & 0 & 0 & 16 & 4 & 5.93 & 16 & 3 & 6.99 & 15 & 2 & 5.65 & 15 & 3 & 6.66 \\
\hline Apr-97 & 14 & 0 & 0 & 16 & 4 & 6.79 & 16 & 4 & 9.52 & 15 & 4 & 8.58 & 15 & 4 & 8 \\
\hline May-97 & 14 & 0 & 0 & 16 & 3 & 4.26 & 16 & 3 & 7.7 & 15 & 3 & 7.41 & 15 & 6 & 9.9 \\
\hline Jun-97 & 14 & 0 & 0 & 16 & 2 & 2.5 & 16 & 3 & 7.7 & 15 & 4 & 8.58 & 15 & 6 & 9.9 \\
\hline Jul-97 & 14 & 0 & 0 & 16 & 2 & 2.5 & 16 & 4 & 7.67 & 15 & 4 & 6.85 & 15 & 4 & 7.53 \\
\hline Aug-97 & 14 & 1 & 1.51 & 16 & 2 & 2.5 & 16 & 4 & 7.53 & 15 & 3 & 5.03 & 15 & 5 & 7.53 \\
\hline Sep-97 & 14 & 1 & 1.51 & 16 & 3 & 4.26 & 16 & 4 & 7.53 & 15 & 3 & 5.03 & 15 & 3 & 5 \\
\hline Oct-97 & 14 & 2 & 3.19 & 16 & 3 & 4.26 & 16 & 5 & 9.03 & 15 & 2 & 3.86 & 15 & 3 & 5 \\
\hline Nov-97 & 14 & 1 & 1.51 & 16 & 5 & 7.85 & 16 & 5 & 9.03 & 15 & 2 & 4.28 & 15 & 4 & 7.53 \\
\hline Dec-97 & 14 & 1 & 1.51 & 16 & 6 & 10.37 & 16 & 6 & 10.7 & 15 & 3 & 5.45 & 15 & 3 & 5 \\
\hline Jan-98 & 14 & 1 & 1.34 & 16 & 4 & 6.69 & 14 & 6 & 11.04 & 15 & 3 & 5.62 & 15 & 4 & 6.67 \\
\hline
\end{tabular}




\begin{tabular}{|c|c|c|c|c|c|c|c|c|c|c|c|c|c|c|c|}
\hline \multicolumn{16}{|c|}{ Table 8 continued } \\
\hline \multirow[b]{2}{*}{ Dates } & \multicolumn{3}{|c|}{ Indonesia } & \multicolumn{3}{|c|}{ Korea } & \multicolumn{3}{|c|}{ Malaysia } & \multicolumn{3}{|c|}{ Philippines } & \multicolumn{3}{|c|}{ Thailand } \\
\hline & $\begin{array}{c}\text { Total } \\
\text { Number } \\
\text { of } \\
\text { Indicators }^{1}\end{array}$ & $\begin{array}{c}\text { Number of } \\
\text { Signals }^{2}\end{array}$ & $\begin{array}{l}\text { Weighted } \\
\text { Index }^{3}\end{array}$ & $\begin{array}{c}\text { Total } \\
\text { Number } \\
\text { of } \\
\text { Indicators }^{1}\end{array}$ & $\begin{array}{c}\text { Number of } \\
\text { Signals }^{2}\end{array}$ & $\begin{array}{l}\text { Weighted } \\
\text { Index }^{3}\end{array}$ & $\begin{array}{c}\text { Total } \\
\text { Number } \\
\text { of } \\
\text { Indicators }^{1}\end{array}$ & $\begin{array}{c}\text { Number of } \\
\text { Signals }^{2}\end{array}$ & $\begin{array}{l}\text { Weighted } \\
\text { Index }^{3}\end{array}$ & $\begin{array}{c}\text { Total } \\
\text { Number } \\
\text { of } \\
\text { Indicators }^{1}\end{array}$ & $\begin{array}{c}\text { Number of } \\
\text { Signals }^{2}\end{array}$ & $\begin{array}{l}\text { Weighted } \\
\text { Index }^{3}\end{array}$ & \begin{tabular}{|c|} 
Total \\
Number \\
of \\
Indicators $^{1}$
\end{tabular} & $\begin{array}{c}\text { Number of } \\
\text { Signals }^{2}\end{array}$ & $\begin{array}{l}\text { Weighted } \\
\text { Index }^{3}\end{array}$ \\
\hline Feb-98 & 14 & 1 & 1.34 & 16 & 4 & 5.94 & 14 & 6 & 10.54 & 15 & 2 & 3.86 & 15 & 3 & 5 \\
\hline Mar-98 & 14 & 2 & 2.84 & 16 & 5 & 7.35 & 14 & 7 & 12.2 & 15 & 3 & 5.51 & 15 & 4 & 6.17 \\
\hline Apr-98 & 14 & 3 & 4.53 & 16 & 5 & 7.45 & 14 & 5 & 8.02 & 15 & 2 & 2.98 & 15 & 3 & 5 \\
\hline May-98 & 14 & 2 & 2.84 & 16 & 6 & 9.11 & 14 & 6 & 9.68 & 15 & 2 & 2.98 & 15 & 4 & 6.67 \\
\hline Jun-98 & 14 & 2 & 2.84 & 16 & 5 & 7.61 & 14 & 6 & 9.68 & 15 & 2 & 2.92 & 15 & 5 & 7.83 \\
\hline Jul-98 & 14 & 2 & 2.84 & 16 & 5 & 7.61 & 14 & 5 & 7.78 & 15 & 2 & 2.92 & 15 & 5 & 7.67 \\
\hline Aug-98 & 14 & 1 & 1.51 & 16 & 5 & 7.61 & 14 & 5 & 7.78 & 15 & 2 & 2.92 & 15 & 4 & 5.65 \\
\hline Sep-98 & 14 & 1 & 1.51 & 16 & 5 & 7.61 & 14 & 3 & 4.61 & 15 & 2 & 2.92 & 15 & 3 & 4.59 \\
\hline Oct-98 & 14 & 1 & 1.51 & 16 & 5 & 7.61 & 14 & 3 & 4.61 & 15 & 2 & 2.92 & 15 & 4 & 5.65 \\
\hline Nov-98 & 14 & 2 & 3.17 & 16 & 5 & 7.61 & 14 & 2 & 2.85 & 15 & 3 & 4.59 & 15 & 3 & 4.49 \\
\hline Dec-98 & 14 & 2 & 3.17 & 16 & 3 & 4.18 & 14 & 3 & 3.91 & 15 & 2 & 2.23 & 15 & 3 & 4.05 \\
\hline Jan-99 & 13 & 2 & 3.17 & 16 & 2 & 2.5 & 14 & 3 & 3.91 & 15 & 2 & 2.23 & 13 & 4 & 3.99 \\
\hline Feb-99 & 13 & 1 & 1.51 & 16 & 3 & 4.17 & 13 & 1 & 1.76 & 15 & 2 & 2.92 & 13 & 4 & 5.65 \\
\hline Mar-99 & 13 & 1 & 1.51 & 16 & 3 & 4.17 & 11 & 1 & 1.76 & 15 & 2 & 3.58 & 13 & 3 & 4.49 \\
\hline Apr-99 & 11 & $\frac{1}{1}$ & 1.51 & 16 & 2 & 3 & 11 & 0 & 0 & 15 & 1 & 1.82 & 13 & 2 & 2.23 \\
\hline May-99 & 11 & 2 & 2.67 & 16 & 1 & 1.34 & 11 & 0 & 0 & 15 & 1 & 1.82 & 13 & 2 & 2.23 \\
\hline Jun-99 & 10 & 2 & 2.57 & 16 & 2 & 2.5 & 11 & 0 & 0 & 15 & $\frac{1}{1}$ & $\begin{array}{l}1.02 \\
1.82\end{array}$ & 13 & $\frac{2}{1}$ & 1.06 \\
\hline Jul-99 & 9 & 4 & 5.64 & 13 & $\frac{2}{1}$ & 1.16 & 10 & 0 & 0 & 12 & $\frac{1}{1}$ & 1.02 & 12 & $\frac{1}{1}$ & 1.06 \\
\hline Aug-99 & 9 & 1 & 1.51 & 13 & 0 & 0 & 5 & 0 & 0 & 10 & 0 & 0 & 10 & $\frac{1}{1}$ & 1.06 \\
\hline Sep-99 & 5 & 0 & 0 & 8 & 0 & 0 & 5 & 0 & 0 & 7 & 0 & 0 & 10 & 1 & 1.06 \\
\hline Oct-99 & 3 & 1 & 1.01 & 6 & 1 & 1.01 & 5 & 1 & 1.01 & 3 & 1 & 1.01 & 5 & 1 & 1.01 \\
\hline Nov-99 & 2 & 1 & 1.01 & 2 & 1 & 1.01 & 3 & 1 & 1.01 & 2 & 1 & 1.01 & 3 & 1 & 1.01 \\
\hline Dec-99 & 2 & $\frac{1}{1}$ & 1.01 & 2 & $\frac{1}{1}$ & $\begin{array}{l}1.01 \\
1.01\end{array}$ & 2 & $\frac{1}{1}$ & $\begin{array}{l}1.01 \\
1.01\end{array}$ & 2 & $\frac{1}{1}$ & $\begin{array}{l}1.01 \\
1.01 \\
\end{array}$ & 3 & $\frac{1}{1}$ & 1.01 \\
\hline
\end{tabular}

Notes: The results are based on a subset of indicators reported in Table 6 . The indicators used in this table include: foreign exchange reserves, exports, deviation of the real exchange rate from trend, equity prices, commercial bank deposits, output, excess money supply, M2 multiplier, M2/reserves, short-term debt/reserves, domestic credit/GDP, real domestic interest rates, imports, G7 income growth, changes in US interest rates, and oil prices. 1. Number of available indicators for the time period. 2. Number of indicators that were signaling. 3 . Weighted sum of indicators signal with weights given by the signal-to-noise ratio.

Source: Author's calculations. 


\begin{tabular}{|c|c|}
\hline \multicolumn{2}{|c|}{ Table 9: Conditional Probabilities of Financial Crises } \\
\hline Value of Composite Index & Probability of Crisis \\
\hline $0-0.6$ & .14 \\
\hline $0.6-1.2$ & .12 \\
\hline $1.2-3$ & .17 \\
\hline $3-5$ & .25 \\
\hline $5-7$ & .32 \\
\hline $7-9$ & .33 \\
\hline $9-10$ & .43 \\
\hline $10-11$ & .51 \\
\hline $11-12$ & .29 \\
\hline Over 12 & .50 \\
\hline $\begin{array}{l}\text { Note: Table calculates the conditional probabilities using the weighted composite index. } \\
\text { Source: Author's calculations. }\end{array}$ \\
\hline
\end{tabular}




\section{Table 10}

\section{A Cross-Sectional View of the Out-of-Sample Performance -- December 1996}

\begin{tabular}{|c|c|c|c|c|c|c|c|c|c|c|c|c|c|c|c|c|c|c|c|c|}
\hline Country & Crisis Prob. & \# of Ind & \# of $\mathrm{Sig}$ & Wt Sigs & Reserve & Export & RER & Stock Price & Bank Dep & Output & EM1 & \begin{tabular}{|l} 
M2 \\
Mult \\
\end{tabular} & $\mathrm{M} 2 / \mathrm{R}$ & DC/GDP & Real Int & Imports & G7 & US Int & Oil s & $\mathrm{STD} / \mathrm{R}$ \\
\hline Argentina & 0.12 & 15 & 1 & 1.06 & & & & & $\mathrm{X}$ & & & & & & & & & & & \\
\hline Bolivia & 0.14 & 14 & 0 & 0.00 & & & & & & & & & & & & & & & & \\
\hline Brazil & 0.33 & 15 & 4 & 7.17 & & & & $X$ & $X$ & & $X$ & & & & & & & & & $X$ \\
\hline Colombia & 0.33 & 16 & 3 & 7.33 & & & $X$ & & & $X$ & $\mathrm{X}$ & & & & & & & & & \\
\hline Indonesia & 0.14 & 14 & 0 & 0.00 & & & & & & & & & & & & & & & & \\
\hline Israel & 0.17 & 14 & 1 & 1.76 & & & & $\mathrm{X}$ & & & & & & & & & & & & \\
\hline Korea & 0.25 & 16 & 3 & 4.26 & & & & $\mathrm{X}$ & & & & $X$ & & $\mathrm{X}$ & & & & & & \\
\hline Malaysia & 0.32 & 16 & 2 & 5.17 & & & $X$ & & & & & & & $\mathrm{X}$ & & & & & & \\
\hline Mexico & 0.14 & 16 & 0 & 0.00 & & & & & & & & & & & & & & & & \\
\hline Peru & 0.17 & 16 & 1 & 1.76 & & & & $\mathrm{X}$ & & & & & & & & & & & & \\
\hline Philippines & 0.32 & 15 & 2 & 5.17 & & & $\mathrm{X}$ & & & & & & & $\mathrm{X}$ & & & & & & \\
\hline South Africa & 0.43 & 16 & 5 & 9.49 & $\mathrm{X}$ & & & & & & $X$ & & $X$ & $\mathrm{X}$ & & & & & & $\mathrm{X}$ \\
\hline Thailand & 0.32 & 15 & 3 & 6.66 & & & $\mathrm{X}$ & $X$ & $\mathrm{X}$ & & & & & & & & & & & \\
\hline Turkey & 0.32 & 15 & 4 & 5.83 & & & & & & & $\mathrm{X}$ & $\mathrm{X}$ & & $\mathrm{X}$ & $\mathrm{X}$ & & & & & \\
\hline Uruguay & 0.14 & 15 & 0 & 0.00 & & & & & & & & & & & & & & & & \\
\hline Venezuela & 0.17 & 16 & 1 & 1.82 & & & & & & & $\mathrm{X}$ & & & & & & & & & \\
\hline Chile & 0.25 & 16 & 2 & 3.58 & & & & $\mathrm{X}$ & & & $\mathrm{X}$ & & & & & & & & & \\
\hline India & 0.32 & 15 & 4 & 5.94 & & & & $\mathrm{X}$ & & $X$ & & $\mathrm{X}$ & & $\mathrm{X}$ & & & & & & \\
\hline Pakistan & 0.51 & 15 & 6 & 10.94 & $\mathrm{X}$ & & & $\mathrm{X}$ & & $\mathrm{X}$ & & $\mathrm{X}$ & $X$ & & & & & & & $\mathrm{X}$ \\
\hline Sri Lanka & 0.14 & 14 & 0 & 0.00 & & & & & & & & & & & & & & & & \\
\hline Singapore & 0.14 & 15 & 0 & 0.00 & & & & & & & & & & & & & & & & \\
\hline
\end{tabular}

Source: Author's calculations. 


\begin{tabular}{|c|c|c|c|c|c|c|}
\hline \multicolumn{7}{|c|}{ Table 11: Results from Benchmark Model: The Case of Mexico } \\
\hline & \multicolumn{4}{|c|}{ Number of Signals in Preceding 24 Months } & \multicolumn{2}{|c|}{ Aggregate Information } \\
\hline & September 1976 & February 1982 & December 1982 & December 1994 & Threshold & Noise-to-Signal \\
\hline Reserves & 0 & 0 & 8 & 1 & -49.5 & 0.86 \\
\hline Exports & 4 & 2 & 2 & 0 & -6.5 & 1.02 \\
\hline Real Exchange Rate & 8 & 13 & 0 & 9 & -23.8 & 0 \\
\hline Equity Prices & NA & NA & NA & 8 & 0.15 & 0.26 \\
\hline Commercial Bank Deposits & 0 & 0 & 0 & 1 & 11.5 & 10.9 \\
\hline Output Index & 2 & 0 & 5 & 1 & -2.3 & 1.4 \\
\hline Excess M1 Real Balances & $\mathrm{NA}$ & NA & 0 & 13 & 362.3 & 0.19 \\
\hline M2 Multiplier & 0 & 0 & 0 & 0 & 25.1 & $\mathrm{NA}$ \\
\hline Change in M2/Reserves & 0 & 0 & 5 & 1 & 54.2 & 1.5 \\
\hline Domestic Credit Gap & 0 & 0 & 5 & 1 & 13.1 & 3.4 \\
\hline Real Interest Rate & NA & NA & 0 & 0 & 54.7 & NA \\
\hline Real Interest Rate Diff & $\mathrm{NA}$ & NA & 0 & 0 & 75.4 & NA \\
\hline Imports & 1 & 11 & 0 & 0 & 47.3 & 0.55 \\
\hline US Growth & 9 & 4 & 10 & 0 & -1.2 & 0.10 \\
\hline US Interest Rates & 0 & 8 & 0 & 0 & 2.69 & 1.0 \\
\hline Level M2/Reserves & 0 & 19 & 8 & 0 & 18.4 & 0.1 \\
\hline G-7 Growth & 11 & 7 & 10 & 0 & .25 & 0.02 \\
\hline Oil prices & 3 & 1 & 0 & 0 & 50.1 & 2.5 \\
\hline Level STD/Reserves & NA & NA & NA & 1 & 3.3 & 1.9 \\
\hline Change in STD/Reserves & $\mathrm{NA}$ & NA & $\mathrm{NA}$ & 1 & 73.2 & 1.9 \\
\hline
\end{tabular}

Notes: Table reports the results for Mexico based on the model reported in Table 6. Threshold and noise-to-signal ratios are based on aggregate model, but are country specific.

Source: Author's calculations. 


\begin{tabular}{|l|c|c|c|c|c|c|}
\hline \multicolumn{3}{|c|}{ Table 12: Mexico: An Alternative Method } \\
\hline Variable/Category & $\begin{array}{l}\text { Number } \\
\text { of Signals }\end{array}$ & Threshold & $\begin{array}{c}\text { September } \\
\mathbf{1 9 7 6}\end{array}$ & $\begin{array}{c}\text { February } \\
\mathbf{1 9 8 2}\end{array}$ & $\begin{array}{c}\text { December } \\
\mathbf{1 9 8 2}\end{array}$ & $\begin{array}{c}\text { December } \\
\mathbf{1 9 9 4}\end{array}$ \\
\hline Reserves & 23 & -59 & 0 & 6 & 6 & 1 \\
\hline Exports & 18 & -13.8 & 4 & 1 & 3 & 0 \\
\hline Real Exchange Rate & 10 & -27 & 6 & 0 & 2 & 2 \\
\hline Equity Prices & 5 & -36.7 & na & na & na & 0 \\
\hline Commercial Bank Deposits & 9 & -13.7 & 0 & 0 & 0 & 0 \\
\hline Output Index & 30 & -5.5 & 0 & 0 & 0 & 0 \\
\hline M2 Multiplier & 16 & 38.7 & 0 & 0 & 0 & 0 \\
\hline M2/Reserves & 20 & 65.9 & 0 & 0 & 0 & 0 \\
\hline Domestic Credit/GDP & 17 & 31.9 & 0 & 0 & 0 & 0 \\
\hline Real Interest Rate & 21 & 67.0 & na & 0 & 0 & 0 \\
\hline Real Interest Differential & 21 & 60.0 & na & 0 & & 0 \\
\hline Imports & 21 & 21 & 5 & 1 & & 0 \\
\hline
\end{tabular}

Notes: Model is a simplified version of the standard signals approach. The threshold is simply defined as the mean of the indicator plus (minus) 1.5 of its standard deviations.

Source: Author's calculations. 


\begin{tabular}{|c|c|c|c|c|c|c|}
\hline \multicolumn{7}{|c|}{$\begin{array}{c}\text { Table 13 } \\
\text { Robustness Test 1: Summary Results } \\
\text { Regional Differences using Benchmark model January } 1970 \text { - December } 1995^{1}\end{array}$} \\
\hline \multirow[b]{2}{*}{ Variable $^{2}$} & \multicolumn{3}{|c|}{ Latin American Region } & \multicolumn{3}{|c|}{ Asian Region } \\
\hline & Number of Crises ${ }^{3}$ & Noise-to-Signal Ratio ${ }^{4}$ & Share of Crises Called & Number of Crises ${ }^{3}$ & Noise-to-Signal Ratio ${ }^{4}$ & Share of Crises Called \\
\hline Reserves & 28 & 0.43 & 0.79 & 24 & 0.57 & 0.58 \\
\hline Exports & 28 & 0.45 & 0.93 & 24 & 0.81 & 0.50 \\
\hline Commercial Bank Deposit & 28 & 0.92 & 0.46 & 24 & 1.08 & 0.50 \\
\hline Output Index & 18 & 0.58 & 0.72 & 13 & 0.75 & 0.38 \\
\hline Excess real M1 balances & 20 & 0.47 & 0.50 & 14 & 1.39 & 0.50 \\
\hline M2 Multiplier & 28 & 1.14 & 0.46 & 24 & 0.89 & 0.83 \\
\hline M2/Reserves & 28 & 0.43 & 0.71 & 24 & 0.51 & 0.50 \\
\hline Domestic Credit - GDP ratio & 26 & 0.61 & 0.58 & 24 & 1.01 & 0.63 \\
\hline Imports & 28 & 1.0 & 0.46 & 24 & 0.69 & 0.54 \\
\hline US Growth Rate & 28 & 0.46 & 0.46 & 24 & 0.99 & 0.38 \\
\hline G7 Growth & 28 & 0.38 & 0.43 & 24 & 1.13 & 0.25 \\
\hline Change in US Interest Rate & 28 & 1.03 & 0.39 & 24 & 0.71 & 0.33 \\
\hline Change in Oil Prices & 28 & 1.23 & 0.50 & 24 & 0.62 & 0.29 \\
\hline Level of M2/Reserves & 28 & 0.26 & 0.61 & 25 & 0.57 & 0.44 \\
\hline Change in STD/Reserves & 8 & 0.39 & 0.88 & 3 & 0.34 & 1.0 \\
\hline Level of STD/Reserves & 9 & 0.41 & 0.67 & 4 & 0.43 & 0.50 \\
\hline
\end{tabular}

Notes: Estimation period January 1970 to April 1995 for Latin American Region (Argentina, Bolivia, Brazil, Colombia, Mexico, Peru, Uruguay, Venezuela, and Chile) and Asian Region (Indonesia, Korea, Malaysia, Philippines, Thailand, India, Pakistan, Sri Lanka, and Singapore) 2. Variables are measured as 12-month percentage changes, except interest rates, real exchange rate (deviation from trend), and excess M1(residual from M1 equation). 3. Number of crises for which data exist for this variable. 4. Ratio of false signals to total number of months there is no crisis relative to proportion of good signals $[\mathrm{B} /(\mathrm{B}+\mathrm{D})] /[\mathrm{A} /(\mathrm{A}+\mathrm{C})]$.

Source: Author's calculations. 


\begin{tabular}{|c|c|c|c|c|c|c|}
\hline \multicolumn{7}{|c|}{$\begin{array}{c}\text { Table } 14 \text { Robustness Test } 2 \\
\text { Frankel-Rose Crisis Dating January } 1970 \text { - December } 1995^{1}\end{array}$} \\
\hline Variable $^{2}$ & Number of Crises ${ }^{3}$ & Number of Countries & Size of critical region ${ }^{4}$ & Noise-to-signal ratio ${ }^{5}$ & Probability of Crisis ${ }^{6}$ & Share of crises called ${ }^{7}$ \\
\hline Reserves $^{1}$ & 76 & 23 & 0.10 & 0.55 & 0.38 & 0.63 \\
\hline Exports $^{1}$ & 75 & 23 & 0.10 & 0.48 & 0.42 & 0.84 \\
\hline Real Exchange Rates $^{1}$ & 76 & 23 & 0.10 & 0.26 & 0.56 & 0.45 \\
\hline Index of Equity Prices ${ }^{1}$ & 35 & 15 & 0.14 & 0.39 & 0.34 & 0.69 \\
\hline Commercial Bank Deposit ${ }^{1}$ & 70 & 20 & 0.12 & 0.92 & 0.28 & 0.39 \\
\hline Output Index ${ }^{1}$ & 56 & 19 & 0.10 & 0.56 & 0.36 & 0.50 \\
\hline Excess real M1 balances $^{2}$ & 45 & 19 & 0.10 & 0.58 & 0.31 & 0.49 \\
\hline M2 Multiplier ${ }^{2}$ & 74 & 23 & 0.15 & 0.88 & 0.28 & 0.59 \\
\hline M2/Reserves ${ }^{2}$ & 74 & 23 & 0.10 & 0.55 & 0.39 & 0.61 \\
\hline Domestic Credit Gap $^{2}$ & 64 & 20 & 0.10 & 0.65 & 0.34 & 0.50 \\
\hline Real Interest Rate $^{2}$ & 48 & 18 & 0.20 & 1.02 & 0.20 & 0.35 \\
\hline Real Interest Diff. ${ }^{2}$ & 47 & 18 & 0.20 & 1.37 & 0.16 & 0.32 \\
\hline Lending/Deposit Ratio ${ }^{2}$ & 30 & 14 & 0.12 & 0.91 & 0.16 & 0.30 \\
\hline Imports $^{2}$ & 76 & 23 & 0.10 & 0.97 & 0.26 & 0.54 \\
\hline US Growth Rate & 76 & 23 & 0.10 & 0.60 & 0.37 & 0.53 \\
\hline G7 Growth & 76 & 23 & 0.12 & 0.52 & 0.40 & 0.45 \\
\hline Change in US Interest Rate & 76 & 23 & 0.10 & 0.85 & 0.29 & 0.39 \\
\hline Change in Oil Prices & 76 & 23 & 0.10 & 1.01 & 0.25 & 0.37 \\
\hline Level of M2/Reserves & 75 & 23 & 0.12 & 0.64 & 0.35 & 0.43 \\
\hline Change in STD/Reserves & 15 & 8 & 0.20 & 0.52 & 0.16 & 0.93 \\
\hline Level of STD/Reserves & 18 & 10 & 0.15 & 0.61 & 0.16 & 0.44 \\
\hline
\end{tabular}

Notes: Estimation period January 1970 to April 1995 for 23 countries (Argentina, Bolivia, Brazil, Colombia, Denmark, Finland, Indonesia, Israel, Korea, Malaysia, Mexico, Peru, Philippines, Portugal, South Africa, Spain, Sweden, Thailand, Turkey, Uruguay, Venezuela, Chile, Norway, Greece, India, Pakistan, Sri Lanka, and Singapore). 2. Variables are measured as 12-month percentage changes, except interest rates, real exchange rate (deviation from trend), and excess M1. 3. Number of crises for which data exist for this variable. 4. Optimal threshold 5. Ratio of false signals to total number of months there is no crisis relative to proportion of good signals $[\mathrm{B} /(\mathrm{B}+\mathrm{D})] /[\mathrm{A} /(\mathrm{A}+\mathrm{C})]$. 6. Probability of a crisis $\mathrm{A} /(\mathrm{A}+\mathrm{B})$. 7. Defined as the number of crises for which indicator issued at least one signal during the twenty-four months prior to the crisis.

Source: Author's calculations. 
Figure 1

Identification of Currency Crises: Exchange Rate Pressure Index and Crisis Threshold

Mexico

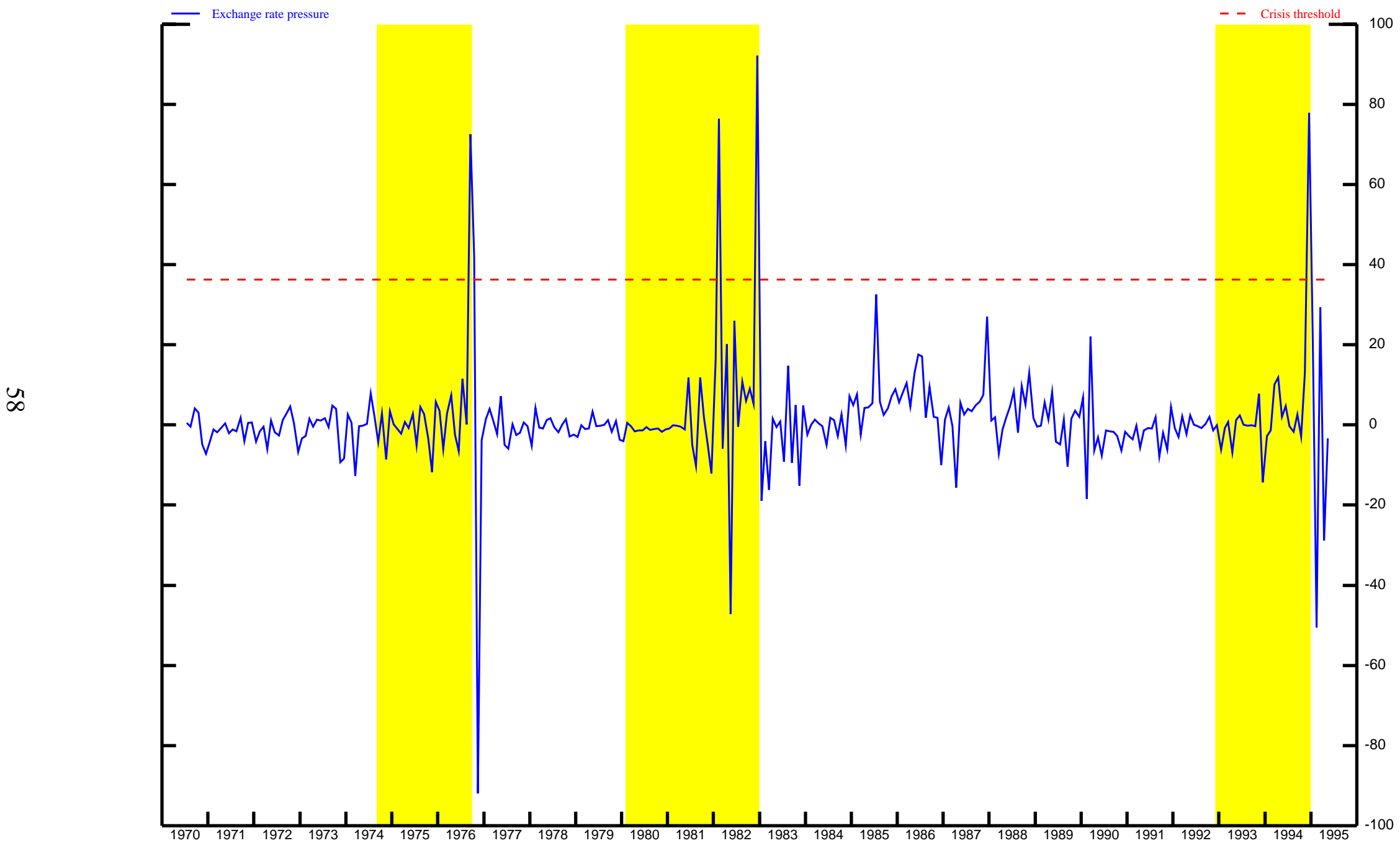

Note: Solid line represents the exchange rate pressure variable, calculated as the weighted average of percent changes in the exchange rate and percent changes in foreign reserves. The dashed line is Source: Author's calculation. 
Figure 2

Identification of Crises: Exchange Rate Pressure Index and Crisis Threshold
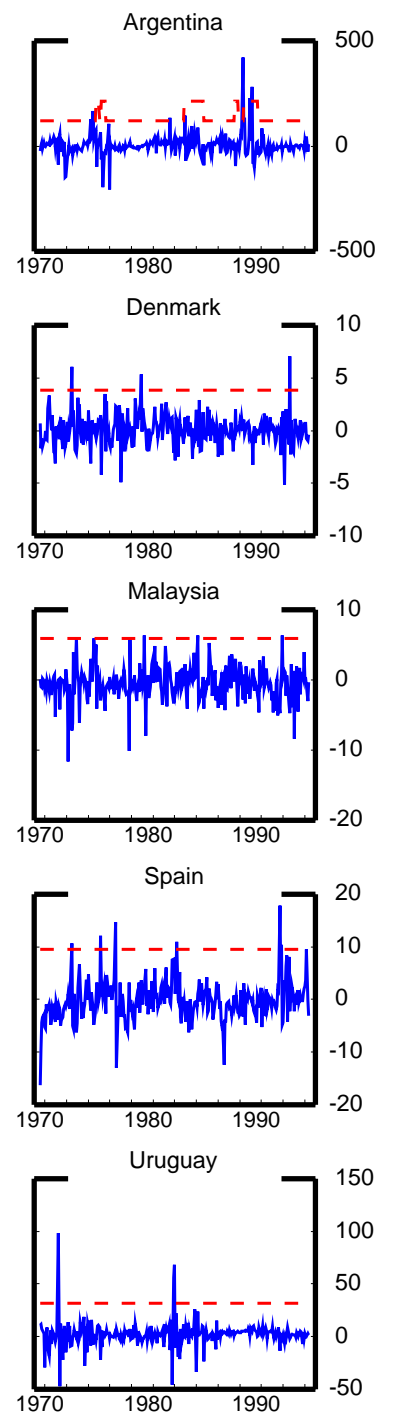
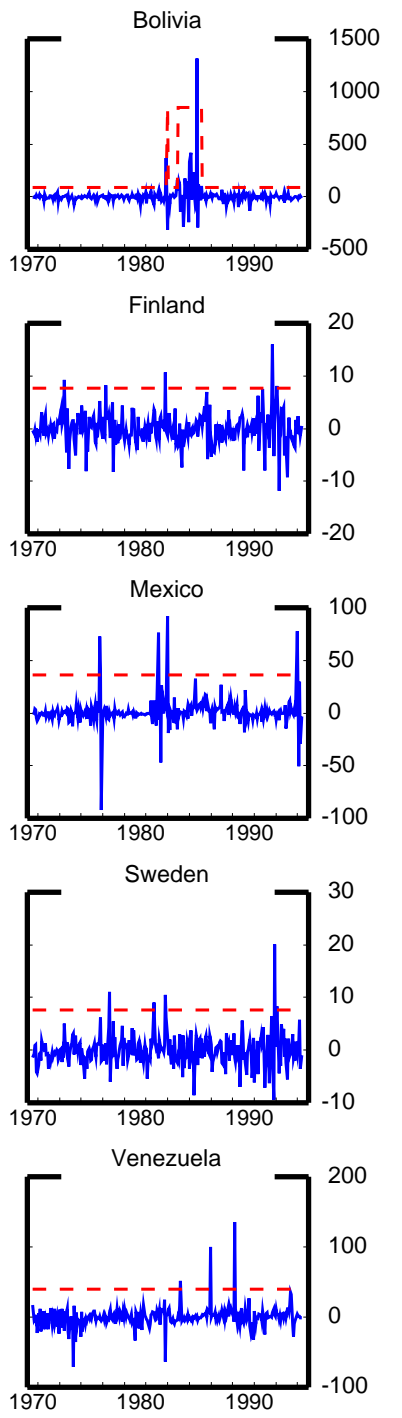
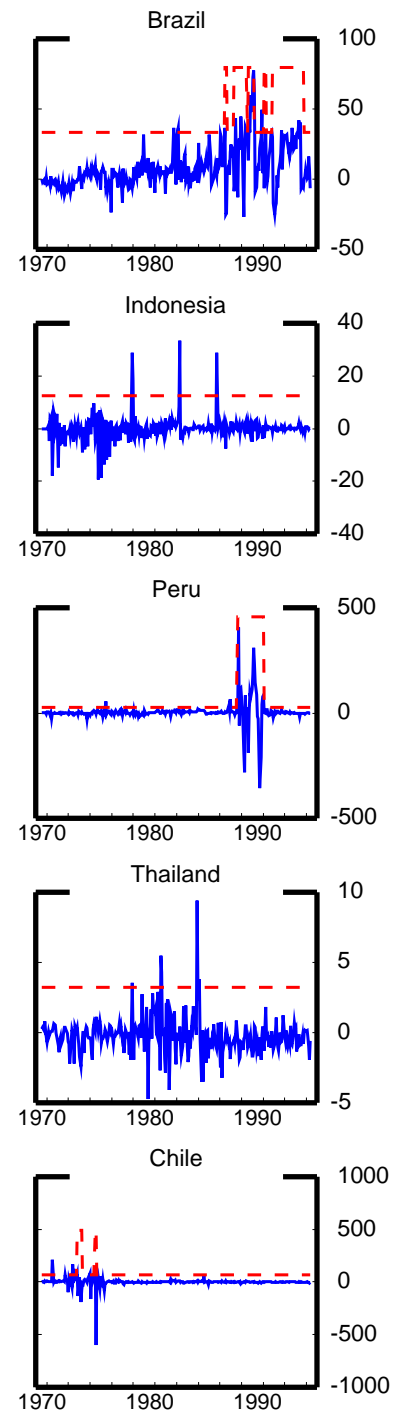
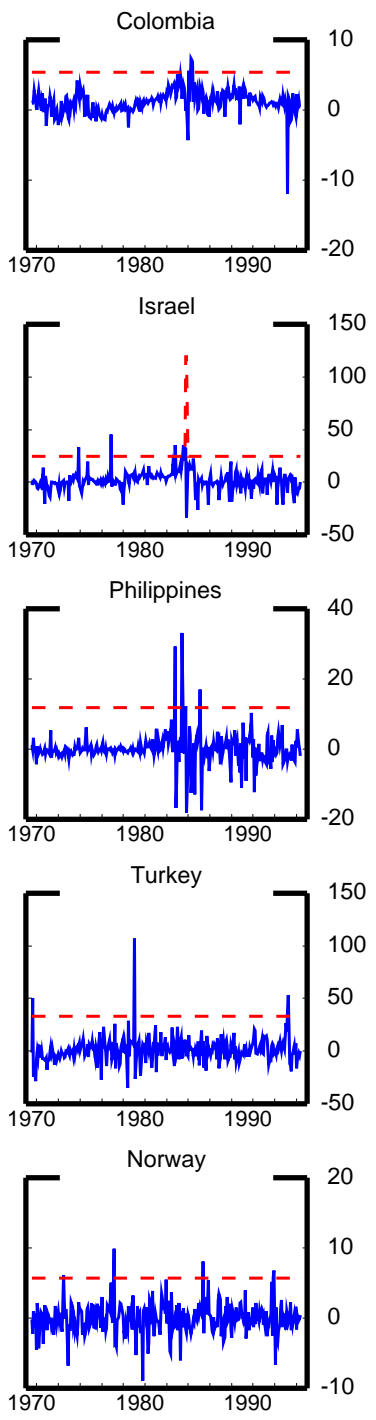

Note: Solid line represents the exchange rate pressure variable, calculated as the weighted average of percent changes in the exchange rate and percent changes in foreign reserves. The dashed line is the threshold above which the exchange rate pressure indicales a cirbis, Calcullaed as hie mean of Source: Author's calculation. 
Figure 3

\section{Performance of the Indicators}

\section{Signal-to-Noise Ratio*}

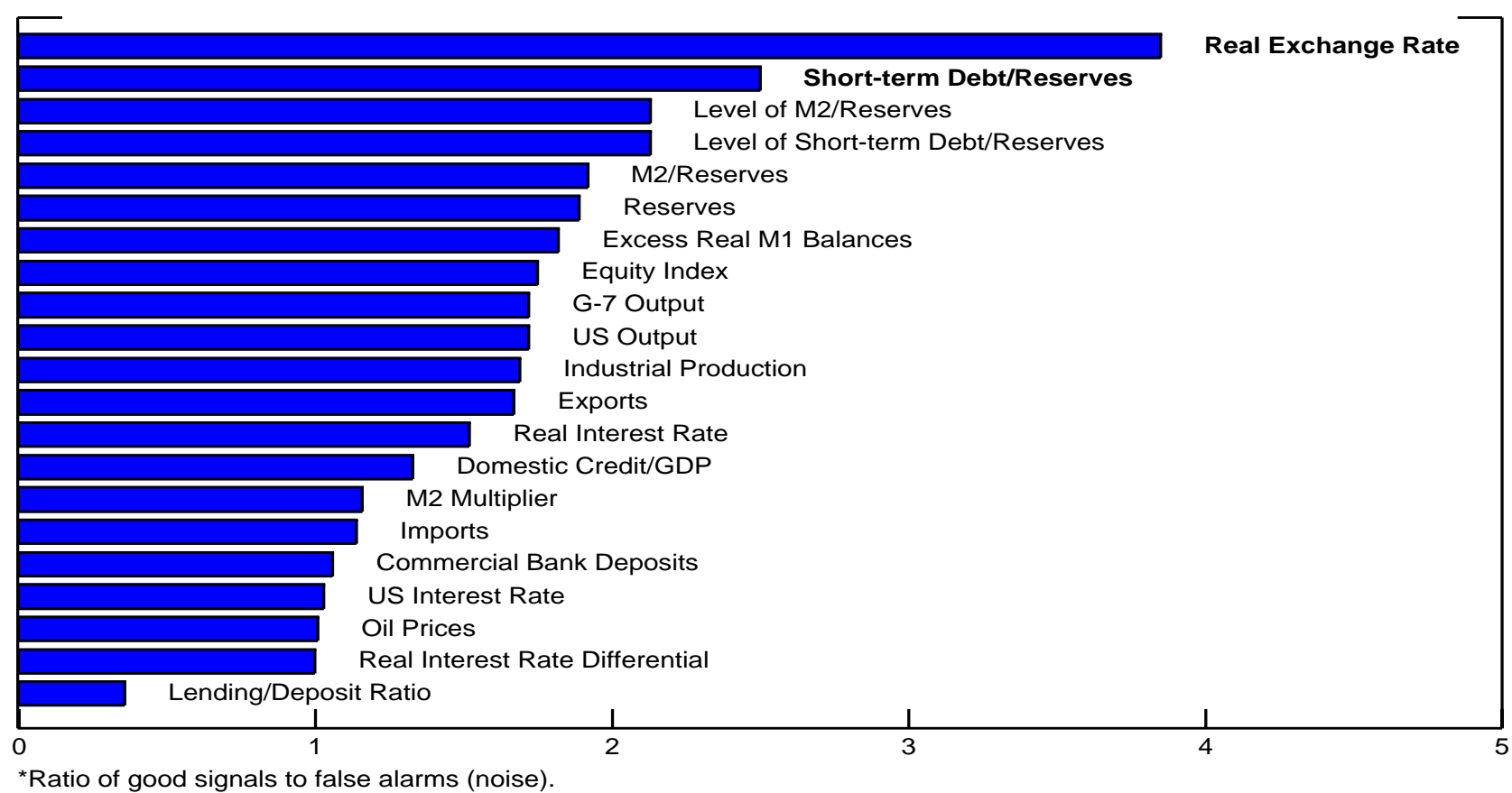

\section{Share of Crises Called Correctly* (ordered as above)}

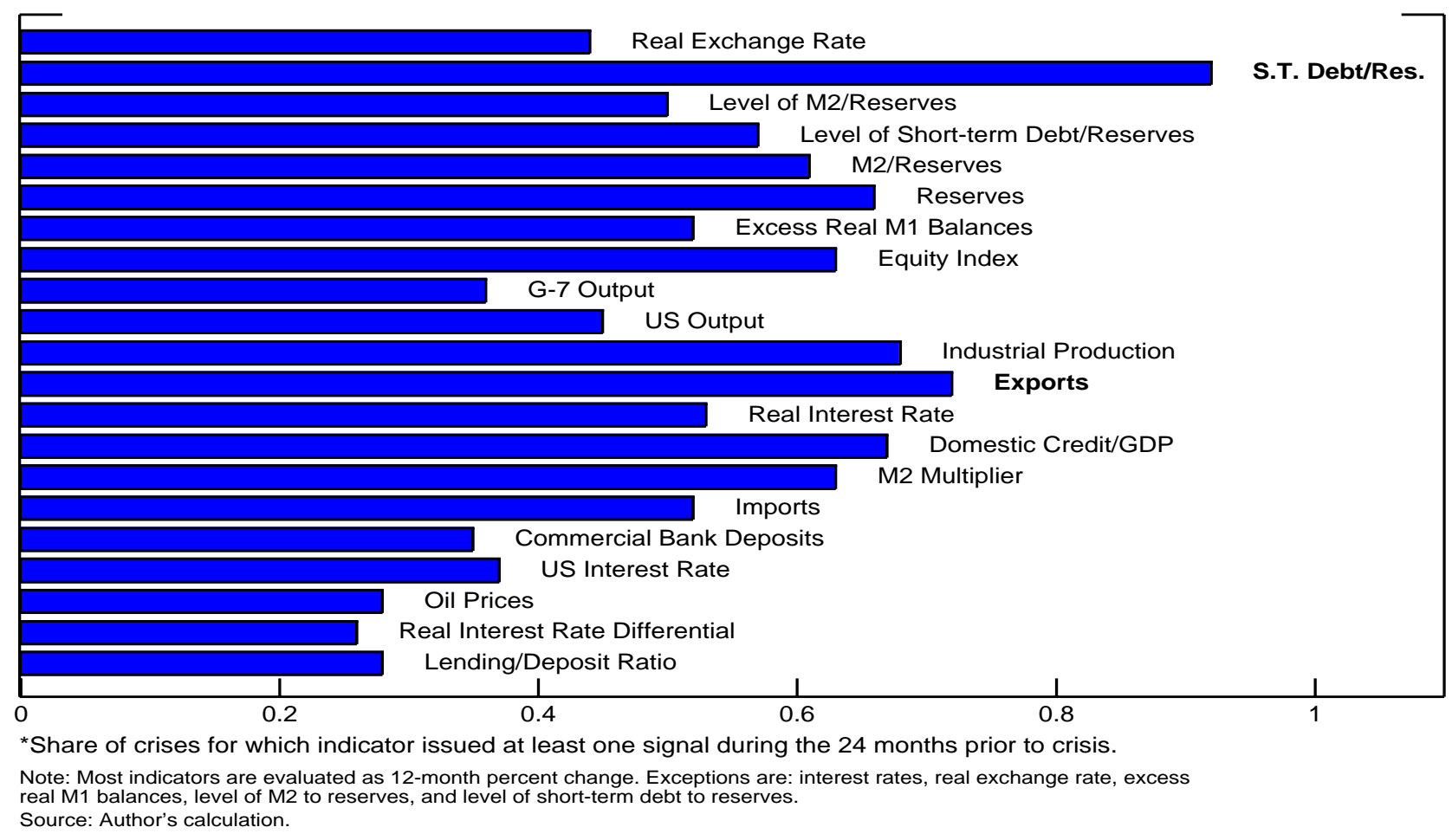


Figure 4

\section{Out-of-Sample Performance}

Estimated Probability of Crises as of Given Date

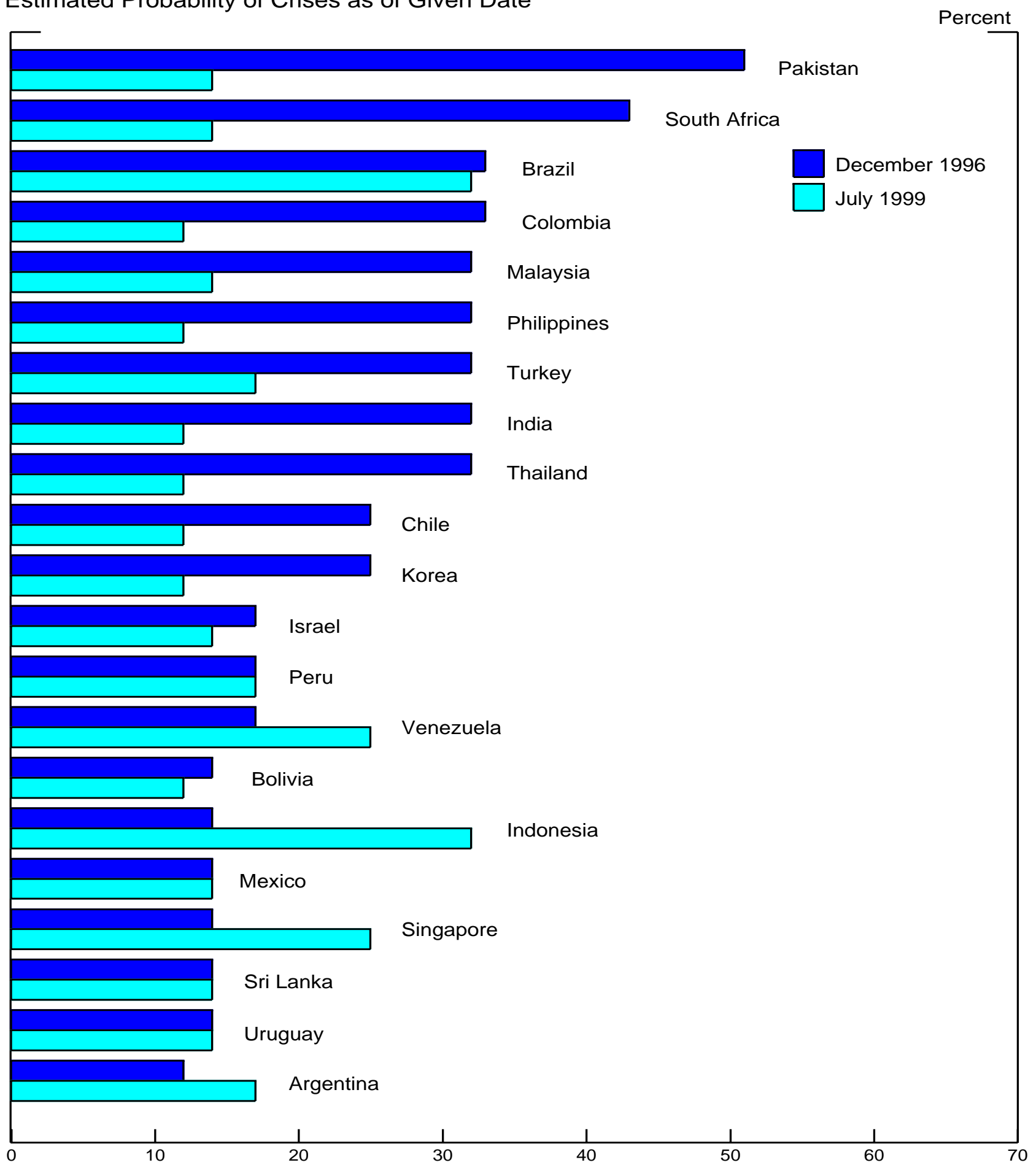

Source: Author's calculation. 
Figure 5

\section{Crisis Probabilities Overtime for Selected Countries}

Argentina

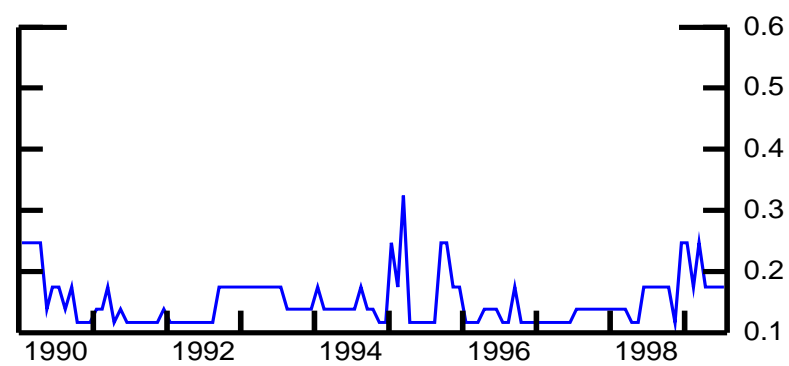

Brazil

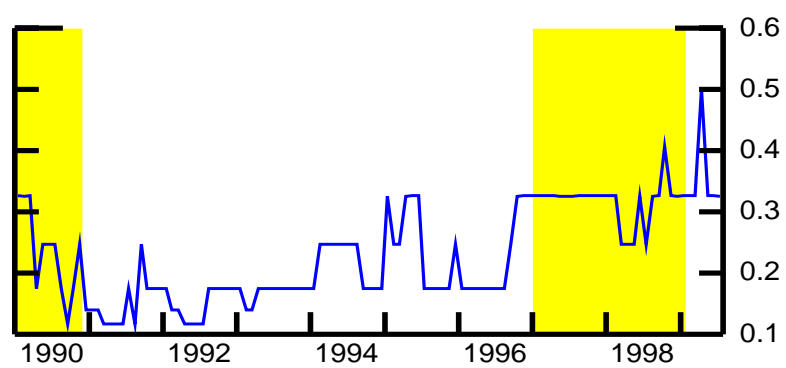

Mexico

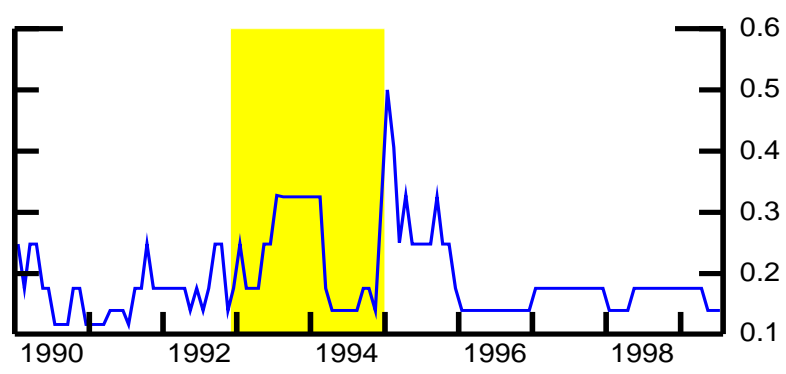

Indonesia

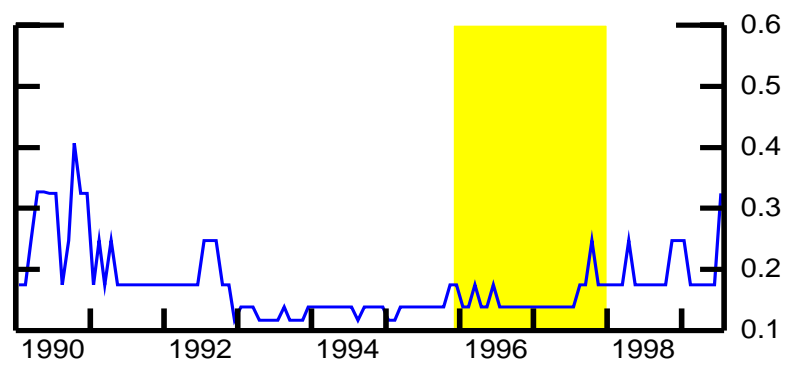

Korea

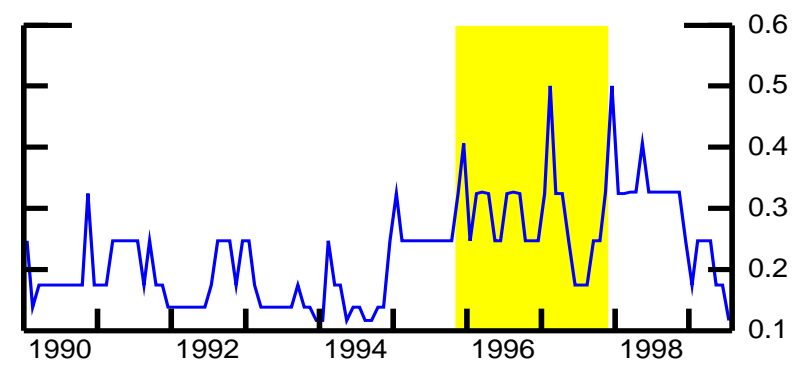

Malaysia

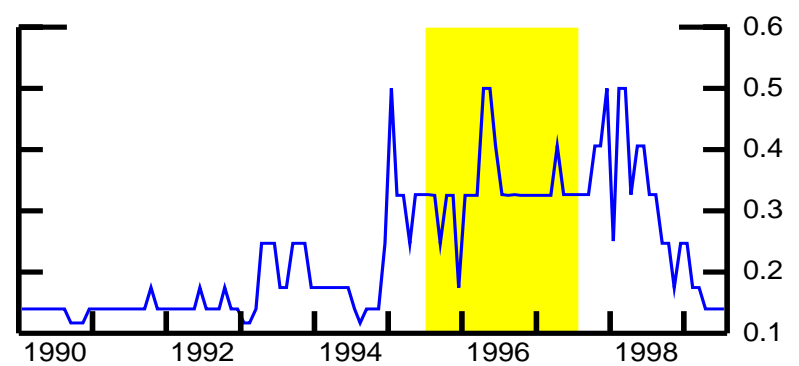

Philippines

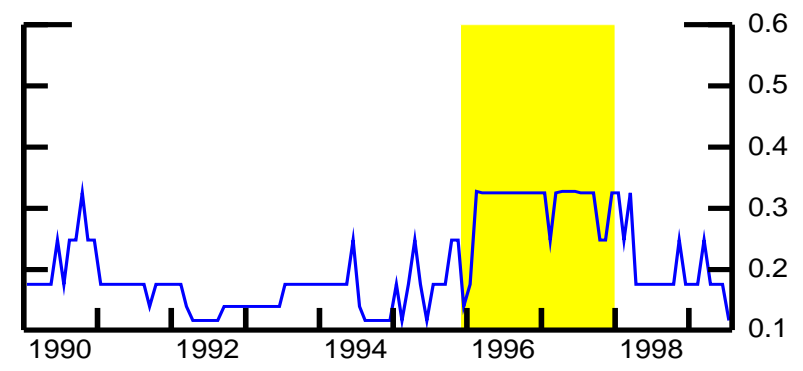

Thailand

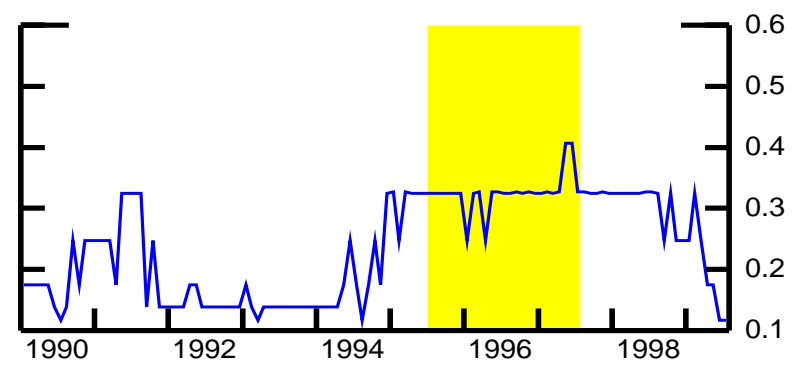

Source: Author's calculation. 
Figure 6

\section{Illustrative Application: Mexico}

Indicators of Vulnerability

Real Exchange Rate $(\$ /$ Peso)

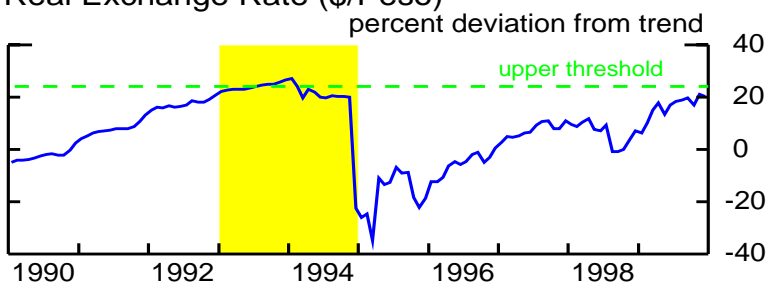

M2/Reserves

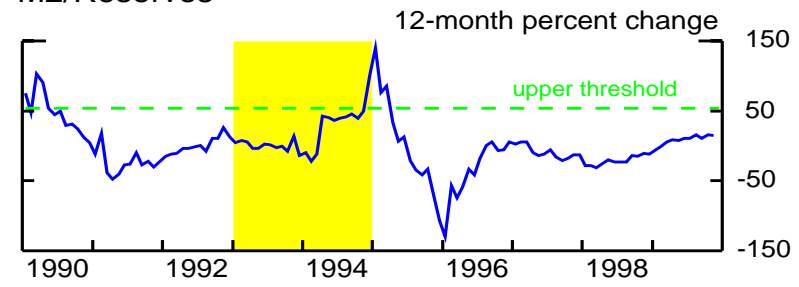

Equity Index

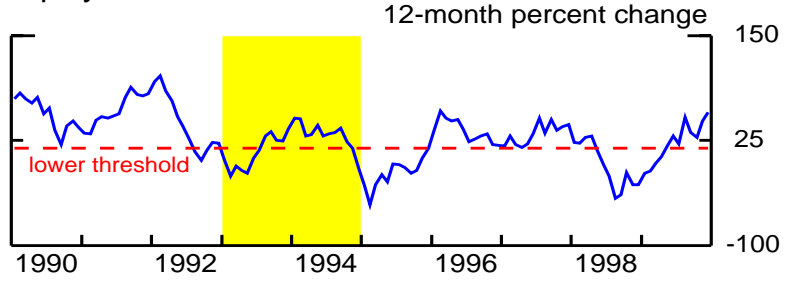

Reserves

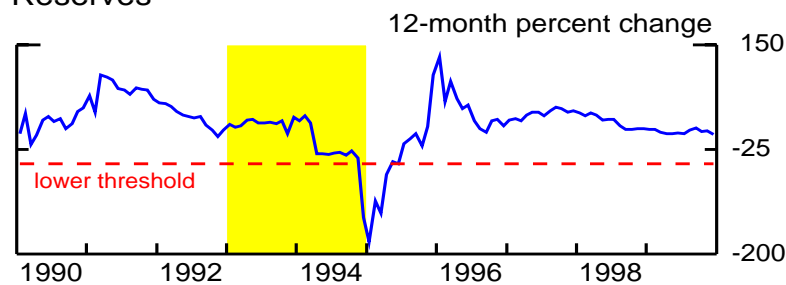

Short-Term Debt*/Reserves

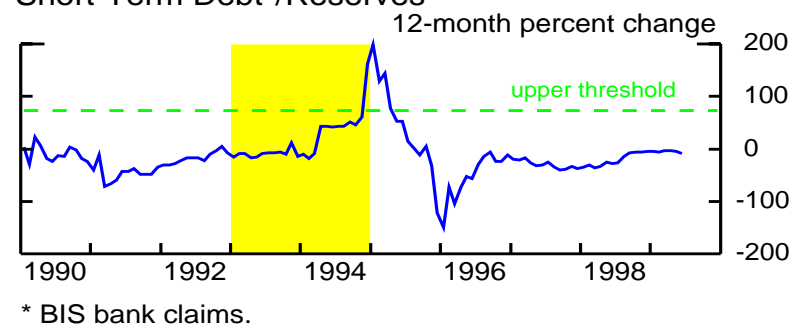

Excess Money Balances*

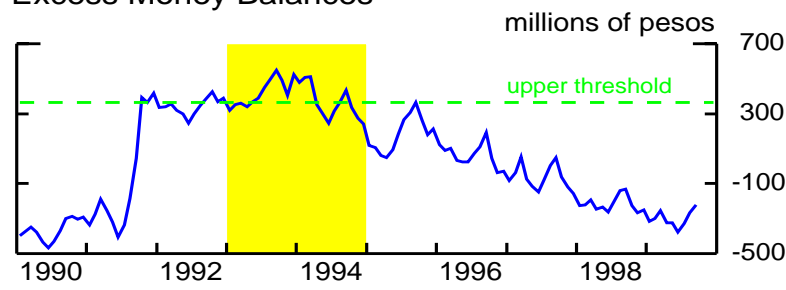

* Based on estimated money demand equation.

\section{4-month-ahead Probability of a Crisis}

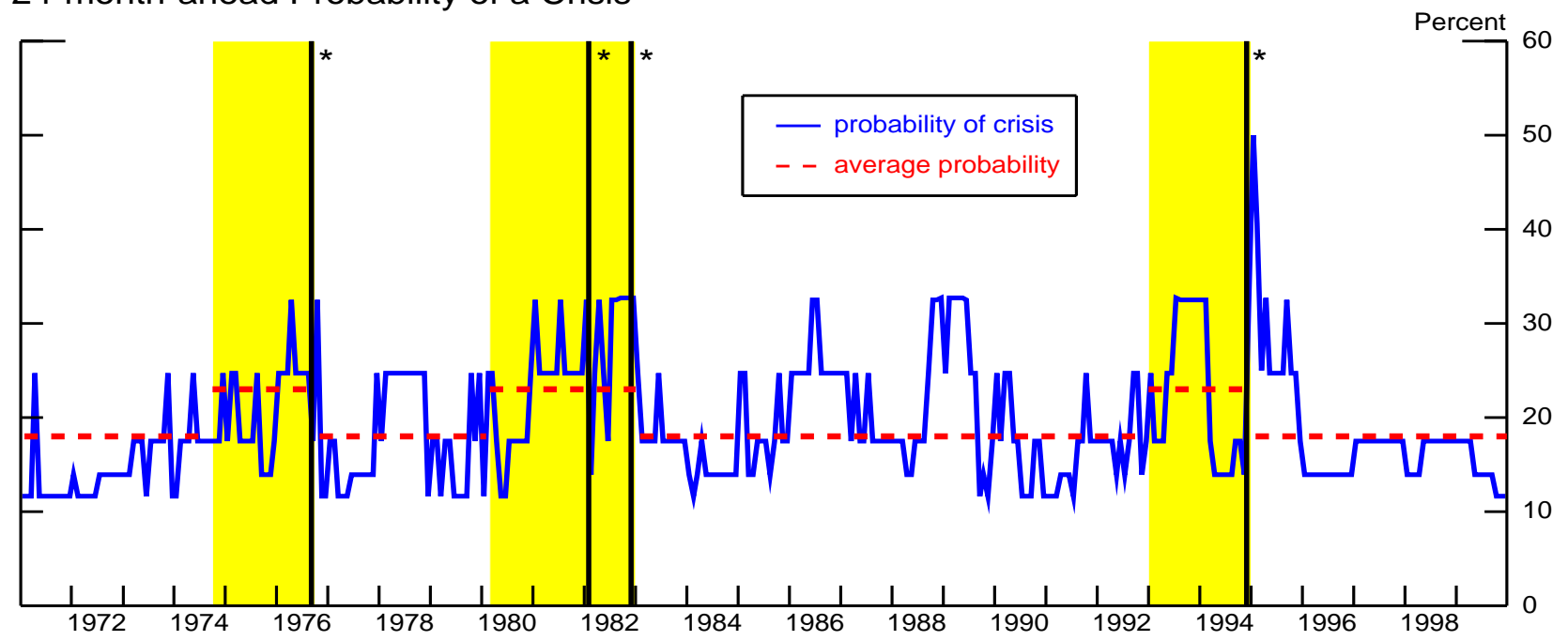

*Identified crisis dates: September 1976, February 1982, December 1982, December 1994.

Source: Author's calculation. 
Figure 7

\section{Mexico: Data Analysis}
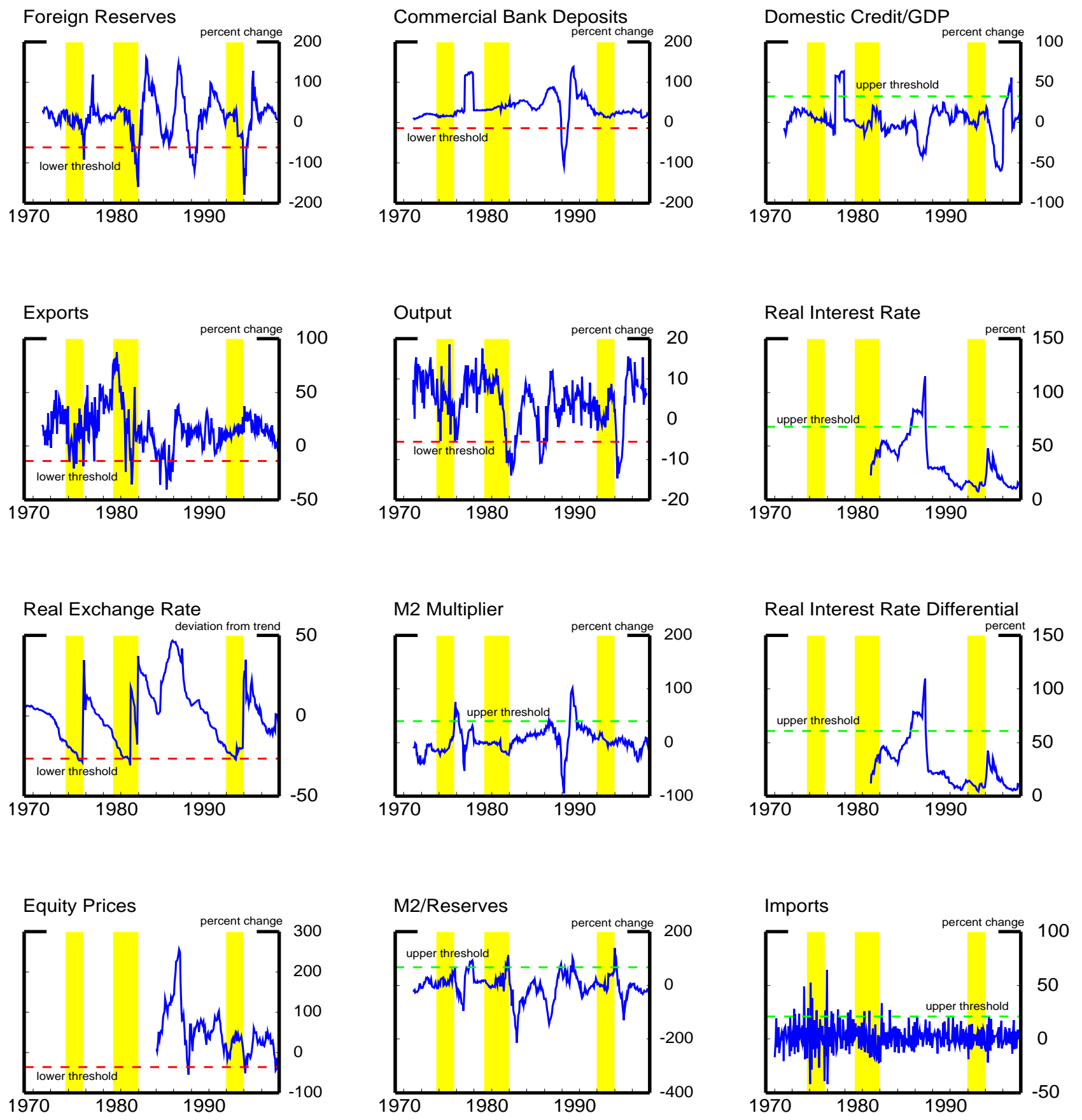

Note: Thresholds are defined as mean of indicator plus (minus) 1.5 of its standard deviation.

Source: Author's calculation. 


\begin{tabular}{|c|c|c|c|c|c|c|c|c|c|c|c|c|c|c|c|}
\hline & & & & Apper & x Table A & Detail Results & the Benc & lark Model & & & & & & & \\
\hline \multirow[t]{2}{*}{ Country } & $\begin{array}{l}\text { Crisis } \\
\text { Dates }\end{array}$ & Reserves & Exports & $\begin{array}{l}\text { Real } \\
\text { Exchange } \\
\text { Rates }\end{array}$ & $\begin{array}{l}\text { Index of } \\
\text { Equity } \\
\text { Prices }\end{array}$ & $\begin{array}{l}\text { Commercial } \\
\text { Bank } \\
\text { Deposits }\end{array}$ & $\begin{array}{l}\text { Output } \\
\text { Index }\end{array}$ & $\begin{array}{l}\text { Excess } \\
\text { M1 } \\
\text { Balances }\end{array}$ & M2 Mult. & $\begin{array}{l}\text { M2 to } \\
\text { Reserves }^{2}\end{array}$ & $\begin{array}{l}\text { Domestic } \\
\text { credit to } \\
\text { GDP }\end{array}$ & $\begin{array}{l}\text { Real } \\
\text { Interest } \\
\text { Rate }\end{array}$ & $\begin{array}{l}\text { Real Interest } \\
\text { Differential }\end{array}$ & $\begin{array}{l}\text { Lending } \\
\text { /Deposit }\end{array}$ & Imports \\
\hline & & $\mathrm{mv} / \mathrm{sig}$ & $\mathrm{mv} / \mathrm{sig}$ & $\mathrm{mv} / \mathrm{sig}$ & $\mathrm{mv} / \mathrm{sig}$ & $\mathrm{mv} / \mathrm{sig}$ & $\mathrm{mv} / \mathrm{sig}$ & $\mathrm{mv} / \mathrm{sig}$ & $\mathrm{mv} / \mathrm{sig}$ & $\mathrm{mv} / \mathrm{sig}$ & $\mathrm{mv} / \mathrm{sig}$ & $\mathrm{mv} / \mathrm{sig}$ & $\mathrm{mv} / \mathrm{sig}$ & $\mathrm{mv} / \mathrm{sig}$ & $\mathrm{mv} / \mathrm{sig}$ \\
\hline \multirow[t]{4}{*}{ Argentina } & Mar-75 & $0 / 0$ & $0 / 2$ & $0 / 21$ & $24 / 0$ & $0 / 0$ & $24 / 0$ & $24 / 0$ & $0 / 0$ & $0 / 1$ & $0 / 13$ & $24 / 0$ & $24 / 0$ & $24 / 0$ & $0 / 4$ \\
\hline & Jul-82 & $0 / 1$ & $0 / 4$ & $0 / 8$ & $24 / 0$ & $0 / 0$ & $5 / 10$ & $4 / 2$ & $0 / 1$ & $0 / 5$ & $0 / 10$ & $0 / 0$ & $0 / 0$ & $24 / 0$ & $0 / 0$ \\
\hline & Apr-89 & $0 / 4$ & $0 / 1$ & $0 / 0$ & $20 / 0$ & $0 / 0$ & $0 / 3$ & $0 / 0$ & $0 / 4$ & $0 / 5$ & $24 / 0$ & $0 / 11$ & $0 / 4$ & $24 / 0$ & $0 / 0$ \\
\hline & Dec-89 & $0 / 0$ & $0 / 1$ & $0 / 0$ & $0 / 0$ & $0 / 0$ & $0 / 4$ & $0 / 0$ & $0 / 0$ & $0 / 0$ & $8 / 0$ & $0 / 5$ & $0 / 3$ & $8 / 0$ & $0 / 0$ \\
\hline \multirow[t]{3}{*}{ Bolivia } & Nov- 82 & $0 / 6$ & $0 / 2$ & $0 / 17$ & -- & $0 / 0$ & -- & $0 / 1$ & $0 / 0$ & $0 / 4$ & $0 / 2$ & $0 / 7$ & $0 / 0$ & $0 / 0$ & $0 / 2$ \\
\hline & Nov- 83 & $0 / 0$ & $0 / 1$ & $0 / 3$ & -- & $0 / 0$ & -- & $0 / 0$ & $0 / 0$ & $0 / 0$ & $0 / 3$ & $0 / 4$ & $0 / 0$ & $0 / 0$ & $0 / 2$ \\
\hline & Sep-85 & $0 / 1$ & $0 / 5$ & $0 / 10$ & -- & $0 / 0$ & -- & $0 / 1$ & $0 / 0$ & $0 / 4$ & $1 / 0$ & $0 / 12$ & $0 / 11$ & $0 / 3$ & $0 / 4$ \\
\hline \multirow[t]{4}{*}{ Brazil } & Sep-82 & $0 / 2$ & $0 / 4$ & $0 / 0$ & $3 / 10$ & $0 / 0$ & $24 / 0$ & $0 / 0$ & $0 / 0$ & $0 / 0$ & $0 / 0$ & $22 / 0$ & $22 / 0$ & -- & $0 / 0$ \\
\hline & Mar-90 & $0 / 1$ & $0 / 3$ & $0 / 23$ & $0 / 0$ & $0 / 0$ & $24 / 0$ & $0 / 0$ & $0 / 16$ & $0 / 2$ & $0 / 11$ & $0 / 9$ & $0 / 6$ & -- & $0 / 0$ \\
\hline & Nov-90 & $0 / 0$ & $0 / 2$ & $0 / 0$ & $0 / 0$ & $0 / 0$ & $8 / 0$ & $0 / 3$ & $0 / 0$ & $0 / 0$ & $0 / 5$ & $0 / 0$ & $0 / 0$ & -- & $0 / 0$ \\
\hline & Sep-91 & $0 / 0$ & $0 / 2$ & $0 / 0$ & $0 / 0$ & $0 / 0$ & $11 / 0$ & $0 / 0$ & $0 / 6$ & $0 / 0$ & $0 / 0$ & $0 / 1$ & $0 / 0$ & -- & $0 / 0$ \\
\hline Colombia & Jan-85 & $0 / 18$ & $0 / 4$ & $0 / 5$ & $0 / 23$ & $9 / 3$ & $0 / 5$ & $5 / 2$ & $13 / 2$ & $13 / 8$ & $12 / 8$ & $24 / 0$ & $24 / 0$ & $24 / 0$ & $0 / 0$ \\
\hline \multirow[t]{3}{*}{ Denmark } & Jun-73 & $0 / 0$ & $0 / 0$ & $0 / 0$ & $0 / 0$ & $0 / 0$ & $24 / 0$ & $24 / 0$ & $0 / 3$ & $0 / 0$ & $0 / 0$ & $24 / 0$ & $24 / 0$ & $24 / 0$ & $0 / 4$ \\
\hline & Nov-79 & $0 / 0$ & $0 / 0$ & $0 / 0$ & $0 / 1$ & $0 / 2$ & $0 / 3$ & $24 / 0$ & $0 / 3$ & $0 / 0$ & $0 / 0$ & $24 / 0$ & $24 / 0$ & $24 / 0$ & $0 / 1$ \\
\hline & Aug-93 & $0 / 4$ & $0 / 5$ & $0 / 1$ & $0 / 8$ & $0 / 9$ & $0 / 8$ & $0 / 2$ & $0 / 3$ & $0 / 3$ & $0 / 0$ & $0 / 0$ & $0 / 0$ & $0 / 3$ & $0 / 0$ \\
\hline \multirow[t]{4}{*}{ Finland } & Jun-73 & $0 / 1$ & $0 / 0$ & $0 / 0$ & $0 / 0$ & $24 / 0$ & $0 / 0$ & $24 / 0$ & $0 / 3$ & $0 / 1$ & $24 / 0$ & $24 / 0$ & $24 / 0$ & $24 / 0$ & $0 / 0$ \\
\hline & Apr-77 & $0 / 2$ & $0 / 5$ & $0 / 0$ & $0 / 11$ & $24 / 0$ & $0 / 15$ & $24 / 0$ & $0 / 0$ & $0 / 5$ & $24 / 0$ & $24 / 0$ & $24 / 0$ & $24 / 0$ & $0 / 0$ \\
\hline & Oct-82 & $0 / 3$ & $0 / 6$ & $0 / 0$ & $0 / 0$ & $24 / 0$ & $0 / 3$ & $24 / 0$ & $0 / 9$ & $0 / 10$ & $24 / 0$ & $4 / 10$ & $4 / 0$ & $4 / 0$ & $0 / 0$ \\
\hline & Sep-92 & $0 / 4$ & $0 / 8$ & $0 / 11$ & $0 / 18$ & $24 / 0$ & $0 / 16$ & $0 / 8$ & $0 / 14$ & $0 / 2$ & $24 / 0$ & $0 / 0$ & $0 / 0$ & $0 / 0$ & $0 / 0$ \\
\hline & & & & & & & & & & & & & & & \\
\hline & & & & & & & & & & & & & & & \\
\hline
\end{tabular}




\begin{tabular}{|c|c|c|c|c|c|c|c|c|c|c|c|c|c|c|c|}
\hline \multicolumn{16}{|c|}{ Appendix Table A continued } \\
\hline Country & $\begin{array}{l}\text { Crisis } \\
\text { Dates }\end{array}$ & Reserves & Exports & $\begin{array}{l}\text { Real } \\
\text { Exchange } \\
\text { Rates }\end{array}$ & $\begin{array}{l}\text { Index of } \\
\text { Equity } \\
\text { Prices }\end{array}$ & $\begin{array}{l}\text { Commercial } \\
\text { Bank } \\
\text { Deposits }\end{array}$ & $\begin{array}{l}\text { Output } \\
\text { Index }\end{array}$ & $\begin{array}{l}\text { Excess } \\
\text { M1 } \\
\text { Balances }\end{array}$ & M2 Mult. & $\begin{array}{l}\text { M2 to } \\
\text { Reserves }^{2}\end{array}$ & $\begin{array}{l}\text { Domestic } \\
\text { credit to } \\
\text { GDP }\end{array}$ & $\begin{array}{l}\text { Real } \\
\text { Interest } \\
\text { Rate }\end{array}$ & $\begin{array}{l}\text { Real Interest } \\
\text { Differential }\end{array}$ & $\begin{array}{l}\text { Lending } \\
\text { /Deposit }\end{array}$ & Imports \\
\hline & & $\mathrm{mv} / \mathrm{sig}$ & $\mathrm{mv} / \mathrm{sig}$ & $\mathrm{mv} / \mathrm{sig}$ & $\mathrm{mv} / \mathrm{sig}$ & $\mathrm{mv} / \mathrm{sig}$ & $\mathrm{mv} / \mathrm{sig}$ & $\mathrm{mv} / \mathrm{sig}$ & $\mathrm{mv} / \mathrm{sig}$ & $\mathrm{mv} / \mathrm{sig}$ & $\mathrm{mv} / \mathrm{sig}$ & $\mathrm{mv} / \mathrm{sig}$ & $\mathrm{mv} / \mathrm{sig}$ & $\mathrm{mv} / \mathrm{sig}$ & $\mathrm{mv} / \mathrm{sig}$ \\
\hline \multirow[t]{3}{*}{ Indonesia } & Nov-78 & $0 / 0$ & $0 / 2$ & $0 / 23$ & $24 / 0$ & $0 / 10$ & $0 / 0$ & $24 / 0$ & $0 / 2$ & $0 / 0$ & $0 / 7$ & $0 / 0$ & $0 / 0$ & $24 / 0$ & $0 / 1$ \\
\hline & Apr-83 & $0 / 13$ & $0 / 6$ & $0 / 1$ & $24 / 0$ & $0 / 3$ & $0 / 15$ & $24 / 0$ & $0 / 1$ & $0 / 13$ & $0 / 13$ & $0 / 0$ & $0 / 0$ & $24 / 0$ & $0 / 3$ \\
\hline & Sep-86 & $0 / 0$ & $0 / 10$ & $0 / 0$ & $24 / 0$ & $0 / 2$ & $0 / 6$ & $0 / 0$ & $0 / 1$ & $0 / 0$ & $0 / 2$ & $4 / 8$ & $4 / 0$ & $19 / 3$ & $0 / 0$ \\
\hline \multirow[t]{4}{*}{ Israel } & Nov-74 & $0 / 4$ & $0 / 1$ & $0 / 12$ & $0 / 15$ & $0 / 13$ & $0 / 4$ & $24 / 0$ & $0 / 3$ & $0 / 3$ & $0 / 13$ & $24 / 0$ & $24 / 0$ & $24 / 0$ & $0 / 17$ \\
\hline & Nov-77 & $0 / 5$ & $0 / 0$ & $0 / 10$ & $0 / 0$ & $0 / 0$ & $0 / 4$ & $24 / 0$ & $0 / 0$ & $0 / 0$ & $0 / 12$ & $24 / 0$ & $24 / 0$ & $24 / 0$ & $0 / 0$ \\
\hline & Oct- 83 & $0 / 0$ & $0 / 13$ & $0 / 0$ & $0 / 0$ & $0 / 0$ & $0 / 3$ & $24 / 0$ & $0 / 2$ & $0 / 2$ & $0 / 4$ & $24 / 0$ & $24 / 0$ & $24 / 0$ & $0 / 0$ \\
\hline & Jul-84 & $0 / 1$ & $0 / 1$ & $0 / 0$ & $0 / 1$ & $0 / 0$ & $0 / 0$ & $9 / 0$ & $0 / 0$ & $0 / 0$ & $0 / 3$ & $1 / 8$ & $1 / 6$ & $1 / 0$ & $0 / 0$ \\
\hline \multirow[t]{3}{*}{ Korea } & Jun-71 & $18 / 0$ & $18 / 0$ & $6 / 0$ & $24 / 0$ & $18 / 0$ & $18 / 0$ & $24 / 0$ & $18 / 0$ & $18 / 0$ & $18 / 0$ & $7 / 17$ & $7 / 17$ & $24 / 0$ & $18 / 2$ \\
\hline & Dec-74 & $0 / 6$ & $0 / 3$ & $0 / 0$ & $24 / 0$ & $0 / 0$ & $0 / 0$ & $24 / 0$ & $0 / 2$ & $0 / 6$ & $0 / 2$ & $0 / 2$ & $0 / 0$ & $24 / 0$ & $0 / 19$ \\
\hline & Jan-80 & $0 / 0$ & $0 / 0$ & $0 / 20$ & $11 / 8$ & $0 / 0$ & $0 / 4$ & $24 / 0$ & $0 / 1$ & $0 / 4$ & $0 / 7$ & $0 / 22$ & $0 / 4$ & $24 / 0$ & $0 / 5$ \\
\hline \multirow[t]{5}{*}{ Malaysia } & Nov-73 & $0 / 0$ & $0 / 0$ & $0 / 2$ & $24 / 0$ & $0 / 0$ & $1 / 0$ & $0 / 0$ & $0 / 3$ & $0 / 0$ & $0 / 11$ & $24 / 0$ & $24 / 0$ & $24 / 0$ & $0 / 7$ \\
\hline & Nov-78 & $0 / 0$ & $0 / 0$ & $0 / 4$ & $24 / 0$ & $0 / 0$ & $0 / 0$ & $0 / 0$ & $0 / 1$ & $0 / 0$ & $0 / 0$ & $0 / 0$ & $0 / 0$ & $0 / 0$ & $0 / 1$ \\
\hline & Mar-80 & $0 / 0$ & $0 / 0$ & $0 / 8$ & $16 / 0$ & $0 / 0$ & $0 / 0$ & $0 / 6$ & $0 / 5$ & $0 / 0$ & $0 / 0$ & $0 / 0$ & $0 / 0$ & $0 / 0$ & $0 / 6$ \\
\hline & Feb-85 & $0 / 1$ & $0 / 0$ & $0 / 0$ & $24 / 0$ & $0 / 0$ & $0 / 5$ & $0 / 0$ & $0 / 1$ & $0 / 1$ & $0 / 0$ & $0 / 16$ & $0 / 0$ & $0 / 0$ & $0 / 0$ \\
\hline & Dec-92 & $0 / 0$ & $0 / 0$ & $0 / 0$ & $24 / 0$ & $0 / 0$ & $0 / 0$ & $0 / 0$ & $0 / 0$ & $0 / 0$ & $0 / 1$ & $0 / 2$ & $0 / 13$ & $0 / 0$ & $0 / 0$ \\
\hline \multirow[t]{4}{*}{ Mexico } & Sep-76 & $0 / 0$ & $0 / 4$ & $0 / 8$ & $24 / 0$ & $0 / 0$ & $0 / 2$ & $24 / 0$ & $0 / 0$ & $0 / 0$ & $0 / 0$ & $24 / 0$ & $24 / 0$ & -- & $0 / 1$ \\
\hline & Feb-82 & $0 / 0$ & $0 / 2$ & $0 / 13$ & $24 / 0$ & $0 / 0$ & $0 / 0$ & $0 / 0$ & $0 / 0$ & $0 / 0$ & $0 / 0$ & $20 / 0$ & $20 / 0$ & -- & $0 / 11$ \\
\hline & Dec-82 & $0 / 8$ & $0 / 2$ & $0 / 0$ & $10 / 0$ & $0 / 0$ & $0 / 6$ & $0 / 0$ & $0 / 0$ & $0 / 5$ & $0 / 5$ & $0 / 0$ & $0 / 0$ & -- & $0 / 0$ \\
\hline & Dec-94 & $0 / 1$ & $0 / 0$ & $0 / 9$ & $0 / 9$ & $0 / 1$ & $0 / 1$ & $0 / 12$ & $0 / 0$ & $0 / 1$ & $0 / 1$ & $0 / 0$ & $0 / 0$ & -- & $0 / 0$ \\
\hline \multirow[t]{2}{*}{ Peru } & Jun-76 & $0 / 7$ & $0 / 9$ & $0 / 5$ & $24 / 0$ & $0 / 9$ & $24 / 0$ & $0 / 22$ & $0 / 6$ & $0 / 6$ & $0 / 3$ & $24 / 0$ & $24 / 0$ & $24 / 0$ & $0 / 6$ \\
\hline & Oct-87 & $0 / 1$ & $0 / 2$ & $0 / 0$ & $24 / 0$ & $0 / 0$ & $0 / 0$ & $0 / 5$ & $0 / 7$ & $0 / 9$ & $0 / 7$ & $24 / 0$ & $24 / 0$ & $24 / 0$ & $0 / 7$ \\
\hline
\end{tabular}




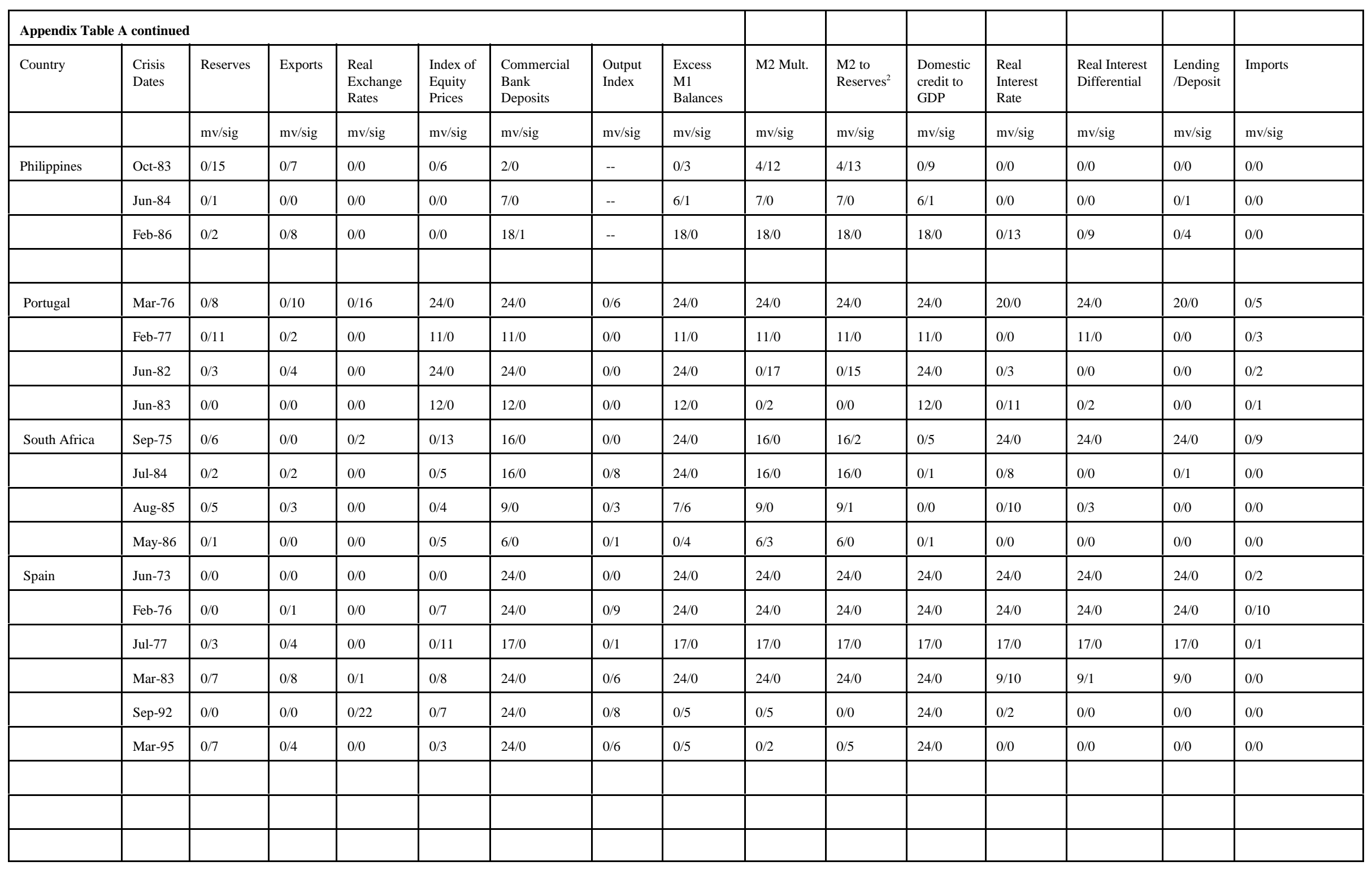




\begin{tabular}{|c|c|c|c|c|c|c|c|c|c|c|c|c|c|c|c|}
\hline \multicolumn{16}{|c|}{ Appendix Table A continued } \\
\hline Country & $\begin{array}{l}\text { Crisis } \\
\text { Dates }\end{array}$ & Reserves & Exports & $\begin{array}{l}\text { Real } \\
\text { Exchange } \\
\text { Rates }\end{array}$ & $\begin{array}{l}\text { Index of } \\
\text { Equity } \\
\text { Prices }\end{array}$ & $\begin{array}{l}\text { Commercial } \\
\text { Bank } \\
\text { Deposits }\end{array}$ & $\begin{array}{l}\text { Output } \\
\text { Index }\end{array}$ & $\begin{array}{l}\text { Excess } \\
\text { M1 } \\
\text { Balances }\end{array}$ & M2 Mult. & $\begin{array}{l}\text { M2 to } \\
\text { Reserves }^{2}\end{array}$ & $\begin{array}{l}\text { Domestic } \\
\text { credit to } \\
\text { GDP }\end{array}$ & $\begin{array}{l}\text { Real } \\
\text { Interest } \\
\text { Rate }\end{array}$ & $\begin{array}{l}\text { Real Interest } \\
\text { Differential }\end{array}$ & $\begin{array}{l}\text { Lending } \\
\text { /Deposit }\end{array}$ & Imports \\
\hline & & $\mathrm{mv} / \mathrm{sig}$ & $\mathrm{mv} / \mathrm{sig}$ & $\mathrm{mv} / \mathrm{sig}$ & $\mathrm{mv} / \mathrm{sig}$ & $\mathrm{mv} / \mathrm{sig}$ & $\mathrm{mv} / \mathrm{sig}$ & $\mathrm{mv} / \mathrm{sig}$ & $\mathrm{mv} / \mathrm{sig}$ & $\mathrm{mv} / \mathrm{sig}$ & $\mathrm{mv} / \mathrm{sig}$ & $\mathrm{mv} / \mathrm{sig}$ & $\mathrm{mv} / \mathrm{sig}$ & $\mathrm{mv} / \mathrm{sig}$ & $\mathrm{mv} / \mathrm{sig}$ \\
\hline \multirow[t]{4}{*}{ Sweden } & Aug-77 & $0 / 6$ & $0 / 2$ & $0 / 0$ & $0 / 6$ & $0 / 0$ & $0 / 9$ & $24 / 0$ & $0 / 11$ & $0 / 6$ & $0 / 0$ & $0 / 0$ & $20 / 0$ & $0 / 2$ & $0 / 3$ \\
\hline & Sep-81 & $0 / 2$ & $0 / 7$ & $0 / 8$ & $0 / 0$ & $0 / 0$ & $0 / 7$ & $24 / 0$ & $0 / 9$ & $0 / 5$ & $0 / 15$ & $0 / 18$ & $0 / 0$ & $0 / 0$ & $0 / 4$ \\
\hline & Oct-82 & $0 / 5$ & $0 / 2$ & $0 / 0$ & $0 / 0$ & $0 / 0$ & $0 / 0$ & $13 / 0$ & $0 / 1$ & $0 / 1$ & $0 / 8$ & $0 / 12$ & $0 / 0$ & $0 / 0$ & $0 / 0$ \\
\hline & Nov-92 & $0 / 1$ & $0 / 3$ & $0 / 22$ & $0 / 18$ & $0 / 9$ & $0 / 9$ & $3 / 3$ & $0 / 12$ & $0 / 1$ & $0 / 0$ & $0 / 1$ & $0 / 0$ & $16 / 6$ & $0 / 0$ \\
\hline \multirow[t]{3}{*}{ Thailand } & Nov-78 & $0 / 0$ & $0 / 1$ & $0 / 1$ & $24 / 0$ & $0 / 0$ & -- & $24 / 0$ & $0 / 4$ & $0 / 0$ & $0 / 1$ & $1 / 0$ & $1 / 0$ & $1 / 3$ & $0 / 0$ \\
\hline & Jul-81 & $0 / 14$ & $0 / 2$ & $0 / 21$ & $24 / 0$ & $0 / 4$ & -- & $16 / 0$ & $0 / 3$ & $0 / 14$ & $0 / 0$ & $0 / 2$ & $0 / 0$ & $0 / 11$ & $0 / 1$ \\
\hline & Nov-84 & $0 / 1$ & $0 / 8$ & $0 / 0$ & $24 / 0$ & $0 / 0$ & -- & $0 / 0$ & $0 / 17$ & $0 / 4$ & $0 / 17$ & $0 / 16$ & $0 / 0$ & $0 / 0$ & $0 / 1$ \\
\hline \multirow[t]{3}{*}{ Turkey } & Aug-70 & $24 / 0$ & $24 / 0$ & $16 / 0$ & -- & $24 / 0$ & $24 / 0$ & $24 / 0$ & $24 / 0$ & $24 / 0$ & $24 / 0$ & $24 / 0$ & $24 / 0$ & -- & $24 / 0$ \\
\hline & Jan-80 & $0 / 0$ & $0 / 3$ & $0 / 20$ & -- & $0 / 11$ & $24 / 0$ & $24 / 0$ & $0 / 0$ & $0 / 2$ & $24 / 0$ & $10 / 0$ & $10 / 0$ & -- & $0 / 2$ \\
\hline & Mar-94 & $0 / 2$ & $0 / 0$ & $0 / 0$ & -- & $0 / 0$ & $0 / 0$ & $0 / 1$ & $0 / 3$ & $0 / 1$ & $0 / 10$ & $0 / 17$ & $0 / 8$ & -- & $0 / 1$ \\
\hline \multirow[t]{2}{*}{ Uruguay } & Mar-72 & $9 / 5$ & $9 / 8$ & $0 / 1$ & -- & $9 / 6$ & $24 / 0$ & $24 / 0$ & $9 / 0$ & $9 / 6$ & $9 / 15$ & $24 / 0$ & $24 / 0$ & $24 / 0$ & $9 / 0$ \\
\hline & Nov- 82 & $0 / 8$ & $0 / 4$ & 0/19 & -- & $0 / 8$ & $0 / 13$ & $24 / 0$ & $6 / 9$ & $0 / 8$ & $0 / 9$ & $0 / 0$ & $0 / 0$ & $0 / 0$ & $0 / 0$ \\
\hline \multirow[t]{3}{*}{ Venezuela } & Mar-84 & $0 / 3$ & $0 / 5$ & $0 / 22$ & $0 / 4$ & $0 / 6$ & $0 / 8$ & $24 / 0$ & $0 / 2$ & $0 / 6$ & $0 / 11$ & $23 / 0$ & $23 / 0$ & $23 / 0$ & $0 / 0$ \\
\hline & Dec-86 & $0 / 2$ & $0 / 12$ & $0 / 0$ & $0 / 0$ & $0 / 3$ & $0 / 0$ & $0 / 3$ & $0 / 9$ & $0 / 2$ & $0 / 3$ & $0 / 0$ & $0 / 0$ & $0 / 0$ & $0 / 0$ \\
\hline & Mar-89 & $0 / 12$ & $0 / 0$ & $0 / 0$ & $0 / 8$ & $0 / 2$ & $0 / 2$ & $0 / 7$ & $0 / 4$ & $0 / 8$ & $0 / 4$ & $0 / 0$ & $0 / 0$ & $0 / 0$ & $0 / 4$ \\
\hline \multirow[t]{5}{*}{ Chile } & Jul-71 & $17 / 0$ & $17 / 4$ & $5 / 18$ & $24 / 0$ & $17 / 0$ & $17 / 0$ & $24 / 0$ & $17 / 0$ & $17 / 3$ & $17 / 4$ & $24 / 0$ & $24 / 0$ & $24 / 0$ & $17 / 1$ \\
\hline & Sep-72 & $0 / 12$ & $0 / 8$ & $0 / 0$ & $14 / 0$ & $0 / 0$ & $0 / 1$ & $14 / 0$ & $0 / 1$ & $0 / 3$ & $0 / 13$ & $14 / 0$ & $14 / 0$ & $14 / 0$ & $0 / 2$ \\
\hline & May-73 & $0 / 3$ & $0 / 1$ & $0 / 4$ & $8 / 0$ & $0 / 0$ & $0 / 3$ & $8 / 0$ & $0 / 0$ & $0 / 7$ & $0 / 3$ & $8 / 0$ & $8 / 0$ & $8 / 0$ & $0 / 3$ \\
\hline & Dec-74 & $0 / 2$ & $0 / 1$ & $0 / 0$ & $19 / 0$ & $0 / 0$ & $0 / 8$ & $18 / 0$ & $0 / 0$ & $0 / 1$ & $0 / 3$ & $19 / 0$ & $19 / 0$ & $19 / 0$ & $0 / 6$ \\
\hline & Jul-85 & $0 / 0$ & $0 / 1$ & $0 / 0$ & 0/11 & $0 / 7$ & $0 / 0$ & $0 / 0$ & $0 / 0$ & $0 / 0$ & $0 / 0$ & $0 / 2$ & $0 / 1$ & $0 / 12$ & $0 / 0$ \\
\hline
\end{tabular}




\begin{tabular}{|c|c|c|c|c|c|c|c|c|c|c|c|c|c|c|c|}
\hline \multicolumn{16}{|c|}{ Appendix Table A continued } \\
\hline Country & $\begin{array}{l}\text { Crisis } \\
\text { Dates }\end{array}$ & Reserves & Exports & $\begin{array}{l}\text { Real } \\
\text { Exchange } \\
\text { Rates }\end{array}$ & $\begin{array}{l}\text { Index of } \\
\text { Equity } \\
\text { Prices }\end{array}$ & $\begin{array}{l}\text { Commercial } \\
\text { Bank } \\
\text { Deposits }\end{array}$ & $\begin{array}{l}\text { Output } \\
\text { Index }\end{array}$ & $\begin{array}{l}\text { Excess } \\
\text { M1 } \\
\text { Balances }\end{array}$ & M2 Mult. & $\begin{array}{l}\text { M2 to } \\
\text { Reserves }^{2}\end{array}$ & $\begin{array}{l}\text { Domestic } \\
\text { credit to } \\
\text { GDP }\end{array}$ & $\begin{array}{l}\text { Real } \\
\text { Interest } \\
\text { Rate }\end{array}$ & $\begin{array}{l}\text { Real Interest } \\
\text { Differential }\end{array}$ & $\begin{array}{l}\text { Lending } \\
\text { /Deposit }\end{array}$ & Imports \\
\hline & & $\mathrm{mv} / \mathrm{sig}$ & $\mathrm{mv} / \mathrm{sig}$ & $\mathrm{mv} / \mathrm{sig}$ & $\mathrm{mv} / \mathrm{sig}$ & $\mathrm{mv} / \mathrm{sig}$ & $\mathrm{mv} / \mathrm{sig}$ & $\mathrm{mv} / \mathrm{sig}$ & $\mathrm{mv} / \mathrm{sig}$ & $\mathrm{mv} / \mathrm{sig}$ & $\mathrm{mv} / \mathrm{sig}$ & $\mathrm{mv} / \mathrm{sig}$ & $\mathrm{mv} / \mathrm{sig}$ & $\mathrm{mv} / \mathrm{sig}$ & $\mathrm{mv} / \mathrm{sig}$ \\
\hline \multirow[t]{4}{*}{ Norway } & Jun-73 & $0 / 0$ & $0 / 0$ & $0 / 0$ & $0 / 8$ & $0 / 0$ & $0 / 1$ & $24 / 0$ & $0 / 2$ & $0 / 0$ & $0 / 10$ & $24 / 0$ & $24 / 0$ & $24 / 0$ & $0 / 2$ \\
\hline & Feb-78 & $0 / 1$ & $0 / 1$ & $0 / 0$ & $0 / 12$ & $0 / 0$ & $0 / 6$ & $24 / 0$ & $0 / 2$ & $0 / 2$ & $13 / 10$ & $24 / 0$ & $24 / 0$ & $24 / 0$ & $0 / 4$ \\
\hline & May-86 & $0 / 0$ & $0 / 3$ & $0 / 9$ & $0 / 0$ & $0 / 0$ & $0 / 4$ & $24 / 0$ & $1 / 7$ & $1 / 0$ & $0 / 0$ & $0 / 1$ & $0 / 0$ & $0 / 0$ & $0 / 5$ \\
\hline & Nov-92 & $0 / 7$ & $0 / 4$ & $0 / 1$ & $0 / 6$ & $0 / 14$ & $0 / 4$ & $24 / 0$ & $0 / 3$ & $0 / 5$ & $0 / 0$ & $0 / 5$ & $0 / 0$ & $0 / 0$ & $0 / 0$ \\
\hline \multirow[t]{2}{*}{ Greece } & Jan-83 & $0 / 13$ & $0 / 7$ & $0 / 0$ & -- & $0 / 0$ & $0 / 10$ & $0 / 2$ & $0 / 0$ & $0 / 10$ & $0 / 16$ & $0 / 0$ & $0 / 0$ & $0 / 4$ & $0 / 4$ \\
\hline & Oct-85 & $0 / 0$ & $0 / 1$ & $0 / 0$ & -- & $0 / 0$ & $0 / 2$ & $0 / 0$ & $0 / 3$ & $0 / 0$ & $0 / 0$ & $0 / 0$ & $0 / 0$ & $0 / 0$ & $0 / 1$ \\
\hline \multirow[t]{2}{*}{ India } & Jul-91 & $0 / 9$ & $0 / 0$ & $0 / 0$ & $0 / 0$ & $0 / 5$ & $0 / 1$ & $0 / 0$ & $0 / 0$ & $0 / 9$ & $0 / 0$ & -- & -- & -- & $0 / 0$ \\
\hline & Mar-93 & $0 / 5$ & $0 / 2$ & $0 / 0$ & $0 / 1$ & $0 / 2$ & $0 / 10$ & $0 / 1$ & $0 / 8$ & $0 / 4$ & $0 / 0$ & -- & -- & -- & $0 / 1$ \\
\hline Pakistan & May-72 & $7 / 4$ & $7 / 0$ & $0 / 16$ & $11 / 12$ & $7 / 4$ & $24 / 0$ & $24 / 0$ & $7 / 2$ & $7 / 4$ & $7 / 7$ & -- & -- & -- & $7 / 0$ \\
\hline Sri Lanka & Nov-77 & $0 / 3$ & $0 / 5$ & $0 / 0$ & -- & $0 / 1$ & -- & $0 / 0$ & $0 / 4$ & $0 / 0$ & $0 / 11$ & $24 / 0$ & $24 / 0$ & $24 / 0$ & $0 / 0$ \\
\hline \multirow[t]{4}{*}{ Singapore } & Dec-70 & $24 / 0$ & $24 / 0$ & $12 / 0$ & $24 / 0$ & $24 / 0$ & $24 / 0$ & $24 / 0$ & $24 / 0$ & $24 / 0$ & $24 / 0$ & $24 / 0$ & $24 / 0$ & $24 / 0$ & $24 / 0$ \\
\hline & Jul-75 & $0 / 1$ & $0 / 5$ & $0 / 23$ & $24 / 0$ & $0 / 0$ & $24 / 0$ & $24 / 0$ & $0 / 4$ & $0 / 0$ & $0 / 2$ & $24 / 0$ & $24 / 0$ & $24 / 0$ & $0 / 15$ \\
\hline & Nov-78 & $0 / 0$ & $0 / 0$ & $0 / 1$ & $24 / 0$ & $0 / 7$ & $24 / 0$ & $24 / 0$ & $0 / 0$ & $0 / 0$ & $1 / 2$ & $1 / 0$ & $1 / 5$ & $13 / 0$ & $0 / 0$ \\
\hline & Mar- 80 & $0 / 2$ & $0 / 0$ & $0 / 0$ & $16 / 0$ & $0 / 1$ & $16 / 0$ & $16 / 0$ & $0 / 0$ & $0 / 2$ & $1 / 0$ & $0 / 4$ & $0 / 0$ & $0 / 0$ & $0 / 5$ \\
\hline \multicolumn{16}{|l|}{ Sum. Statistics } \\
\hline crisis called & 0.66 & 0.72 & 0.44 & 0.62 & 0.35 & 0.68 & 0.52 & 0.63 & 0.61 & 0.67 & 0.53 & 0.26 & 0.28 & 0.52 & 0.45 \\
\hline $\begin{array}{l}\text { noise-to-signal } \\
\text { ratio }\end{array}$ & 0.53 & 0.60 & 0.26 & 0.57 & 0.94 & 0.59 & 0.55 & 0.86 & 0.52 & 0.75 & 0.66 & 1.00 & 2.75 & 0.87 & 0.58 \\
\hline critical region & 0.10 & 0.10 & 0.10 & 0.20 & 0.10 & 0.14 & 0.10 & 0.15 & 0.10 & 0.20 & 0.20 & 0.10 & 0.20 & 0.10 & 0.10 \\
\hline \# of Countries & 28 & 28 & 28 & 17 & 25 & 21 & 24 & 28 & 28 & 27 & 23 & 23 & 18 & 28 & 28 \\
\hline $\begin{array}{l}\text { Number of } \\
\text { Crises }\end{array}$ & 89 & 89 & 91 & 48 & 75 & 66 & 44 & 83 & 83 & 72 & 60 & 58 & 43 & 89 & 89 \\
\hline
\end{tabular}




\begin{tabular}{|c|c|c|c|c|c|c|c|c|}
\hline Country & Crisis Dates & US Growth & G7 Growth & $\begin{array}{l}\text { Change in US Interest } \\
\text { Rates }\end{array}$ & Change in Oil Prices & Level of M2/Reserves & $\begin{array}{l}\text { STD/Reserves } \\
\text { (Change) }\end{array}$ & STD/Reserves (Level) \\
\hline & & $\mathrm{mv} / \mathrm{sig}$ & $\mathrm{mv} / \mathrm{sig}$ & $\mathrm{mv} / \mathrm{sig}$ & $\mathrm{mv} / \mathrm{sig}$ & $\mathrm{mv} / \mathrm{sig}$ & $\mathrm{mv} / \mathrm{sig}$ & $\mathrm{mv} / \mathrm{sig}$ \\
\hline \multirow[t]{4}{*}{ Argentina } & Mar-75 & $0 / 6$ & $0 / 7$ & $0 / 6$ & $0 / 12$ & $0 / 9$ & $24 / 0$ & $24 / 0$ \\
\hline & Jul-82 & $0 / 8$ & $0 / 11$ & $0 / 6$ & $0 / 0$ & $0 / 0$ & $24 / 0$ & $24 / 0$ \\
\hline & Apr-89 & $0 / 0$ & $0 / 0$ & $0 / 3$ & $0 / 1$ & $0 / 0$ & $1 / 8$ & $0 / 11$ \\
\hline & Dec-89 & $0 / 0$ & $0 / 0$ & $0 / 0$ & $0 / 0$ & $0 / 0$ & $0 / 0$ & $0 / 1$ \\
\hline \multirow[t]{3}{*}{ Bolivia } & Nov-82 & $0 / 10$ & $0 / 11$ & $0 / 6$ & $0 / 0$ & $0 / 11$ & $24 / 0$ & $24 / 0$ \\
\hline & Nov-83 & $0 / 1$ & $0 / 1$ & $0 / 0$ & $0 / 0$ & $0 / 0$ & $12 / 0$ & $12 / 0$ \\
\hline & Sep-85 & $0 / 0$ & $0 / 0$ & $0 / 0$ & $0 / 0$ & $0 / 0$ & $22 / 0$ & $22 / 0$ \\
\hline \multirow[t]{4}{*}{ Brazil } & Sep-82 & $0 / 8$ & $0 / 11$ & $0 / 6$ & $0 / 0$ & $0 / 0$ & $24 / 0$ & $24 / 0$ \\
\hline & Mar-90 & $0 / 0$ & $0 / 0$ & $0 / 3$ & $0 / 0$ & $0 / 7$ & $0 / 1$ & $0 / 1$ \\
\hline & Nov-90 & $0 / 0$ & $0 / 0$ & $0 / 0$ & $0 / 3$ & $0 / 7$ & $0 / 1$ & $0 / 0$ \\
\hline & Sep-91 & $0 / 6$ & $0 / 0$ & $0 / 0$ & $0 / 0$ & $0 / 8$ & $0 / 2$ & $0 / 0$ \\
\hline Colombia & Jan-85 & $0 / 0$ & $0 / 0$ & $0 / 0$ & $0 / 0$ & $10 / 3$ & $24 / 0$ & $24 / 0$ \\
\hline \multirow[t]{3}{*}{ Denmark } & Jun-73 & $0 / 0$ & $0 / 0$ & $0 / 2$ & $0 / 0$ & $0 / 5$ & -- & -- \\
\hline & Nov-79 & $0 / 0$ & $0 / 0$ & $0 / 8$ & $0 / 9$ & $0 / 0$ & -- & -- \\
\hline & Aug-93 & $0 / 0$ & $0 / 0$ & $0 / 0$ & $0 / 0$ & $0 / 0$ & -- & -- \\
\hline \multirow[t]{4}{*}{ Finland } & Jun-73 & $0 / 0$ & $0 / 0$ & $0 / 2$ & $0 / 0$ & $0 / 0$ & -- & -- \\
\hline & Apr-77 & $0 / 2$ & $0 / 4$ & $0 / 0$ & $0 / 0$ & $0 / 19$ & -- & -- \\
\hline & Oct- 82 & $0 / 9$ & $0 / 11$ & $0 / 6$ & $0 / 0$ & $0 / 1$ & -- & -- \\
\hline & Sep-92 & $0 / 6$ & $0 / 0$ & $0 / 0$ & $0 / 2$ & $0 / 0$ & -- & -- \\
\hline & & & & & & & & \\
\hline
\end{tabular}




\begin{tabular}{|c|c|c|c|c|c|c|c|c|}
\hline \multicolumn{9}{|c|}{ Appendix Table A continued } \\
\hline Country & Crisis Dates & US Growth & G7 Growth & $\begin{array}{l}\text { Change in US Interest } \\
\text { Rates }\end{array}$ & Change in Oil Prices & Level of M2/Reserves & $\begin{array}{l}\text { STD/Reserves } \\
\text { (Change) }\end{array}$ & STD/Reserves (Level) \\
\hline & & $\mathrm{mv} / \mathrm{sig}$ & $\mathrm{mv} / \mathrm{sig}$ & $\mathrm{mv} / \mathrm{sig}$ & $\mathrm{mv} / \mathrm{sig}$ & $\mathrm{mv} / \mathrm{sig}$ & $\mathrm{mv} / \mathrm{sig}$ & $\mathrm{mv} / \mathrm{sig}$ \\
\hline \multirow[t]{3}{*}{ Indonesia } & Nov-78 & $0 / 0$ & $0 / 0$ & $0 / 0$ & $0 / 0$ & $0 / 0$ & $24 / 0$ & $24 / 0$ \\
\hline & Apr-83 & $0 / 11$ & $0 / 10$ & $0 / 5$ & $0 / 0$ & $0 / 1$ & $24 / 0$ & $24 / 0$ \\
\hline & Sep-86 & $0 / 0$ & $0 / 0$ & $0 / 0$ & $0 / 0$ & $0 / 0$ & $24 / 0$ & $20 / 0$ \\
\hline \multirow[t]{4}{*}{ Israel } & Nov-74 & $0 / 2$ & $0 / 3$ & $0 / 6$ & $0 / 11$ & $0 / 0$ & $24 / 0$ & $24 / 0$ \\
\hline & Nov-77 & $0 / 0$ & $0 / 0$ & $0 / 0$ & $0 / 0$ & $0 / 0$ & $24 / 0$ & $24 / 0$ \\
\hline & Oct-83 & $0 / 11$ & $0 / 10$ & $0 / 0$ & $0 / 0$ & $0 / 0$ & $24 / 0$ & $24 / 0$ \\
\hline & Jul-84 & $0 / 0$ & $0 / 0$ & $0 / 0$ & $0 / 0$ & $0 / 0$ & $9 / 0$ & $9 / 0$ \\
\hline \multirow[t]{3}{*}{ Korea } & Jun-71 & $18 / 0$ & $20 / 0$ & $18 / 0$ & $18 / 0$ & $6 / 0$ & $24 / 0$ & $24 / 0$ \\
\hline & Dec-74 & $0 / 3$ & $0 / 4$ & $0 / 6$ & $0 / 12$ & $0 / 5$ & $24 / 0$ & $24 / 0$ \\
\hline & Jan-80 & $0 / 0$ & $0 / 0$ & $0 / 10$ & $0 / 11$ & $0 / 0$ & $24 / 0$ & $24 / 0$ \\
\hline \multirow[t]{5}{*}{ Malaysia } & Nov-73 & $0 / 0$ & $0 / 0$ & $0 / 6$ & $0 / 0$ & $0 / 0$ & $24 / 0$ & $24 / 0$ \\
\hline & Nov-78 & $0 / 0$ & $0 / 0$ & $0 / 0$ & $0 / 0$ & $0 / 0$ & $24 / 0$ & $24 / 0$ \\
\hline & Mar-80 & $0 / 0$ & $0 / 0$ & $0 / 12$ & $0 / 13$ & $0 / 0$ & $16 / 0$ & $16 / 0$ \\
\hline & Feb-85 & $0 / 0$ & $0 / 0$ & $0 / 0$ & $0 / 0$ & $0 / 19$ & $24 / 0$ & $24 / 0$ \\
\hline & Dec-92 & $0 / 6$ & $0 / 0$ & $0 / 0$ & $0 / 0$ & $0 / 0$ & $0 / 2$ & $0 / 0$ \\
\hline \multirow[t]{4}{*}{ Mexico } & Sep-76 & $0 / 9$ & $0 / 1$ & $0 / 0$ & $0 / 3$ & $0 / 0$ & $24 / 0$ & $24 / 0$ \\
\hline & Feb-82 & $0 / 4$ & $0 / 7$ & $0 / 8$ & $0 / 1$ & $0 / 19$ & $24 / 0$ & $24 / 0$ \\
\hline & Dec-82 & $0 / 10$ & $0 / 10$ & $0 / 0$ & $0 / 0$ & $0 / 8$ & $10 / 0$ & $10 / 0$ \\
\hline & Dec-94 & $0 / 0$ & $0 / 0$ & $0 / 0$ & $0 / 0$ & $0 / 0$ & $0 / 1$ & $0 / 1$ \\
\hline \multirow[t]{2}{*}{ Peru } & Jun-76 & $0 / 9$ & $0 / 2$ & $0 / 0$ & $0 / 6$ & $0 / 7$ & $24 / 0$ & $24 / 0$ \\
\hline & Oct- 87 & $0 / 0$ & $0 / 0$ & $0 / 0$ & $0 / 1$ & $0 / 0$ & $19 / 1$ & $7 / 0$ \\
\hline
\end{tabular}




\begin{tabular}{|c|c|c|c|c|c|c|c|c|}
\hline \multicolumn{9}{|c|}{ Appendix Table A continued } \\
\hline Country & Crisis Dates & US Growth & G7 Growth & $\begin{array}{l}\text { Change in US Interest } \\
\text { Rates }\end{array}$ & Change in Oil Prices & Level of M2/Reserves & $\begin{array}{l}\text { STD/Reserves } \\
\text { (Change) }\end{array}$ & STD/Reserves (Level) \\
\hline & & $\mathrm{mv} / \mathrm{sig}$ & $\mathrm{mv} / \mathrm{sig}$ & $\mathrm{mv} / \mathrm{sig}$ & $\mathrm{mv} / \mathrm{sig}$ & $\mathrm{mv} / \mathrm{sig}$ & $\mathrm{mv} / \mathrm{sig}$ & $\mathrm{mv} / \mathrm{sig}$ \\
\hline \multirow[t]{3}{*}{ Philippines } & Oct-83 & $0 / 11$ & $0 / 10$ & $0 / 0$ & $0 / 0$ & $4 / 4$ & $24 / 0$ & $24 / 0$ \\
\hline & Jun-84 & $0 / 0$ & $0 / 0$ & $0 / 0$ & $0 / 0$ & $7 / 0$ & $8 / 0$ & $8 / 0$ \\
\hline & Feb-86 & $0 / 0$ & $0 / 0$ & $0 / 0$ & $0 / 0$ & $18 / 1$ & $20 / 0$ & $20 / 0$ \\
\hline \multirow[t]{4}{*}{ Portugal } & Mar-76 & $0 / 9$ & $0 / 12$ & $0 / 0$ & $0 / 9$ & $24 / 0$ & $24 / 0$ & $24 / 0$ \\
\hline & Feb-77 & $0 / 0$ & $0 / 0$ & $0 / 0$ & $0 / 0$ & $8 / 3$ & $11 / 0$ & $11 / 0$ \\
\hline & Jun-82 & $0 / 8$ & $0 / 11$ & $0 / 6$ & $0 / 0$ & $0 / 5$ & $24 / 0$ & $24 / 0$ \\
\hline & Jun-83 & $0 / 6$ & $0 / 6$ & $0 / 0$ & $0 / 0$ & $0 / 2$ & $12 / 0$ & $12 / 0$ \\
\hline \multirow[t]{4}{*}{ South Africa } & Sep-75 & $0 / 9$ & $0 / 12$ & $0 / 1$ & $0 / 12$ & $16 / 0$ & $24 / 0$ & $24 / 0$ \\
\hline & Jul-84 & $0 / 5$ & $0 / 5$ & $0 / 0$ & $0 / 0$ & $16 / 1$ & $24 / 0$ & $24 / 0$ \\
\hline & Aug-85 & $0 / 0$ & $0 / 0$ & $0 / 0$ & $0 / 0$ & $9 / 2$ & $13 / 0$ & $13 / 0$ \\
\hline & May-86 & $0 / 0$ & $0 / 0$ & $0 / 0$ & $0 / 0$ & $6 / 1$ & $9 / 0$ & $9 / 0$ \\
\hline \multirow[t]{6}{*}{ Spain } & Jun-73 & $0 / 0$ & 0/0 & $0 / 2$ & $0 / 0$ & $24 / 0$ & -- & -- \\
\hline & Feb-76 & $0 / 9$ & $0 / 12$ & $0 / 0$ & $0 / 10$ & $24 / 0$ & -- & -- \\
\hline & Jul-77 & $0 / 0$ & $0 / 0$ & $0 / 0$ & $0 / 0$ & $17 / 0$ & -- & -- \\
\hline & Mar-83 & $0 / 11$ & $0 / 10$ & $0 / 5$ & $0 / 0$ & $24 / 0$ & -- & -- \\
\hline & Sep-92 & $0 / 6$ & $0 / 0$ & $0 / 0$ & $0 / 2$ & $0 / 0$ & -- & -- \\
\hline & Mar-95 & $0 / 0$ & $0 / 0$ & $0 / 1$ & $0 / 0$ & $0 / 0$ & -- & -- \\
\hline \multirow[t]{4}{*}{ Sweden } & Aug-77 & $0 / 0$ & $0 / 0$ & $0 / 0$ & $0 / 0$ & $0 / 0$ & -- & -- \\
\hline & Sep-81 & $0 / 3$ & $0 / 7$ & $0 / 13$ & $0 / 6$ & $0 / 0$ & -- & -- \\
\hline & Oct-82 & $0 / 9$ & $0 / 8$ & $0 / 0$ & $0 / 0$ & $0 / 0$ & -- & -- \\
\hline & Nov-92 & $0 / 6$ & $0 / 0$ & $0 / 0$ & $0 / 0$ & $0 / 0$ & -- & -- \\
\hline
\end{tabular}




\begin{tabular}{|c|c|c|c|c|c|c|c|c|}
\hline \multicolumn{9}{|c|}{ Appendix Table A continued } \\
\hline Country & Crisis Dates & US Growth & G7 Growth & $\begin{array}{l}\text { Change in US Interest } \\
\text { Rates }\end{array}$ & Change in Oil Prices & Level of M2/Reserves & $\begin{array}{l}\text { STD/Reserves } \\
\text { (Change) }\end{array}$ & STD/Reserves (Level) \\
\hline & & $\mathrm{mv} / \mathrm{sig}$ & $\mathrm{mv} / \mathrm{sig}$ & $\mathrm{mv} / \mathrm{sig}$ & $\mathrm{mv} / \mathrm{sig}$ & $\mathrm{mv} / \mathrm{sig}$ & $\mathrm{mv} / \mathrm{sig}$ & $\mathrm{mv} / \mathrm{sig}$ \\
\hline \multirow[t]{3}{*}{ Thailand } & Nov-78 & $0 / 0$ & $0 / 0$ & $0 / 0$ & $0 / 0$ & $0 / 0$ & $24 / 0$ & $24 / 0$ \\
\hline & Jul-81 & $0 / 3$ & $0 / 7$ & $0 / 11$ & $0 / 8$ & $0 / 1$ & $24 / 0$ & $24 / 0$ \\
\hline & Nov-84 & $0 / 1$ & $0 / 1$ & $0 / 0$ & $0 / 0$ & $0 / 21$ & $24 / 0$ & $24 / 0$ \\
\hline \multirow[t]{3}{*}{ Turkey } & Aug-70 & $24 / 0$ & $24 / 0$ & $24 / 0$ & $24 / 0$ & $16 / 8$ & $24 / 0$ & $24 / 0$ \\
\hline & Jan-80 & $0 / 0$ & $0 / 0$ & $0 / 10$ & $0 / 11$ & $0 / 9$ & $24 / 0$ & $24 / 0$ \\
\hline & Mar-94 & $0 / 0$ & $0 / 0$ & $0 / 0$ & $0 / 0$ & $0 / 0$ & $0 / 3$ & $0 / 0$ \\
\hline \multirow[t]{2}{*}{ Uruguay } & Mar-72 & $9 / 0$ & $11 / 0$ & $9 / 0$ & $9 / 0$ & $0 / 20$ & $24 / 0$ & $24 / 0$ \\
\hline & Nov-82 & $0 / 10$ & $0 / 11$ & $0 / 6$ & $0 / 0$ & $0 / 8$ & $24 / 0$ & $24 / 0$ \\
\hline \multirow[t]{3}{*}{ Venezuela } & Mar-84 & $0 / 9$ & $0 / 9$ & $0 / 0$ & $0 / 0$ & $0 / 14$ & $24 / 0$ & $24 / 0$ \\
\hline & Dec-86 & $0 / 0$ & $0 / 0$ & $0 / 0$ & $0 / 0$ & $0 / 0$ & $24 / 0$ & $17 / 4$ \\
\hline & Mar-89 & $0 / 0$ & $0 / 0$ & $0 / 2$ & $0 / 1$ & $0 / 8$ & $2 / 7$ & $0 / 6$ \\
\hline \multirow[t]{5}{*}{ Chile } & Jul-71 & $17 / 0$ & $19 / 0$ & $17 / 0$ & $17 / 0$ & $5 / 4$ & $24 / 0$ & $24 / 0$ \\
\hline & Sep-72 & $0 / 0$ & $0 / 0$ & $0 / 0$ & $0 / 0$ & $0 / 9$ & $14 / 0$ & $14 / 0$ \\
\hline & May-73 & $0 / 0$ & $0 / 0$ & $0 / 1$ & $0 / 0$ & $0 / 8$ & $8 / 0$ & $8 / 0$ \\
\hline & Dec-74 & $0 / 3$ & $0 / 4$ & $0 / 5$ & $0 / 12$ & $0 / 5$ & $19 / 0$ & $19 / 0$ \\
\hline & Jul-85 & $0 / 0$ & $0 / 0$ & $0 / 0$ & $0 / 0$ & $0 / 0$ & $24 / 0$ & $24 / 0$ \\
\hline \multirow[t]{4}{*}{ Norway } & Jun-73 & $0 / 0$ & $0 / 0$ & $0 / 2$ & $0 / 0$ & $0 / 15$ & -- & -- \\
\hline & Feb-78 & $0 / 0$ & $0 / 0$ & $0 / 0$ & $0 / 0$ & $0 / 2$ & -- & -- \\
\hline & May-86 & $0 / 0$ & $0 / 0$ & $0 / 0$ & $0 / 0$ & $1 / 0$ & -- & -- \\
\hline & Nov-92 & $0 / 6$ & $0 / 0$ & $0 / 0$ & $0 / 0$ & $0 / 0$ & -- & -- \\
\hline
\end{tabular}




\begin{tabular}{|c|c|c|c|c|c|c|c|c|}
\hline \multicolumn{9}{|c|}{ Appendix Table A continued } \\
\hline Country & Crisis Dates & US Growth & G7 Growth & $\begin{array}{l}\text { Change in US Interest } \\
\text { Rates }\end{array}$ & Change in Oil Prices & Level of M2/Reserves & $\begin{array}{l}\text { STD/Reserves } \\
\text { (Change) }\end{array}$ & STD/Reserves (Level) \\
\hline & & $\mathrm{mv} / \mathrm{sig}$ & $\mathrm{mv} / \mathrm{sig}$ & $\mathrm{mv} / \mathrm{sig}$ & $\mathrm{mv} / \mathrm{sig}$ & $\mathrm{mv} / \mathrm{sig}$ & $\mathrm{mv} / \mathrm{sig}$ & $\mathrm{mv} / \mathrm{sig}$ \\
\hline \multirow[t]{2}{*}{ Greece } & Jan-83 & $0 / 11$ & $0 / 10$ & $0 / 5$ & $0 / 0$ & $0 / 10$ & $24 / 0$ & $24 / 0$ \\
\hline & Oct-85 & $0 / 0$ & $0 / 0$ & $0 / 0$ & $0 / 0$ & $0 / 5$ & $24 / 0$ & $24 / 0$ \\
\hline \multirow[t]{2}{*}{ India } & Jul-91 & $0 / 3$ & $0 / 0$ & $0 / 0$ & $0 / 3$ & $0 / 24$ & $0 / 7$ & $0 / 7$ \\
\hline & Mar-93 & $0 / 3$ & $0 / 0$ & $0 / 0$ & $0 / 0$ & $0 / 11$ & $0 / 4$ & $0 / 5$ \\
\hline Pakistan & May-72 & $7 / 0$ & $9 / 0$ & $7 / 0$ & $7 / 0$ & $0 / 3$ & $24 / 0$ & $24 / 0$ \\
\hline Sri Lanka & Nov-77 & $0 / 0$ & $0 / 0$ & $0 / 0$ & $0 / 0$ & $0 / 2$ & $24 / 0$ & $24 / 0$ \\
\hline \multirow[t]{4}{*}{ Singapore } & Dec-70 & $24 / 0$ & $24 / 0$ & $24 / 0$ & $24 / 0$ & $12 / 0$ & $24 / 0$ & $24 / 0$ \\
\hline & Jul-75 & $0 / 9$ & $0 / 11$ & $0 / 3$ & $0 / 12$ & $0 / 0$ & $24 / 0$ & $24 / 0$ \\
\hline & Nov-78 & $0 / 0$ & $0 / 0$ & $0 / 0$ & $0 / 0$ & $0 / 0$ & $24 / 0$ & $24 / 0$ \\
\hline & Mar-80 & $0 / 0$ & $0 / 0$ & $0 / 12$ & $0 / 13$ & $0 / 0$ & $16 / 0$ & $16 / 0$ \\
\hline \multicolumn{9}{|l|}{ Summary Statistics } \\
\hline percent of crisis called & & 0.45 & 0.36 & 0.37 & 0.28 & 0.50 & 0.92 & 0.57 \\
\hline noise-to-signal ratio & & 0.58 & 0.58 & 0.97 & 0.99 & 0.47 & 0.40 & 0.47 \\
\hline Size of critical region & & 0.10 & 0.1 & 0.10 & 0.10 & 0.12 & 0.12 & 0.12 \\
\hline Number of Countries & & 28 & 28 & 28 & 28 & 28 & 8 & 9 \\
\hline Number of Crises & & 89 & 89 & 89 & 89 & 86 & 12 & 14 \\
\hline
\end{tabular}

